
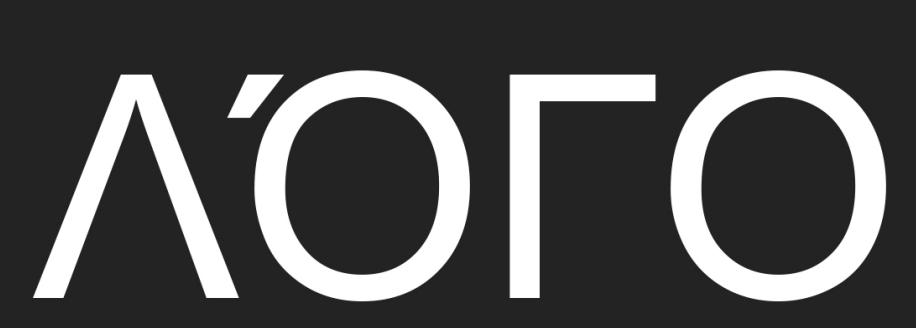

\title{
COLLECTION OF SCIENTIFIC PAPERS
}

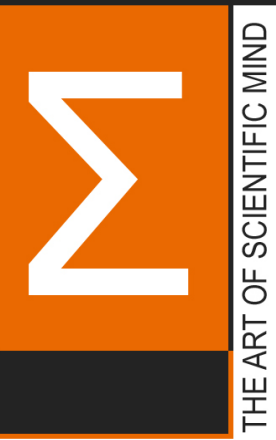

WITH PROCEEDINGS OF THE INTERNATIONAL SCIENTIFIC AND PRACTICAL CONFERENCE

\section{SCIENTIFIC DISCOVERIES: PROJECTS, STRATEGIES AND DEVELOPMENT}

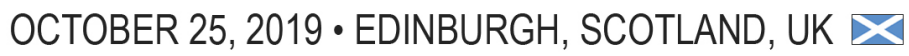

\section{VOLUME 1}

DOI 10.36074/25.10.2019.v1

ISBN 978-617-7171-83-5

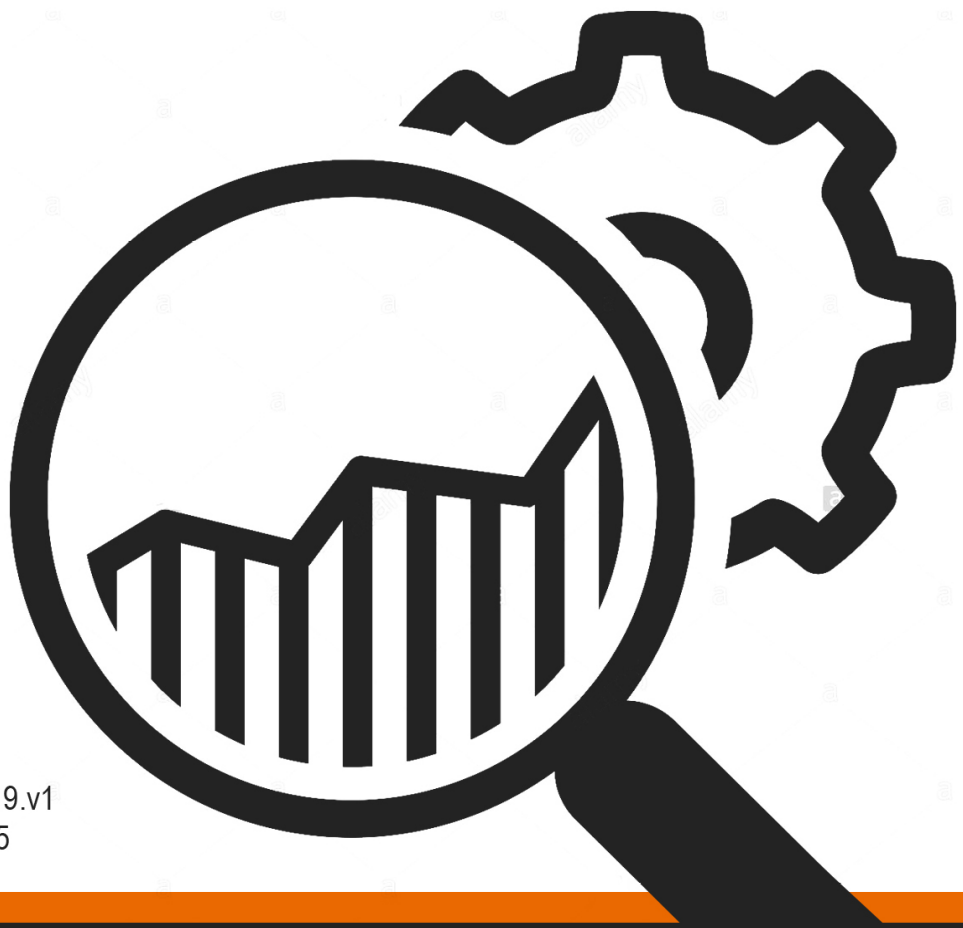



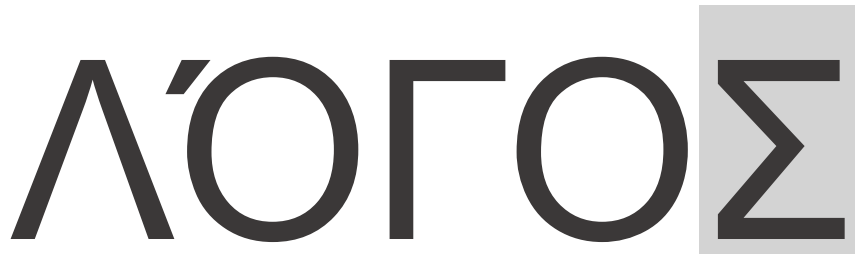

COLLECTION OF SCIENTIFIC PAPERS

WITH PROCEEDINGS OF THE INTERNATIONAL SCIENTIFIC AND PRACTICAL CONFERENCE

«SCIENTIFIC DISCOVERIES: PROJECTS, STRATEGIES AND DEVELOPMENT»

OCTOBER 25, 2019

\section{VOLUME 1}

Edinburgh • Scotland, UK 
S 30

Chairman of the Organizing Committee: Holdenblat M.

Responsible for the layout: Kazmina N.

Responsible designer: Bondarenko I.

S 30 Scientific discoveries: projects, strategies and development: Collection of scientific papers «^ОГО $\Sigma$ » with Proceedings of the International Scientific and Practical Conference (Vol. 1), October 25, 2019. Edinburgh, UK: European Scientific Platform.

ISBN 978-617-7171-83-5

DOI 10.36074/25.05.2019.v1

Papers of participants of the International Multidisciplinary Scientific and Practical Conference «Scientific discoveries: projects, strategies and development», held in Edinburgh, October 25, 2019, are presented in the collection of scientific papers.

The conference is included in the catalog of International Scientific Conferences, approved by ResearchBib and certified by Euro Science Certification Group (SCC-2000).

Conference proceedings are publicly available under terms of the Creative Commons Attribution 4.0 International License (CC BY 4.0).

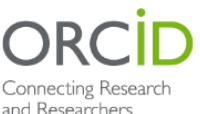

and Researchers

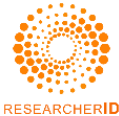

RESEARCHERID
Bibliographic descriptions of the conference proceedings are available for indexation by ORCID, Publons, Google Scholar, ets.

(C) Participants of the conference, 2019 


\section{CONTENT}

\section{SECTION I. ECONOMICS}

CLASSIFICATION CRITERIA OF STRUCTURE CATEGORIES OF SERVICE SECTOR

Stolyarchuk V.

ENTWICKLUNG VON AUSLÄNDISCHEN DIREKTINVESTITIONEN IN DER UKRAINE

Kotsur S.

FEATURES OF FORMATION OF FINANCIAL POTENTIAL OF THE ENTERPRISE

Pecheniuk A., Dakhno V.

INTEGRAL INDICATOR OF INNOVATION SECURITY AS A TOOL FOR ASSESSING THE INNOVATIVE DEVELOPMENT OF COUNTRIES

Gnidina V.

PROFESSIONAL EDUCATION IN UKRAINE IN CONDITIONS OF THE GLOBAL ECONOMY

Denchyk I.

«БЛАКИТНИЙ ОКЕАН»: НЕОБХІДНІСТЬ ЧИ ПРИВІЛЁ̈?

Гуняга Н.O.

ГРУПУВАННЯ ВИДІВ ТА ВИЗНАЧЕННЯ КРИТЕРІЇВ ЕКОНОМІЧНОГО ЗРОСТАННЯ ПІДПРИЕМСТВ

Науково-дослідна група:

Ємельянов О.Ю., Петрушка К.І., Товкан О.Е.

ЕКОНОМІЧНА СУТНІСТЬ УПРАВЛІННЯ ДОХОДАМИ ДОМОГОСПОДАРСТВ ВІД ПІДПРИЕМНИЦЬКОЇ ДІЯЛЬНОСТІ

Перит I.O.

ЗАКОНОДАВЧЕ РЕГУЛЮВАННЯ ІНОЗЕМНОГО ІНВЕСТУВАННЯ В УКРӒ̈НІ

Псьота T.B.

ІНТЕЛЕКТУАЛЬНИЙ АНАЛІЗ ЯК МЕХАНІЗМ ВИЯВЛЕННЯ СХЕМНИХ ОПЕРАЦІЙ В УКРАЇНІ

Науково-дослідна група:

Кузьменко О.В., Бойко А.О., Яровенко Г.М., Доценко Т.В. 
4 - Scientific discoveries: projects, strategies and development $\bullet$ Volume 1

КОНКУРЕНТОСПРОМОЖНІСТЬ ПЕРСОНАЛУ ЯК ОСНОВНИЙ ЧИННИК ЕФЕКТИВНОЇ ДІЯЛЬНОСТІ ПІДПРИЕМСТВА

Ошийко А.А.

МАРКЕТИНГОВІ ІНТЕРНЕТ-ТЕХНОЛОГІЇ В АГРАРНОМУ СЕКТОРІ УКРАЇНИ

Рябчик А.B.

ОСОБЛИВОСТІ УПРАВЛІННЯ КАДРАМИ В СУЧАСНИХ УМОВАХ Захарова К.В.

ОЦІНКА СУЧАСНОГО СТАНУ ДЕРЖАВНОГО БОРГУ УКРАЇНИ Лаб'як Г.В., Томашевська А.М.

ПОГЛЯД НА ОБЛІКОВО-АНАЛІТИЧНЕ ЗАБЕЗПЕЧЕННЯ БІЗНЕСПЛАНУ

Болваненко Л.В., Сітарчук В.В.

УДОСКОНАЛЕННЯ

ІНФОРМАЦІЙНО-АНАЛІТИЧНОГО ЗАБЕЗПЕЧЕННЯ УПРАВЛІННЯ ЕКОНОМІЧНИМ ПОТЕНЦІАЛОМ ТА ЕКОНОМІЧНОЮ ПОТУЖНІСТЮ

Дзюба T.І.

ФОРМУВАННЯ АНТИКРИЗОВОЇ СТРАТЕГІЇ НА ОСНОВІ АНТИКРИЗОВОГО ПОТЕНЦІАЛУ ПІДПРИЕМСТВА

Шатайло O.A.

ШЛЯХИ ПІДВИЩЕННЯ КОНКУРЕНТОСПРОМОЖНОСТІ ПІДПРИЄМСТВА НА ПРИКЛАДІ КАВ'ЯРНІ «РАКЕТА КОФЕ»

Сітало Н.Г.

\section{SECTION II.}

AGRICULTURAL SCIENCES

ВИРОЩУВАННЯ РЕМОНТНИХ ТЕЛИЦЬ МЯСНОГО КОМОЛОГО СИМЕНТАЛУ ХУДОБИ НА ПІДСИСІ В УМОВАХ ПЕРЕДГІРСЬКОЇ ЗОНИ КАРПАТСЬКОГО РЕГІОНУ БУКОВИНИ

Науково-дослідна група:

Калинка А.К., Лесик О.Б., Казьмірук Л.В.

НОВА ПОПУЛЯЦІЯ СТАД М'ЯСНИХ СИМЕНТАЛІВ ХУДОБИ В КАРПАТСЬКОМУ РЕГІОНІ УКРАЇНИ

Науково-дослідна група:

Калинка А.К., Шпак Л.В., Петращук І.М. 
ОКУПАЦІЯ РЕГІОНАЛЬНОГО ЛАНДШАФТНОГО ПАРКУ «ЗНЕСІННЯ» КОМЕРЦІЙНОЮ АВТОСТОЯНКОЮ

Тарас У.М., Мекекечко М.В.

\section{SECTION III. \\ ENGINEERING AND IT}

APPLICATION OF SPLINES UNDER TENSION FOR SIMULATION OF THE STRESSED-DEFORMED CONDITION OF THE LINEAR PART OF THE MAIN PIPELINES

Nezamay B., Babchuk S.

BERRY POWDERS WITH A HIGH CONTENT OF PTEROSTILBENE AND RESVERATROL IN THE TECHNOLOGY OF CHOCOLATE FLOUR CONFECTIONERY

Polyvanov Ye., Kogan A.

COIL TUBING TECHNOLOGIES: A HISTORY OF DEVELOPMENT AND APPLICATION IN POLTAVA REGION

Dyachenko Yu., Zotova $\mathrm{H}$.

DIFFERENTIATION OF VULKAN API, OPENCL, AND OPENGL FOR RAY TRACING ALGORITHMS

Denysenko 0.

DYNAMIC MODEL OF A FOREST TRANSPORT SYSTEM TAKING INTO ACCOUNT THE STOCHASTIC COMPONENT

Research group:

Enaleeva- Bandura I., Kovalev R., Brovkin S., Chesakova S., Burkina A., Shuvalova V., Shtern S.

MULTIPLE INPUTS AND MIXED DATA FOR MACHINE LEARNING MODELS

Hurieieva $\mathrm{K}$.

USING OF «UTAS SYSTEM» DATA AT RISK-ORIENTED APPROACH TO THE OCCUPATIONAL SAFETY SYSTEM ORGANIZATION ON MINES OF UKRAINE

Griadushcha V.

ВИКОРИСТАННЯ DOUBLE VPN - АНОНІМНІСТЬ ТА БЕЗПЕКА В IHTEPHETI

Шкребтій А.B.

ВИКОРИСТАННЯ МАСЛЯНКИ ДЛЯ ВИРОБНИЦТВА ОЗДОРОВЧОГО НАПОЮ 3 КОМБІНОВАНИМ СКЛАДОМ 
6 • Scientific discoveries: projects, strategies and development $\bullet$ Volume 1

СИРОВИНИ

Стеценко Н.O.

ІДЕНТИФІКАЦІЯ КОРИСТУВАЧІВ МОБІЛЬНИХ ПРИСТРОЇВ НА ОСНОВІ ДИНАМІКИ НАБОРУ ПАРОЛЬНОЇ ФРАЗИ

Мазниченко Н.I.

ІНФОРМАЦІЙНІ ТЕХНОЛОГІЇ СИСТЕМИ ПІДТРИМКИ ПРИЙНЯТТЯ РІШЕНЬ В ПРОЦЕСАХ УПРАВЛІННЯ ВЗАЕМОВІДНОСИНАМИ ВИДАВНИЧО-ПОЛІГРАФІЧНИХ ПІДПРИЕМСТВ ЗІ СТЕЙКХОЛДЕРАМИ

Андрющенко Т.Ю.

МІНЕРАЛЬНИЙ СКЛАД ЕКСТРАКТІВ ЧАЮ РІЗНОГО ПОХОДЖЕННЯ

Соколова О.М.

МОДЕЛЬ ОЦІНКИ НАДІЙНОСТІ ПРОГРАМНОГО ЗАБЕЗПЕЧЕННЯ ІНФОРМАЦІИНО-УПРАВЛЯЮЧИХ СИСТЕМ СПЕЦІАЛЬНОГО ПРИЗНАЧЕННЯ

Науково-дослідна група:

Ляшенко І.О., Войтко О.В., Шевченко Д.Г., Маланчук М.Ф., Мулявка А.С., Прима М.В.

НАПІВФАБРИКАТИ ДЛЯ ЗБАГАЧЕННЯ ХАРЧОВИХ ПРОДУКТІВ ДЛЯ ВІЙСЬКОВОСЛУЖБОВЦІВ

Гойко І.Ю.

ОБҐРУНТУВАННЯ ШЛЯХІВ ЕКОНОМІЇ ПАЛИВНО-МАСТИЛЬНИХ МАТЕРІАЛІВ БЮДЖЕТНОЇ УСТАНОВИ

Коренчук К.В.

ОБҐРУНТУВАННЯ ШЛЯХІВ РАЦІОНАЛІЗАЦІЇ МАТЕРІАЛЬНОТЕХНІЧНИХ ВИТРАТ НА ЗАБЕЗПЕЧЕННЯ ЕКСПЛУАТАЦІЇ ТРАНСПОРТНИХ ЗАСОБІВ

Чмир В.М.

ОРГАНІЗАЦІЯ НАВЧАННЯ УЧНІВ 3 ВИКОРИСТАННЯМ ВІРТУАЛЬНОГО КАБІНЕТУ ФІЗИКИ

Банак Р.Д. 108

ПОЛІТИКА БЕЗПЕКИ ВЕБ-РЕСУРСІВ

Розломій I.O.

РЕКУРЕНТНІ НЕЙРОННІ МЕРЕЖІ ТА ДОВГА КОРОТКОЧАСНА ПАМ'ЯТЬ

Тимофєєва А.є. 


\section{SECTION IV. PHYSICS AND MATHEMATICS}

ТЕХНОЛОГІЯ ПРОБЛЕМНОГО НАВЧАННЯ ТА ІІЇ ЗАСТОСУВАННЯ НА УРОКАХ МАТЕМАТИКИ

Рудікевич С.Ю.

\section{SECTION V.} BIOLOGY

FATTY ACID COMPOSITION OF CITRUS OILS Osyp Yu., Osyp M.A

ЕКОЛОГІЧНИЙ АНАЛІЗ ТА ОЦІНКА СТІЙКОСТІ ДЕНДРОФЛОРИ ТОМИЛІВСЬКОГО ПАРКУ

Левандовська С.М. 
8 - Scientific discoveries: projects, strategies and development $\bullet$ Volume 1

\title{
SECTION I. \\ ECONOMICS
}

DOI 10.36074/25.10.2019.v1.01

\section{CLASSIFICATION CRITERIA OF STRUCTURE CATEGORIES OF SERVICE SECTOR}

\author{
Valentyna Stolyarchuk \\ Ph.D. (Engineering), Associate Professor of the Hotel, \\ Restaurant and Resort Business Department \\ Higher Educational Institution of Ukoopspilka \\ 'Poltava University of Economics and Trade'
}

UKRAINE

Since XX century services constitute the engine of economic growth and account for $70 \%$ of GDP and employment in most countries [1; 2]. So, the service sector is dominant in the structure of national production in most countries of the world [2].

As shown by the analysis of information sources, today there is no consentient opinion in a representation of the sectoral structure of the service sector in both academic literatures, regulatory and legal documents. There are different requirements in the classification of data by kind of economic activity (ISIC, 2008), by kind of products and services (CPC, 2015) [3; 4]. There are differences by international and national approaches to definition classification categories of the structure and from country to country too. National analysis often requires greater detail than is required or possible for international purposes [3; 4]. In addition, there are processes of change in the structure of the service sphere, which further complicates the problem. Scientific and technological progress, the changes in the structure of the economy and organization of activities lead to the disappearance of existing types and emergence of new types of economic activities, products and services $[4 ; 5]$. As result, relevance of industry structure of some classifications over time decreases. In particular scientists note a number of problems related to an imperfection in methodological framework of border delineating of tourism, hospitality, accommodation and restaurant industry [6].

A clear unanimous delineation of service branch industries provides the ability to effective manage the activities of businesses operating in their environment. Therefore, it is important to study the sectoral structure of the service industry carefully, in particularly, the methodological approach to its determination.

Classification criteria of structure categories of service sector are different distinctively by nature and purpose of goods and services, ownership, institutional unit et al $[3 ; 4 ; 7]$. The result of the analysis of information sources show, that there are two approaches to the major consideration in industry structure classification defining (fig. 1).

The first approach to classification criteria gives more importance to the production process. In general, separate units are grouped together when they 
provide activities for a common process for producing, use similar technologies or resources.

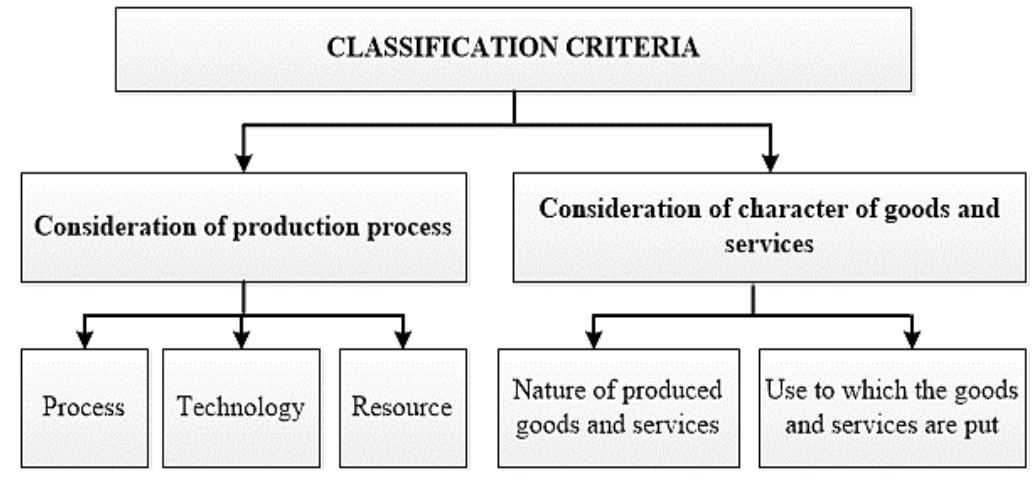

Fig. 1. Classification criteria of structure categories of service sector (Source: elaboration according to ISIC, NACE, CPC [3; 4; 7]).

The second approach to classification criteria takes into account character of provided products and services. This basis for grouping is provided for similarities in following characteristics: the nature of produced goods and services, the use to which the goods and services are put. It is important to point out that these criteria are applied differently at different levels of same classification.

Therefore, it is necessary to take into account the using purposes of certain industry structure. Clear definition of classification criteria promotes elaboration of the industry structure of service sector, which satisfies the contemporary requirements. Its practical application provides the ability to develop industries and effective manage the enterprises activities.

\section{References:}

1. The European Parliament and the Council of the European Union (2006). Directive 2006/123/EC of the European Parliament and of the Council of 12 December 2006 on services in the internal market. Official Journal of the European Union, (376), 36-67. Retrieved from http://eurlex.europa.eu/legal-content/EN/TXT/PDF/?uri=CELEX:32006L0123\&rid=3.

2. Бокоч, В. М. (2009). Інвестування сфери послуг: теоретико-прагматичні підходи. Збірник наукових праць Черкаського державного технологічного університету. Сер.: Економічні науки, $24 \quad$ (1), 178-185. $\quad$ Retrieved from http://nbuv.gov.ua/UJRN/Znpchdtu_2009_24\%281\%29_37.

3. International Standard Industrial Classification of All Economic Activities. ISIC (2008). Statistical papers Series M, No. 4/Rev.4 (ST/ESA/STAT/SER.M/4/Rev.4). Department of Economic and Social Affairs Statistics Division. Retrieved from https://unstats.un.org/unsd/cr/registry/isic-4.asp.

4. Central Product Classification. CPC (2015). Statistical Papers Ser. M No. 77, Ver. 2.1. Department of Economic and Social Affairs. Statistics Division. Retrieved from https://unstats.un.org/unsd/cr/downloads/CPCv2.1_complete(PDF)_English.pdf.

5. Методологічні основи та пояснення до позицій. Класифікації видів економічної діяльності. КВЕД (vb457609-10). (2010). Retrieved from https://docs.dtkt.ua/download/pdf/1157.1892.1. 
6. Баранова, А. Ю. (2011). Проблемы инфраструктурного обеспечения индустрии гостеприимства в муниципальных образованиях туристско-рекреационной специализации. Bonросы государственного и муниципального управления, (3), 168-179. Retrieved from http://ecsocman.hse.ru/data/2012/03/26/1269127911/Баранова\%20168-179.pdf.

7. Statistical classification of economic activities in the European Community. NACE. Rev. 2. (2008). General and regional statistics Collection: Methodologies and working papers. European Commission. Retrieved from http://ec.europa.eu/eurostat/documents/3859598/5902521/KS-RA07-015-EN.PDF.

\section{ENTWICKLUNG VON AUSLÄNDISCHEN DIREKTINVESTITIONEN IN DER UKRAINE}

\section{Sofiia Kotsur Nationale Wirtschaftsuniversität Ternopil}

UKRAINE

Unter den heutigen Bedingungen hängt die wirtschaftliche Entwicklung der Ukraine in hohem Maße von effektiven Investitionen ab, die eine Schlüsselrolle für die nationale Wirtschaftsentwicklung spielen. Dies trifft sowohl auf nationale als auch auf ausländische Direktinvestitionen zu. Nach der Definition des Internationalen Währungsfonds aus dem Jahr 1993 trifft eine ausländische Direktinvestition zu, wenn langfristiges Interesse zur Beteiligung des ausländischen Unternehmens am Eigenkapital der einheimischen Unternehmung von mindestens zehn Prozent führt und damit ein erheblicher Einflusses auf die Unternehmenssteuerung erreicht wird [2]. Die Direktinvestition führt im Unterschied zur Portfolioinvestition zu Einfluss und Kontrolle auf die Geschäftstätigkeit des finanzierten Unternehmens mit dem Ziel des erwarteten Gewinns.

Zu den zehn wichtigsten Hauptinvestorenländern, auf die 83\% der gesamten Direktinvestitionsquote entfallen, gehören Zypern - 15,7 Mrd. USD, Deutschland -5,9 Mrd. USD, die Niederlande - 5,3 Mrd. USD, die Russische Föderation $3 \mathrm{Mrd}$. USD, Österreich - 2,8 Mrd. Dollar, Großbritannien - 2,4 Mrd. Dollar, Jungferninseln - 2 Mrd. Dollar, Frankreich - 1,7 Mrd. Dollar, die Schweiz - 1,4 Mrd. und Italien - 1 Mrd. Dollar [1]. Gegenwärtig lässt sich bemerken, dass durch Auslandsinvestitionen wirtschaftliche Beziehungen bedeutet verbessert werden können, wobei nationale und internationale finanzielle und wirtschaftliche Aktivitäten kombinieren sind. Trotz politischer Instabilität, unsicherer finanzieller Lage, Unruhen im Osten der Ukraine und die russische zeitweise Okkupation der Krim, bietet das Land sich als potenzieller Geschäftspartner für ausländische Unternehmen an. Hervorzuheben sind einige hochentwickelte Nischensektoren: z.B. die Eisen- und Nichteisenmetallurgie, der Transithandel zwischen Ost und West sowie Nord und Süd, die Öl- und Gasindustrie, Maschinenbau und Metallbearbeitung, Zement- und Wollindustrie, Kohlegewinnung und Verarbeitung, chemische Industrie, alternative Elektrizitätsgewinnung, die Medizin und der ITBereich [2]. 
Der Zufluss von ausländischen Direktinvestitionen benötigt als Basis ein Vertrauensverhältnis zwischen Investoren und dem rechtlichen und wirtschaftlichen Umfeld. Grundlage für die Tätigkeit ausländischer Unternehmen in der Ukraine ist das Gesetz über Auslandsinvestitionen, in dem wesentliche Garantien für den Schutz von Auslandsinvestitionen festgelegt wurden [3].

Für die Zukunft ist es bereits heutzutage notwendig, damit zu beginnen, das aufgrund politischer Faktoren bestehende eher negative Investitionsabbild zu verbessern. Der Investitionsstandort Ukraine mit seinen regional unterschiedlichen natürlichen, aber wirtschaftlich und rechtlich einheitlichen Umfeldern muss mehr positive Signale an die Weltwirtschaft senden [4]. Ausländische Direktinvestoren brauchen in der Ukraine ein Willkommensklima, das innen erlauben würde, ihre Geschäftsideen im Rahmen der ukrainischen Gesetze durch Einflussnahme auf Geschäftsprozesse in den Unternehmen und auf die Beschaffungs- und Absatzmärkte der Ukraine durchzusetzen. Dabei wäre wünschenswert, den ausländischen Investoren seitens staatlicher Einrichtungen mehr Unterstützung zu geben. Ein erfolgreicher Auslandinvestor bringt unbedingt solcher Weise dem ukrainischen Umfeld bestimmte Vorteile mit.

\title{
Referenz:
}

1. Anlagepolitik. Abgerufen von http://dniprorada.gov.ua/investicijn-politika.

2. Offizielle Website des Ministeriums für wirtschaftliche Entwicklung und Handel der Ukraine. Abgerufen von http://www.me.gov.ua.

3. Die offizielle Website der Firma "Dragon Capital". Abgerufen von http://www.dragon-capital.com.

4. Offizielle Website des Zentrums für soziale Kommunikationsforschung. Abgerufen von http://www.nbuviap.gov.ua.

\section{FEATURES OF FORMATION OF FINANCIAL POTENTIAL OF THE ENTERPRISE}

\begin{abstract}
Andrii Pecheniuk
Ph.D. (Economics), Associate professor State Agrarian and Engineering University in Podilya

Viktoriia Dakhno applicant for higher education at the Faculty of Economics State Agrarian and Engineering University in Podilya

UKRAINE

In the conditions of increasing competition both in the national and international markets, the enterprises face the problem of efficient use of available resources, search for reserves for improving production productivity, optimization of property structure [1].

Domestic enterprises are facing the problem of directing their activities not only to meet current needs, first of all in the form of profit, but also to plan future activities and increase their financial capacity [3].
\end{abstract}


It is financial potential that is one of the main factors that determine the success of an enterprise in the current environment. Usually, it is often identified with the available funds of the financial resources of the firm, the ability to rationally and effectively use the funds at its disposal, as well as the ability to increase, if necessary, the volume of these resources [4].

Under the financial potential of an enterprise should be understood the totality of financial opportunities for its development, due to the availability of sufficient amount of financial resources, personnel and information support, an effective system of financial management, aimed at achieving the strategic financial position of the enterprise in the external environment [5].

The future development of the enterprise and the possibility of investing funds are influenced by external and internal factors. The first are related to the state of the economy as a whole, the legal regulation of the enterprise, political processes in society, as well as financial resources of the state, etc. The second should be considered as internal capabilities and available resources that the enterprise can count on to achieve its goals [3].

The process of forming the proper financial potential of an enterprise is a complex phenomenon that depends on many factors [4].

The assessment of the financial potential of the enterprise should be based on the analysis of indicators of its business activity, profitability, liquidity, solvency, financial stability, property status, etc.

The practice of many leading companies shows that they use such methods as PEST analysis, SWOT analysis, SNW analysis, scenario analysis to analyze the financial environment factors; portfolio analysis, etc. [2].

When assessing the financial potential of an enterprise, the efficiency of the use of existing financial resources and strategic directions of business development are taken into account. However, due to the significant dependence of the financial capacity of the enterprise on changes in the economic environment, it is necessary to take into account the influence of a number of relevant factors [4].

Successful implementation of planned tasks and their operational correction are impossible without the organization of an effective system of monitoring, accounting and control of the implementation of the plan of development and use of the financial potential of the enterprise [6].

The main components of the strategy of financial potential management are:

- diagnostics and forecasting of the financial potential of the enterprise;

- strategic and tactical planning;

- the choice of effective financial instruments;

- financial risk management;

- tax planning;

- legal formalization and further control of financial flows [2].

The process of objective planning of financial capacity is one of the most effective tools for minimizing financial risks. After all, planning enables the rapid use of favorable market opportunities, identify potential problems in advance, ensure coordination and interaction of structural units of the enterprise, optimize the allocation of financial resources between competing areas of their use [6].

Achieving a synergistic effect in realizing the financial potential of an enterprise is possible only if the combination of strategic financial resources with other elements of financial potential (personnel, organizational and information components). This will help increase the financial potential of the enterprise and ensure sustainable competitive advantages [5]. 
The process of managing the financial potential of an enterprise is aimed at optimizing financial resources in order to achieve the highest possible positive result [1].

Effective realization of financial potential is a signal for potential investors, creditors, shareholders, state structures and other external entities of valuation regarding the expediency of investing funds in the enterprise [4].

Achieving an adequate level of financial potential is important for the activity of each enterprise, because it characterizes the state of use and development of internal capabilities of the enterprise, on the other hand - the response of the enterprise to external threats that arise in the market in the process of interaction with other business entities and by the state.

\title{
References:
}

1. Ареф'єва, О. В., Андрієнко, М. М. \& Кравченко, О. Р. (2018). Управління фінансовим потенціалом підприємства. Економіка і суспільство, (18), 252-257.

2. Бондар, О. А. \& Куліков, П. М. (2017). Оцінка фінансового потенціалу підприємства. Економічний вісник, (4), 161-165.

3. Куліш, Г. П. \& Чепка, В. В. (2017). Фінансовий потенціал підприємства та його роль в умовах нестабільності економіки. Статистика України, (1), 29-35.

4. Партин, Г. О., Задерецька, Р. І. \& Граціян, О. В. (2019). Формування фінансового потенціалу підприємства. Вилучено з http://www.economy.nayka.com.ua/?op=1\&z=4754.

5. Саух, І. М. (2017). Фінансовий потенціал підприємства як об'єкт стратегічного аналізу. Економічний часопис Східноєвропейського національного університету імені Лесі Українки, (1), 132-141.

6. Стецюк, П. А. \& Корнійчук, Г. В. (2017). Теоретичні та практичні аспекти організації планування фінансового потенціалу підприємств. Економіка. Менеджмент. Бізнес, (4/22), 12-18.

\section{INTEGRAL INDICATOR OF INNOVATION SECURITY AS A TOOL FOR ASSESSING THE INNOVATIVE DEVELOPMENT OF COUNTRIES}

\author{
Valeriia Gnidina \\ master's degree in Economics \\ Mariupol State University \\ UKRAINE
}

Innovative security is one of the key components of economic security of the country. Security of innovative development provides balanced proactive innovative development in all areas of activity, which guarantees the most effective use of existing and safe attraction of additional investment resources. Therefore, it becomes relevant to identify and neutralize threats to innovation security by evaluating it, which can be carried out using a variety of techniques methods.

Firstly, it should be noted that the issue of defining the concept of «innovation security» is very important for its further evaluation. On the one hand, it is defined 
as the state of scientific, technological and production potential of the state, which makes it possible to ensure the stable functioning of the economy in the event of certain threats at the expense of its own resources. According to the second approach, innovation security is a set of conditions and innovative factors that ensure the independence of the national economy, its innovative development, the ability to achieve sustainability and international competitiveness. Taking into account all the approaches considered by us to the assessment the innovation component, it is proposed the own sequence of assessment of the innovation security.

At the first stage of the model, a system of indicators for assessing innovative development should be defined. The formation of a set (list) of indicators is carried out according to the principles of representativeness (the most significant indicators affecting the level of innovation security are included), reliability (adequately reflect the state of the security component) and information availability (official statistical data and public expert assessments are used during the calculation).

Thus, the four blocks were identified, which are separate sub-indices in the areas of innovation (fig.1).

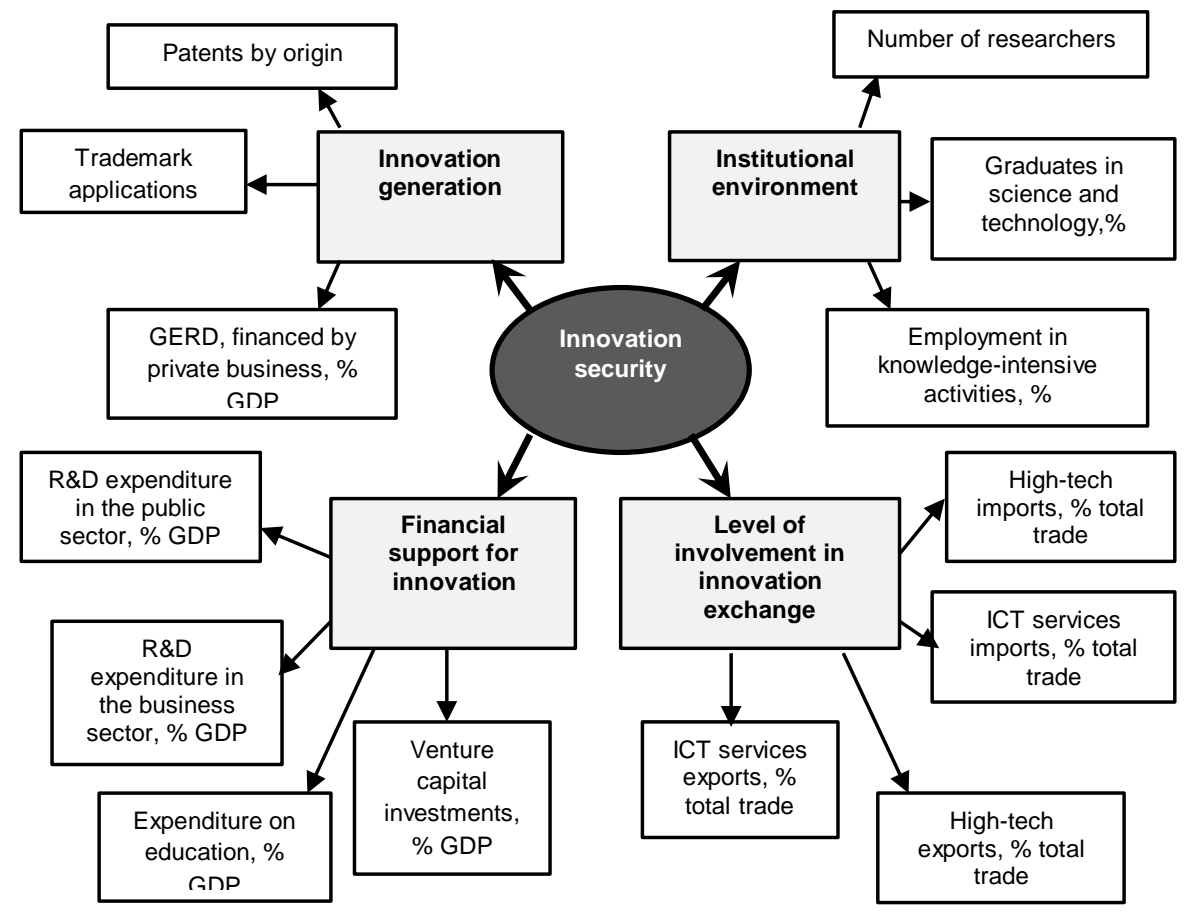

Fig. 1. Blocks of indicators for the assessment of innovative security

After determining the indicators, the next stage of assessing the level of innovation security is the establishment of normative values of indicators, which 
allows to identify potential danger zones and the level of danger. But first, it should be noted that the normalization of indicators-stimulators and destimulators is different. Stimulators are indicators, the increase in the value of which characterizes the improvement of innovation security, and the value of destimulators, on the contrary, deterioration. In our case, all indicators are stimulators, except for hightech imports (\% total trade) and ICT services imports (\% total trade), because a large share of imported innovations doesn't ensure the independence of the country's innovation system from other systems. That is, the lower the values of these two indicators of the block, the higher the level of innovative security and safety in general.

Transformation of innovative indicators can be carried out in various ways, the choice of which largely depends on the value of the integral indicator. It is possible to allocate four basic ways of transformation of the indicators (table 1) [1, p.83-86].

\section{Transformation's methods of basic indicators}

Table 1

\begin{tabular}{|c|c|c|}
\hline $\begin{array}{c}\text { Method of } \\
\text { normalization }\end{array}$ & Essence & Formula \\
\hline $\begin{array}{l}\text { Normalization } \\
\text { by coefficient } \mathrm{k}\end{array}$ & $\begin{array}{l}\text { The calculation of the ratio values } \\
\text { compared to the average/ maximum (i.e., } \\
\text { selected benchmark) or the ratio of } \\
\text { average values for the group of objects to } \\
\text { the index value of the object. }\end{array}$ & $\mathbf{S : ~} z_{i}=\frac{x_{i}}{k_{\text {norm }}}, \mathbf{D}: z_{i}=\frac{k_{\text {norm }}}{x_{i}}$ \\
\hline $\begin{array}{l}\text { Min-Max } \\
\text { method }\end{array}$ & $\begin{array}{l}\text { Equalization of minimum and maximum } \\
\text { values for all indicators in order to } \\
\text { eliminate differences in the spread of } \\
\text { indicator values. }\end{array}$ & $\begin{array}{l}\text { S: } z_{i}=\frac{x_{i}-x_{\min }}{x_{\max }-x_{\min }} \\
\mathbf{D :} z_{i}=\frac{x_{\max }-x_{i}}{x_{\max }-x_{\min }}\end{array}$ \\
\hline Standardization & Normalization by the standard deviation & S: $z_{i}=\frac{x_{i}-x_{i}}{\sigma_{i}}, \mathbf{D}: z_{i}=\frac{x_{i}-x_{i}}{\sigma_{i}}$ \\
\hline $\begin{array}{l}\text { Standardization } \\
\text { by taking the } \\
\text { logarithm }\end{array}$ & $\begin{array}{l}\text { Reducing the variation between values is } \\
\text { possible by taking the logarithm current, } \\
\text { minimum and maximum values }\end{array}$ & $\begin{array}{l}\mathbf{S :} z_{i}=\frac{\log x_{i}-\log x_{\min }}{\log x_{\max }-\log x_{\min }} \\
\mathbf{D :} z_{i}=\frac{\log x_{\max }-\log x_{i}}{\log x_{\max }-\log x_{\min }}\end{array}$ \\
\hline Explanation & \multicolumn{2}{|c|}{$\begin{array}{l}\mathrm{S} \text { - stimulators; } \mathrm{D} \text { - destimulators; } z_{\mathrm{i}} \text { - normalized value of the indicator; } \mathrm{k} \text { - } \\
\text { normed coefficient; } x_{\mathrm{i}} \text { - the actual value of the indicator; } x_{\min }, \mathrm{x}_{\max } \text { - the } \\
\text { minimum, maximum value; } x_{i} \text { - the average value; } \sigma_{i} \text { - standard deviation. }\end{array}$} \\
\hline
\end{tabular}

It is significant that the most popular are 2 and 3 methods of normalization. In these the spread of their values is preserved, the nature of the differences between the objects according to individual indicators is displayed absolutely adequately. Thus, the obtained normalized values of security indicators (from 0 to 1 ) by any of the methods characterize the degree of approximation to the optimal value of 1 or $100 \%$.

The next step is to determine the weight coefficients - assigning weight to the values of indicators/subindicators. The vast majority of researchers use expert assessments. But there are also the following approaches to determining weight coefficients: modeling, principal component method, game (matrix) methods and etc. 
After weighing the indicators, it is important stage the calculation of the integral index of innovation security. Thus, the security index is determined hierarchically: at the lower level - the indices for individual blocks of innovations (generation of innovations, institutional environment, financial support and level of involvement in the exchange of innovations); at the top - the index of innovation security. There are also two main approaches to the calculation of indices, which also differ in its mathematical representation: the linear model (the sum of weighted averages); multiplicative model (multiplication of weighted average geometric parameters). Thus, the calculation of the integral indicator for each block of innovations can be carried out according to the formulas (1) [2, p. 10-11]:

$$
\begin{gathered}
I_{1-4}=\sum_{i=1}^{n} w_{i} x_{i} \\
I_{1-4}=\prod_{i=1}^{n} x_{i} w_{i}
\end{gathered}
$$

where:

$I_{1-4}-$ sub-index for the four blocks; $x_{i}-$ value of the indicator by the total number $\mathrm{N}$;

$w_{i}-$ weighting coefficients of indicators;

$\Pi$ - multiplication of the arguments with numbers $i=1,2,3, \ldots, N$.

On the basis of four calculated sub-indices by blocks, the integral indicator of innovation security of countries with the same formulas is calculated (2):

where:

$$
\begin{gathered}
I_{\text {in }}=\sum_{i=1}^{4} w_{i} I \\
I_{\text {in }}=\prod_{i=1}^{4} I^{w_{i}}
\end{gathered}
$$

$l_{\text {in }}$ - integral indicator of innovation security; I- sub-index for the four blocks;

$w_{i}-$ weighting coefficients of the four blocks;

Thus, these two methods represent alternative approaches to the calculation of the indicator. After calculating the integral index, countries are ranked according to its value ( 0 to 1$)$. The critical value of the innovation safety index is considered to be 0,2 or $20 \%$; unsafe - 0,4 or $40 \%$; saticfactory - 0,8 or $80 \%$; optimal - 1 or $100 \%$.

In conclusion, it should be noted there is the universality of the proposed method of assessment the economics' innovation security. The integral index will serve as a effective tool for the practical study of innovation processes in the world.

\section{References:}

1. Handbook on Constructing Composite Indicators: methodology and user guide. (2008). OECD, 162 p. Retrieved from https://www.oecd.org/sdd/42495745.pdf.

2. Клюшникова, Е. В. \& Шитова, Е. М. (2016). Методические подходы к расчету интегрального показателя, методы ранжирования. Электронный научно-практический журнал «ИнноЦентр», (10), 6-11. Извлечено с http://innoj.tversu.ru/Vipusk1(10)2016/2\%20\%20\%D0\%9A\%D0\%BB\%D1\%8E\%D1\%88\%D0\%BD\%D0\%B8\%D0\%BA\%D0\%BE\%D0\%B2\%D $0 \%$ B0.pdf. 


\title{
PROFESSIONAL EDUCATION IN UKRAINE IN CONDITIONS OF THE GLOBAL ECONOMY
}

\author{
Iryna Denchyk \\ Kharkiv Educational and Scientific Institute "University of Banking» \\ Scientific adviser: Veronika Kovalchuk \\ D.Sc. (Public Administration), Associate professor \\ Kharkiv Educational and Scientific Institute "University of Banking»
}

UKRAINE

The relevance of the study of vocational education and training is due to the negative trends observed in our society: lack of purposeful state strategy and policies in the field of vocational training, in particular taking into account both the specificity of industry and the peculiarities of economic activities of large, medium and small enterprises to ensure the high competitiveness of the national workforce; the lack of interest and financial inability of employers to provide training, retraining and advanced training of their staff; low level of stimulation of professional development of employees; lack of a unified system of professional qualifications and standards for vocational training; lack of training infrastructure for enterprises. This is the reason for the need for a detailed study of the organization of vocational training both in educational institutions and enterprises, on the basis of which it is possible to develop a science-based policy to regulate the development of vocational training in Ukraine.

In the global economy, modern vocational education plays a key role in improving the prospects of socio-economic development. It contributes to the dynamism of the economy, the development of knowledge and modern skills, reducing the level of inequality. With its rich history of higher education and scientific and technological development Ukraine has good opportunities to modernize the education system and to take advantage of the benefits of globalization. Vocational education should be the generator of new ideas and technologies and ensure the formation of highly educated human resources.

Achieving national and global competitiveness of vocational education is impossible without a preliminary analysis of its current state, aimed at diagnosing existing problems and identifying reserves that contribute to their effective solution. Such a study requires a clear definition and the necessary degree of detailing the competitiveness in the field of vocational education. Therefore, it is necessary to analyze the content and identify a set of factors that affect its condition. The current global changes in the world show that education is defined and allocated by many countries as a priority area of socio-economic development, a means of maintaining competitiveness and a leading position in the world markets.

The driving force of the modern world economy is knowledge in the form of ideas and modern technologies. The pace of change and renewal has increased dramatically, goods and resources are being easily moved across national borders, and new communications and information processing facilities are rapidly spreading. 
Schools' susceptibility to change is important success factors. First and foremost, they must meet the needs of a "knowledge economy" in the face of global competition. Specific areas for improving vocational education may be the introduction of new programs, broadening the range of research and consulting activities for domestic and international companies and developing cooperation with foreign universities with high reputation and significant resources.

In seeking to improve the quality of training programs strengthening the linkages of educational institutions with new industries and expanding the scope of vocational education the government has strong advantages in terms of future growth and competitiveness in a knowledge-based global economy.

In order to develop and improve the quality of vocational education in Ukraine, first of all, it is necessary to ensure:

- creation of socio-economic conditions for the priority development of vocational education;

- regulatory financing of educational institutions;

- promotion of non-state investments in educational systems, including by providing tax and customs privileges for legal entities and individuals involved in the development of educational institutions;

- involvement of employers and other clients of personnel in social partnership and organization of vocational education in order to meet the needs of the labor market;

- legal conditions for the functioning and development of educational institutions of different forms of ownership;

- legislative consolidation of material, administrative and property responsibility of the founders of educational institutions and increasing the responsibility of employers;

- high employment of able-bodied population;

- ensuring stable financing of educational institutions, compliance with labor legislation, first and foremost in terms of full and timely remuneration;

- implementation of social guarantees and benefits for education workers and students;

- support for different forms of self-organization of students as an integral part of the entire education system;

- integration of the Ukrainian education system into the world education system, taking into account national experience and traditions;

- active entry into the market of educational services, wide participation of institutions of vocational education and teachers in international educational programs of international organizations and communities.

All these measures for the transformation of vocational education require the need for scientific and methodological support, the review of established (traditional) approaches, the search for new principles of designing the content of education and new educational technologies. Ways to modernize vocational education provide for the solution of three key interrelated challenges: the quality of vocational education, its accessibility and effectiveness.

One of the strategic tasks of the modern state policy of Ukraine in the field of vocational education is to gradually overcome the gap in the structure, volumes and 
quality of training of skilled workers and specialists from the requirements of the modern labor market.

The problems have been identified, as practice shows, can be solved only within the framework of new state-public relations in conditions where the public component becomes a dominant and effective factor at all levels of government.

The modernization of education is a political and national task and its purpose is to create a mechanism for sustainable development of the education system, which ensures the formation of a holistic picture of the world, high quality education that meets the challenges of the 21st century, the social and economic needs of the country's development, the educational needs of the person, society, state, and takes into account labor market development forecasts.

\section{References:}

1. Афранасьєв, М. (2010). Неперервна профресійна освіта: Нові горизонти підготовки кадрів для постіндустріальної економіки. Вища школа, (10), 88-98.

2. Хаджирадєва, С. К., Воронова, С. В. \& Кравцова, Н. Є. (2017). Сучасний контент профресійного розвитку менеджерів освіти в умовах глобальних викликів та реформ (Ч. 2).

DOI 10.36074/25.10.2019.v1.02

\section{«БЛАКИТНИЙ ОКЕАН»: НЕОБХІДНІСТЬ ЧИ ПРИВІЛЁ̈?}

Гуняга Наталія Олексіївна

магістр фракультету обліку, аудиту та інформаційних систем Київський національний торговельно-економічний університет

Науковий керівник: Барабаш Наталія Степанівна канд. екон. наук, доцент, доцент кафедри фрінансового аналізу та аудиту Київський національний торговельно-економічний університет УКРАЇHA

У складних умовах розвитку та «виживання» підприємницької діяльності неухильно підвищується роль сучасних підходів до стратегічного управління, при цьому однієї з найважливіших стратегій є конкурентна стратегія. Натомість не всі підприємства готові заплутуватися у вічній конкурентній боротьбі, в якій кожен учасник ринку може досягти незначних успіхів, деякі обирають стратегію «блакитного океану» щоб отримати більший прибуток в абсолютно новому ринку.

За останнє десятиліття розвитку економіки питання конкуренції, методів боротьби та захисту підприємств від конкурентів розкрито вченими економістами на достатньо глибоко, на відміну від питання виходу 3 конкурентної боротьби та створення власної (нової) ніші.

Вперше дослідженням питання створення, розвитку та існуванням блакитного (позаконкурентного) ринку зайнялися економісти Чан Кім та Рене 
Моборн, які перенесли свій інтерес з площини конкуренції в площину існування підприємства на межі інноваційності та цінності.

Стратегія «блакитного океану» являє собою одночасне прагнення до диференціації та низької вартості товару/послуг, відкриття нового ринкового простору за рахунок створення нового незадоволеного попиту, що робить конкуренцію нерелевантною. Завдяки даній стратегії підприємці приходять до висновку, що ринкові межі та галузеві структури не $є$ заданими і можуть бути реконструйовані діями та переконаннями галузевих гравців [1].

Стратегія «блакитного океану» виступає лише «навігатором» для підприємств під час виходу з червоного океану (конкурентного ринку). При цьому не враховується сектор економіки, галузь та розмір підприємства, а головною рисою $є$ створення нових галузей, унікальних продуктів або послуг, що мають задовольняти попит споживачів та руйнувати межі існуючого ринкового простору, стверджуючи, що одночасне прагнення до диференціації та низької вартості $€$ досяжним.

Диференціація продукту відбувається за рахунок інноваційності, ефективності, правильної цільової аудиторії та якості, що закладена у досконалість та надійність продукту [2].

За даними статистики OECD 96\% власників підприємств визначають інновації стратегічним пріоритетом. Однак саме відсутність чіткої інноваційної стратегії з правильно визначеною вартістю продукту $€$ основоположними проблемами оптимізації та ефективності діяльності. Прагнення до переходу стратегії «блакитного океану» обґрунтоване тим, що «червоний океан» з часом стає переповненим і перспектива отримання прибутку зменшується, або взагалі зникає. Тому «блакитний океан» створюється в умовах, де дії підприємства сприятливо впливають як на структуру витрат, так і на інноваційну цінність для отримання прибутку. Економія витрат здійснюється завдяки усуненню та зменшенню факторів, за якими конкурує галузь. Інноваційна цінність підвищується шляхом підняття та створення елементів, які галузь ніколи не пропонувала. 3 часом витрати зменшуються ще більше, при одночасному збільшенні обсягів реалізації [3].

Оскільки найчастіше правилами «червоного океану» керуються маркетологи через те, що споживачі пов'язують бренди з певними їх продуктами - підгузки - «Pampers», браузер - Chrome - доводячи, що торгові марки є «акулами» в розрізі продукції свого «червоного океану», то при створенні конкурентної стратегії часто існують такі терміни, як: побиття ринку з точки зору ціни, місця або географії просування товару/послуг, при цьому відбувається зосередження на просуванні та зменшенні витрат через зміну пропозиції, в той час, як стратегія «блакитного океану» будується в ціновій категорії через «ціновий коридор». А побудова інноваційної цінності починається 3 аналізу поточного стану підприємства та визначення реальної необхідності у пошуку найкращого конкурентного рішення.

Головним елементом стратегії «блакитного океану» можна вважати споживачів та визначення умов взаємодії з ними. Розуміння сегменту, клієнтів, ïx незадоволених потреб допомагає створити унікальну перевагу альтернативного варіанту. Приймаючи до уваги те, що для кожного рішення $\epsilon$ альтернативи, навіть якщо це означає нічого не робити або використовувати 
високотехнологічне виробництво. Характеристика нових функцій продукту, які можна створити чи замінити, створить нове мислення та збільшить час монопольного володіння новоствореним ринком [1].

3 урахуванням наведеної характеристики, яка виступає перевагами стратегії «блакитного океану» більшість підприємств не використовують цю стратегію через високу ризикованість, відсутність значних фрінансових ресурсів, відповідних навичок та технологій, неефективного маркетингового підходу, що призводить до зникнення товару одразу після запуску. Тому використання відповідного аналітичного забезпечення для перевірки ідеї, щодо переходу у «блакитний океан» $є$ необхідним процесом і складається 3 трьох інструментів, направлених на зменшення невизначеності, що перешкоджає оцінці інноваційності та комерційної готовності до нових бізнесідей, а саме: «карта корисності для покупців», що відображає привабливість ідеї для споживачів, «ціновий коридор маси», що визначає ціну, за якої буде досягнуто найбільшої кількісті споживачів та «гід бізнес-моделі», що ілюструє, як підприємству вигідніше створити нову бізнес-ідею.

Для створення нових товарів і завоювання нових ринків потрібна як творчість, креативність, інтуїція, так і аналітичні інструменти, які $\epsilon$ в стратегії «блакитного океану». Вони дають змогу підприємству визначити необхідність, напрямок і кроки для генерації та впровадження нових ідей. Розглянутий підхід $€$ ефективним для сучасних підприємств в умовах загострення конкурентної боротьби на ринку, оскільки тільки підприємства, які постійно займаються інноваціями та орієнтовані на споживачів, мають можливість отримувати надприбутки в майбутньому. Основним напрямком для подальших досліджень у цій галузі $€$ пошук можливих комбінацій поєднання та взаємодії діджитал маркетингу та стратегії «блакитного океану» для пошуків шляхів та механізмів впровадження даних аналітичних методів та підходів у сучасну концепцію розвитку.

\section{Список використаних джерел:}

1. W. Chan Kim \& Renee Mauborgne. (2017). Blue Ocean Shift: Beyond Competing - Proven Steps to Inspire Confidence and Seize New Growth. Hachette, UK. ISBN 978-0316314046.

2. Roth, S., Valentinov, V., Kaivo-oja, J. \& Dana, L. (2018), Multifunctional organisation models. Journal of Organizational Change Management, Vol. 31, (7), 1383-1400. https://doi.org/10.1108/JOCM-05-2018-0113.

3. Holt, Douglas \& Cameron, Douglas. (2010). Cultural Strategy. Oxford University Press. ISBN 9780-19-958740-7. 


\title{
ГРУПУВАННЯ ВИДІВ ТА ВИЗНАЧЕННЯ КРИТЕРІЇВ ЕКОНОМІЧНОГО ЗРОСТАННЯ ПІДПРИЄМСТВ
}

\author{
НАУКОВО-ДОСЛІДНА ГРУПА: \\ Ємельянов Олександр Юрійович \\ канд. екон. наук, доцент \\ Національний університет «Львівська політехніка» \\ Петрушка Катерина Ігорівна \\ канд. техн. наук, асистент \\ Національний університет «Львівська політехніка» \\ Товкан Олег Емануїлович \\ канд. екон. наук, доцент \\ Національний університет "Львівська політехніка» \\ УКРАÏHA
}

Покращення фінансового стану та зростання фінансових результатів діяльності підприємств потребують розроблення та реалізації стратегій економічного розвитку суб'єктів господарювання. Результатом впровадження цих стратегій повинно стати забезпечення стійкого економічного зростання підприємств. Проте, таке зростання може мати низку різновидів, що відповідатимуть різним стратегіям його забезпечення. Враховуючи це, важливе значення має групування видів економічного зростання підприємств та встановлення критеріїв відповідних його типів.

Слід відзначити, що дослідження закономірностей економічного розвитку та зростання підприємств виконано у низці наукових праць, зокрема у [1-5], проте, питання виділення типів економічного зростання підприємств на теперішній час не є повністю вирішеним і потребує подальшого дослідження.

При оцінюванні динаміки економічних результатів діяльності підприємства, зокрема обсягів виробленої ним продукції за певний проміжок часу, доцільним $€$ зіставлення динаміки цього обсягу із динамікою інших показників діяльності підприємства. За таких умов можна виокремити декілька типових видів відносної динаміки економічних результатів діяльності підприємства, а саме:

1) залежно від співвідношення між витратами ресурсів та результатами діяльності підприємства:

- відносний ресурсозберігаючий тип економічного зростання підприємства, за якого темпи зростання обсягів виготовленої ним продукції є більшими за темпи зростання обсягів відповідних видів ресурсів;

- відносний ресурсовитратний тип економічного зростання підприємства, за якого темпи зростання обсягів виготовленої ним продукції $€$ меншими за темпи зростання обсягів відповідних видів економічних ресурсів підприємства;

- нейтральний за даною ознакою тип економічного зростання, за якого темпи зростання обсягів виготовленої підприємством продукції дорівнюють темпам зростання обсягів відповідних видів економічних ресурсів суб'єкта господарювання;

2) залежно від співвідношення між витратами економічних ресурсів підприємства та продуктивністю їх використання: 
- переважно інтенсивний тип економічного зростання підприємства, за якого темпи зростання продуктивності використання певного виду економічних ресурсів є більшими за темпи зростання обсягів цих економічних ресурсів;

- переважно екстенсивний тип економічного зростання підприємства, за якого темпи зростання продуктивності використання певного виду економічних ресурсів є меншими за темпи зростання обсягів цих ресурсів;

- нейтральний за даною ознакою тип зростання, за якого темпи зростання продуктивності використання певного виду економічних ресурсів підприємства дорівнюють темпам зростання обсягів цих ресурсів;

3) залежно від співвідношення між витратами, понесеними на експлуатацію ресурсів, та результатами господарської діяльності підприємства:

- відносний витратозберігаючий тип економічного зростання підприємства, за якого темпи зростання обсягів виготовленої ним продукції є більшими за темпи зростання витрат підприємства, пов'язаних із експлуатацією відповідних видів економічних ресурсів;

- відносний витратомісткий тип економічного зростання підприємства, за якого темпи зростання обсягів виготовленої ним продукції $€$ меншими ніж темпи зростання витрат підприємства, пов'язаних із експлуатацією відповідних видів його економічних ресурсів;

- нейтральний за даною ознакою тип зростання, за якого темпи зростання обсягів виготовленої підприємством продукції дорівнюють темпам зростання витрат підприємства, пов'язаних із експлуатацією відповідних видів його економічних ресурсів.

Окрім відносного типу ресурсозберігаючого економічного зростання підприємства, можна ввести поняття абсолютного ресурсозберігаючого зростання, за якого збільшення обсягів продукції (або значень інших абсолютних показників, що характеризують результативність діяльності підприємства) супроводжується зменшенням обсягів використання відповідного виду економічних ресурсів підприємства.

Для встановлення взаємозв'язку між зміною обсягів споживання певного ресурсу та зміною результуючого показника діяльності підприємства доцільно подати темпи приросту цих показників у такому вигляді:

$$
\begin{gathered}
\alpha=V_{1} / V_{0}-1=I_{V}-1=I_{p} \cdot I_{v}-1 ; \\
\beta=Q_{1} / Q_{0}-1=I_{Q}-1=I_{p} \cdot I_{q}-1,
\end{gathered}
$$

$\partial e:$

a - темп приросту результуючого показника діяльності підприємства, частки одиниці;

$V_{1}, V_{0}$ - величина результуючого показника діяльності підприємства відповідно у звітному та базовому періодах, грошових одиниць;

$I_{V}$ - індекс результуючого показника діяльності підприємства $\left(I_{V}=V_{1} / V_{0}\right)$;

$I_{p}$ - індекс фрізичних обсягів реалізації продукції підприємства;

$l_{v}$ - індекс результуючого показника діяльності підприємства у розрахунку на одиницю фрізичного обсягу продукції $\left(I_{v}=I_{V} / I_{p}\right)$;

$\beta$ - темп приросту обсягів споживання підприємством певного ресурсу, частки одиниці;

$Q_{1}, Q_{0}-$ обсяги споживання певного ресурсу підприємством відповідно у звітному та базовому періодах; 
$I_{Q}$-індекс обсягів споживання певного ресурсу підприємства $\left(I_{Q}=Q_{1} / Q_{0}\right)$;

$I_{q}-$ індекс обсягів споживання певного ресурсу у розрахунку на одиницю фрізичного обсягу продукції підприємства $\left(I_{q}=I_{Q} I_{p}\right)$.

Враховуючи фрормули (1) та (2), взаємозв'язок між зміною обсягів споживання певного ресурсу та зміною результуючого показника діяльності підприємства можна представити таким чином:

$$
\frac{\alpha+1}{\beta+1}=\frac{I_{p} \cdot I_{v}}{I_{p} \cdot I_{q}}=\frac{I_{v}}{I_{q}},
$$

або

$$
\alpha=\left(I_{v} / I_{e}\right) \cdot(\beta+1)-1=I_{e} \cdot(\beta+1)-1
$$

de:

$I_{e}-$ індекс ефрективності використання підприємством певного ресурсу $\left(I_{e}=I_{V} / I_{q}\right)$.

Використовуючи формули (3) та (4), можна також встановити умови абсолютного ресурсозберігаючого економічного зростання на підприємстві за певним його ресурсом. Для цього показник $\alpha$ повинен бути додатним, а показник $\beta$ - від'ємним, тобто повинні виконуватися такі нерівності:

$$
\begin{aligned}
& I_{p} \cdot I_{v}-1>0 \\
& I_{p} \cdot I_{q}-1<0
\end{aligned}
$$

або

$$
1 / I_{v}<I_{p}<1 / I_{q}
$$

Таким чином, для того, щоб на підприємстві відбувалося абсолютне ресурсозберігаюче економічне зростання за певним ресурсом необхідним $\epsilon$ виконання двох головних умов:

1) індекс результуючого показника діяльності підприємства у розрахунку на одиницю фізичного обсягу продукції повинен перевищувати індекс обсягів споживання певного ресурсу у розрахунку на одиницю фрізичного обсягу продукції. Інакше кажучи, індекс ефективності використання ресурсу повинен перевищувати одиницю;

2) індекс фрізичних обсягів реалізації продукції повинен задовольняти нерівність (7).

Відповідно, можна виділити три основні причини того, що на підприємстві не відбувається ресурсозберігаюче економічне зростання за певним ресурсом: 1) індекс ефективності використання певного ресурсу не перевищує одиницю; 2) індекс ефективності використання ресурсу перевищує одиницю, однак, індекс фрізичних обсягів реалізації продукції $€$ занадто низьким; 3) індекс ефрективності використання ресурсу перевищує одиницю, однак, індекс фрізичних обсягів реалізації продукції є занадто високим. 


\title{
Список використаних джерел:
}

1. Волощук, Л. О. (2014). Методичні засади та проблеми оцінювання інтелектуальної складової інноваційного розвитку промислового підприємства. Економічний аналіз, 18(2), 87-94.

2. Геєць, В. М. (2015). Бар'єри на шляху розвитку промисловості на інноваційній основі та можливості їх подолання. Економіка України, (1), 4- 25.

3. Гришко, В. А., Ємельянов, О. Ю. \& І. 3. Крет, І. 3. (2010). Оцінювання поточного та стратегічного рівня інвестиційного потенціалу машинобудівних підприємств. Вісник Національного університету «Львівська політехніка» «Проблеми економіки та управління», (683), 210-215.

4. Ємельянов, О. Ю. \& Петрушка, Т. О. (2013). Чинники та закономірності розвитку технікотехнологічної бази підприємств. Схід. Аналітично-інфформаційний журнал, (6), 85-91.

5. Найдюк, В. С. (2013). Сутність та передумови інноваційного розвитку підприємств. Маркетинг і менеджмент інновацій, (4), 251-263.

DOI 10.36074/25.10.2019.v1.03

\section{ЕКОНОМІЧНА СУТНІСТЬ УПРАВЛІННЯ ДОХОДАМИ ДОМОГОСПОДАРСТВ ВІД ПІДПРИЄМНИЦЬКОЇ ДІЯЛЬНОСТІ}

\author{
Перит Ірина Олегівна \\ здобувач кафедри міжнародного туризму і готельного бізнесу \\ Тернопільський національний економічний університет
}

УКРӒ̈̈A

В умовах сучасної економіки саме домогосподарства в особі приватного підприємця проявляють себе як активні учасники економічних процесів, діючи на ринках як виробники, постачальники, управлінці, споживачі, інвестори, заощадники тощо. Фактично домогосподарства, як окремі суб'єкти економіки, здійснюють діяльність як на рівні макро так і мікробізнесу. Відтак, актуальним $€$ питання обґрунтування сутності управління підприємницькою діяльністю домогосподарств в умовах сучасного ринку.

Розуміння сутності поняття «підприємницька діяльність» та «підприємницька діяльність домогосподарств» на перший погляд схожі, однак сьогодні залишаються дискусійними. Окремі науковці, що досліджували поняття «підприємницька діяльність», зокрема Ю. Станкевич та Т. Кізима, під цим терміном розуміють також підприємницьку діяльність домогосподарств [1; 2], однак більшість авторів зводять сутність бізнесу домогосподарств до локального поняття діяльності фізичних осіб підприємців у роздрібній сфері, «човникового бізнесу», ведення домашнього підсобного бізнесу та іншого незареєстрованого сімейного бізнесу, самозайнятості тощо.

Варто акцентувати увагу на визначенні поняття «підприємницька діяльність» науковцем Д. Бутенко, який під даним терміном розуміє вид діяльності суб'єкта, що представляє собою особливу економічну функцію, яка полягає у реалізації оригінальних, нетрадиційних, відмінних від існуючих 
комерційних проектів дій з метою отримання певних економічних вигод збільшення прибутку, збереження/зростання вартості капіталу, отримання соціального ефекту тощо [3]. Таке твердження відображає потребу в критично необхідних для сучасного ринку навичок підприємця генерувати і втілювати в життя нестандартні підходи до ведення бізнесу, адже важко досягти гнучкості та бути конкурентоспроможним на ринку використовуючи застарілі методи та принципи ведення бізнесу.

Підприємницька діяльність під виробництвом, купівлею-продажем матеріальних і нематеріальних благ та під формуванням економічних відносин 3 іншими суб'єктами господарювання розуміє також і управління цими процесами. А домогосподарство $€$ або активним учасником свого бізнесу здійснює пряме управління бізнесом через втручання у господарські процеси за напрямками діяльності, або пасивним - управління бізнесом передається довіреній особі, домогосподарство може здійснювати непрямий вплив на бізнес-процеси через таку особу, $є$ отримувачем доходів, але не бере безпосередньої участі у господарських процесах.

Відтак, підприємницьку діяльність домогосподарств пропонуємо трактувати як ініціативну, самостійну, інноваційно орієнтовану, здійснювану під власну відповідальність та під усвідомлений ризик діяльність з прямого або опосередкованого управління бізнесом, а також діяльність 3 виробництва, купівлі-продажу матеріальних і нематеріальних благ та формування економічних відносин з іншими суб'єктами господарювання на конкретних ринках, з метою отримання прибутку або досягнення інших економічних цілей.

Метою здійснення підприємницької діяльності домогосподарств будь-якого напрямку діяльності є отримання доходу, тому детальніше зупинимося на аналізі основних інтерпретацій цієї економічної категорії у сучасній науковій літературі. Сутність поняття «доходу» має загальний характер та концептуально визначає сутність поняття «доходи домогосподарств», яке $є$ більш локальним. Так, автори О. Попович та Н. Діденко стверджують, що економічна сутність доходів полягає у відшкодуванні витрат на ведення діяльності й отримання відповідної суми прибутку, яка забезпечує досягнення стратегічної мети - приросту власного капіталу, а логічне та структуроване визначення доходів дає можливість ефективно ними управляти та бути складовою сучасної системи управління» [4]. Як бачимо, авторами доречно наголошено на необхідності управляти доходами. Тобто можна говорити про те, що управління доходами є похідною «потребою» від глобального поняття «управління бізнесом» чи «управління підприємницькою діяльністю.

Кожне економічно свідоме домогосподарство, аналогічно як і підприємства, повинне прагнути до рентабельності, тобто збалансовувати доходи і витрати, нагромаджуючи та управляючи ресурсами тощо. Інакше кажучи, на відміну від підприємств, домогосподарство має більш широке, і не тільки економічне, але й соціальне значення. А потреба в управлінні доходами від підприємницької діяльності домогосподарств набуває необхідного значення. Як зазначає Р. Кові Стівен «...підприємства, суспільні групи, організації всіх видів (у тому числі родини) можуть бути проактивними. Проактивні індивіди мають здатність об'єднати свої творчість і винахідливість, щоб створювати всередині організацій проактивну культуру... А швидкі зміни у середовищі, в якому ми 
живемо, роблять потребу в ефективному лідерстві актуальною...» [5]. Можна сказати, що автор фактично наголошує на тому, що домогосподарство, поряд із іншими суб'єктами економіки, $є$ важливою рівноцінною економічною категорією, а його діяльність як підприємницька так і трудова, соціальна, побутова тощо потребує грамотного розуміння процесу управління. Фактично домогосподарство для того, щоб уміло генерувати управлінські рішення щодо певних бізнес-процесів повинне володіти набором компетенцій. Зокрема автори В. Брич та Х. Снігур в даному випадку акцентують увагу на необхідності володіти знаннями щодо методів здійснення впливу [6].

Також варто акцентувати увагу на спробах Л. Лілич та С. Мостенець обгрунтувати сутність управління доходами та видатками домогосподарств. Під управлінням доходами та видатками домогосподарств науковці розуміють «процес управління, формування і використання фондів фінансових ресурсів домогосподарств за допомогою специфічних прийомів і методів» [7].

Отже, проаналізувавши весь спектр наукових напрацювань щодо розуміння підприємницької діяльності домогосподарств, а також дослідивши наукові обгрунтування доходів домогосподарств, пропонуємо під поняттям «управління доходами домогосподарств від підприємницької діяльності» розуміти сукупність прямих та опосередкованих економічних дій суб'єкта господарювання щодо регулювання підприємницьких процесів та економічних відносин як всередині власної бізнес-системи (ФОП, підприємства тощо) так і на зовнішніх ринках з метою формування та ефективного використання прибутку або досягнення інших економічних цілей.

\section{Список використаних джерел:}

1. Станкевич, Ю. Ю. (2010). Домогосподарство в ринковій економічній системі та його відображення у світовій економічній думці XX століття (автореф. дис. ... канд. екон. наук). Київ.

2. Кізима, Т. О. (2011). Фінанси домогосподарств: концептуальні засади теорії і практики (дис. ... канд. екон. наук). Тернопіль.

3. Бутенко, Д. С. \& Довгопола, Ю. С. (2016). Шляхи розвитку підприємницької діяльності в Україні. Молодий вчений, (12), 682-685.

4. Попович, О. В. \& Діденко, Н. Ю. (2016). Тлумачення економічної сутності категорії «дохід». Економіка і суспільство, (7), 975-978.

5. Р. Кові Стівен. (2012). 7 звичок надзвичайно ефрективних людей. (О. Любенко, пер. з англ.). Харків: Книжковий Клуб «Клуб Сімейного Дозвілля».

6. Брич, В. Я. \& Снігур, Х. А. (2017). Акмеологічна модель фахівця нового типу. Демографрія та соціальна політика, (1), 124-131.

7. Лілич, Л. \& Мостенець, С. (2013). Управління доходами та видатками домогосподарств в умовах ринку. Інституційна економіка, (7). 47-53. 


\title{
ЗАКОНОДАВЧЕ РЕГУЛЮВАННЯ ІНОЗЕМНОГО IНВЕСТУВАННЯ В УКРАÏHI
}

\begin{abstract}
Псьота Тетяна Володимирівна
здобувач вищої освіти фракультету міжнародних економічних відносин та туристичного бізнесу Харківський національний університет ім. В. Н. Каразіна УКРАÏHA
\end{abstract}

Внутрішніми важелями контролю за транснаціональними інвестиційними потоками в Україні прийнято вважати низку законів, головними з яких є Закони України «Про інвестиційну діяльність», «Про режим іноземного інвестування».

Закон України «Про інвестиційну діяльність» закріплює рівні права щодо здійснення іноземними суб'єктами інвестиційної діяльності на території України. Інвестор зобов'язаний подати фрінансовим органам декларацію про обсяги і джерела здійснюваних інвестицій [1]. Згідно із Законом «Про режим іноземного інвестування», суб'єкти інвестування мають право визначати мету та способи ії реалізації, а також обсяги інвестицій; залучати будь-яких учасників інвестиційної діяльності на основі договорів. Для іноземних інвестицій було встановлено національний режим ведення підприємництва та спеціальні умови оподаткування [2].

Необхідно відзначити деякі негативні риси інвестиційної ситуації в Україні, що стає перешкодою для залучення більшого обсягу закордонних інвестицій у країну.

По-перше, інвестиційний клімат України характеризується низьким рівнем сприятливості ведення бізнесу міжнародними партнерами в нашій країні. Так, високим $€$ рівень бюрократизації, пов'язаний із урядовим контролем за веденням бізнесу, та корупції. За даними міжнародної неурядової організації Transparency International, у 2018 році Україна посіла 120 місце зі 180 за рівнем корумпованості економічного життя [3].

По-друге, існують високі некомерційні ризики, пов'язані із нестабільною політико-геостратегічним положенням України. Захисні механізми активів та прибутків потенційних інвесторів недостатньо розроблені в українському інвестиційному законодавстві.

Таким чином, постає необхідність у модернізації інвестиційної політики України у питанні регулювання іноземних інвестицій, а також покращення інвестиційного становища країни. Враховуючи досвід світових організацій 3 контролю міжнародних потоків інвестицій та високорозвинених країн і угруповань (США, Японії, Китаю, Європейського Союзу), автор вважає за доцільне здійснити зазначені нижче заходи:

1. Лібералізація законодавчих механізмів України у сфері інвестиційного права шляхом доповнення Законів України «Про інвестиційну діяльність», «Про режим іноземного інвестування» нормами про партнерську взаємодію державних органів та бізнесу. Даний крок дозволить будувати відносини між приватними інвесторами та Україною на принципах активного партнерства, що довело свою ефективність на прикладі інвестиційної політики Японії та США. У даній сфрері можливим $є$ зменшення надмірного регулювання діяльності іноземних підприємців завдяки корпоративним реформам у державних структурах, оптимізації кодексів України з економічних питань [4]. 
2. Активізація притоку іноземних інвестицій шляхом розширення пільгових термінів для закордонних інвесторів, зокрема у сфері венчурного бізнесу [5].

3. Створення інформаційних установ із консультативними функціями для забезпечення поінформованості іноземних інвесторів щодо економічного становища в Україні та процесу рефрормування інвестиційного законодавства України у цій сфері. Необхідним кроком у даній галузі $\epsilon$ розробка довгострокової програми покращення інвестиційного клімату України із подальшою інформаційно-комунікаційною програмою серед потенційних іноземних інвесторів на території України та за ії межами.

\section{Список використаних джерел:}

1. Про інвестииійну діяльність (Закон України). № 1561-XII. (1991). Вилучено 3 https://zakon.rada.gov.ua/laws/main/1560-12

2. Про іноземні інвестиції (Закон України). № 2198-ХІІ. (1992). Вилучено 3 https://zakon.rada.gov.ua/laws/main/2198-12

3. Transparency International, Corruption Perceptions Index 2018, Ukraine. Вилучено з https://www.transparency.org/country/UKR

4. Геєць, В. М. (2006). Інноваційні перспективи України. Харків: Константа.

5. Мартиненко, В. Ф. (2005). Державне управління інвестиційним процесом в Україні. Київ: Вид-во НАДУ.

DOI 10.36074/25.10.2019.v1.04

\section{ІНТЕЛЕКТУАЛЬНИЙ АНАЛІЗ ЯК МЕХАНІЗМ ВИЯВЛЕННЯ СХЕМНИХ ОПЕРАЦІЙ В УКРАЇНІ}

\section{НАУКОВО-ДОСЛІДНА ГРУПА:}

Кузьменко О.В. д-р. екон. наук, доцент, завідувач кафедри економічної кібернетики Сумський державний університет

Бойко А.O. канд. екон. наук, доцент, доцент кафедри економічної кібернетики Сумський державний університет

Яровенко Г.М., канд. екон. наук, доцент, доцент кафедри економічної кібернетики Сумський державний університет

Доценко Т.В., аспірант кафедри економічної кібернетики Сумський державний університет УКРÄ̈HA

Процесам розвитку сучасної економіки, притаманна трансформація фрінансової системи та стрімке зростання інформаційних технологій, що призводить до все більшого загострення проблем тіньового господарювання та легалізації коштів, отриманих незаконним шляхом. Вирішення цієї проблеми потребує впровадження ефективної системи оцінювання ризику використання 
фрінансових посередників з метою легалізації кримінальних доходів. Серед найсучасніших розробок у сфері протидії легалізації незаконних доходів особливого значення набуває інтелектуальний аналіз даних, а саме побудова нейронної мережі.

Для оцінювання ризику використання фінансових посередників з метою легалізації кримінальних доходів запропоновано реалізувати наступні етапи:

1. Формування статистичної бази дослідження. Сформовано набір даних по 215 країнам світу. Було обрано результативний показник - рівень ризику використання фінансових посередників з метою легалізації кримінальних доходів [1] та сім фракторних: валовий внутрішній продукт на душу населення; позови до центрального уряду; внутрішньо переміщені особи, нові переміщення, пов'язані 3 конфліктом та насильством (кількість випадків); банківська таємниця; індекс сприйняття корупції; глобальний індекс тероризму; світовий індекс щастя [2, 3, 4, 5, 6].

3 метою проведення такого методу інтелектуального аналізу даних, як виявлення ключових фракторів, запропоновано застосовувати програму Statistica, інструмент «Загальні лінійні моделі GLM».

2. Побудова нейронної мережі оцінювання ризику використання фрінансових посередників 3 метою легалізації кримінальних доходів. Формалізацію даного етапу запропоновано представити у вигляді багатошарового персептрону та мережі на основі радіальних базисних функцій.

Так, економіко-математична модель нейронної мережі досліджуваного ризику набуває вигляду (формула 1):

$$
f(x)=F\left(\sum_{i_{N}} w_{i_{N} j_{N} N} \cdots \sum_{i_{2}} w_{i_{2} j_{2} 2} F\left(\sum_{i_{1}} w_{i_{1} j_{1} 1} x_{i_{1} j_{1} 1}-\theta_{j_{1} 1}\right)-\theta_{j_{2} 2} \ldots-\theta_{j_{N} N}\right)
$$

de:

$F\left(\sum_{i_{1}} w_{i_{1} j_{1} 1} x_{i_{1} j_{1} 1}-\theta_{j_{1} 1}\right)-$ wap 1 ;

$\sum_{i_{2}} w_{i_{2} j_{2} 2} F\left(\sum_{i_{1}} w_{i_{1} j_{1} 1} x_{i_{1} j_{1} 1}-\theta_{j_{1} 1}\right)-\theta_{j_{2} 2}-$ map 2 ;

$F\left(\sum_{i_{N}} w_{i_{N} j_{N} N} \cdots \sum_{i_{2}} w_{i_{2} j_{2} 2} F\left(\sum_{i_{1}} w_{i_{1} j_{1} 1} x_{i_{1} j_{1} 1}-\theta_{j_{1} 1}\right)-\theta_{j_{2} 2} \ldots-\theta_{j_{N} N}\right)-$ uap $N$;

$i-$ номер входу;

$j$ - номер нейрону у шарі;

$x_{i_{1} j_{1} 1}-i$-ий вхідний сигнал $j$-го нейрону у шарі 1 ;

$w_{i_{N} j_{N} N}-$ ваговий коефічієнт i-ого вхідного сигналу ј-го нейрону у шарі $N$;

$\theta_{j_{N} N}-$ пороговий рівень $j$-го нейрону у шарі $N$.

В свою чергу, економіко-математична модель нейронної мережі ризику використання фрінансових посередників з метою легалізації кримінальних доходів у вигляді мережі на основі радіальних базисних функцій набуває вигляду [7, 8] (формула 2):

$$
f(x)=\sum_{i=1}^{N} w_{i} \varphi\left(\left\|x-x_{i}\right\|\right)
$$

de:

$w_{i}$ - ваговий коефіцієнт і-ого вхідного сигналу;

$x_{i}-$ центри радіальних базисних функцій.

Для побудови нейронної мережі типу багатошарового персептрону MLP використовується алгоритм Бройдена - Флетчера - Гольдфарба - Шанно 
(Broyden-Fletcher-Goldfarb-Shanno (BFGS)). Для побудови нейронної мережі на основі радіальних базисних функцій RBF використовується алгоритм RBFT. Для реалізації даного етапу пропонується використати можливості програми Statistica. Визначення вагових коефіцієнтів здійснено за допомогою методу найменших квадратів.

3. Економіко-математичне моделювання двох типів нейронних мереж (багатошарового персептрону MLP та мережі на основі радіальних базисних функцій RBF) регресійної залежності ризик використання фрінансових посередників з метою легалізації кримінальних доходів від релевантних регресорів.

Справедливо зазначити, що оцінювання ризику використання фінансових посередників з метою легалізації кримінальних доходів на основі нейронних мереж $€$ досить актуальним, потужним і гнучким інструментом забезпечення ефрективної системи державного контролю, враховуючи необхідність обробки великого об'єму даних. Цей метод дозволяє автоматично виявляти складні залежності економічних процесів, прогнозувати результати і мати можливість їх використовувати при прийнятті ефективних рішень у сфері державного управління. Впровадження такої методики дозволить передбачати та боротися зі злочинами пов'язаними з легалізацією доходів, одержаних злочинним шляхом і фрінансуванням тероризму.

Публікація містить результати досліджень, проведених за грантом Президента України за конкурсним проектом «Розробка прототипу автоматизованого модуля фрінансового моніторингу діяльності економічних агентів для протидії легалізації кримінальних доходів» (N держреєстрації 0119U103189). Публікацію підготовлено в межах виконання НДР «Кібербезпека в боротьбі з банківськими шахрайствами: захист споживачів фрінансових послуг та зростання фрінансово-економічної безпеки України» (N держреєстрації 0118U003574); НДР "Удосконалення національної системи протидії легалізації коштів, отриманих незаконним шляхом в контексті підвищення фрінансово-економічної безпеки держави» (N держреєстрації 0117U002251).

\section{Список використаних джерел:}

1. Lyeonov, S., Kuzmenko, O., Yarovenko, H. \& Dotsenko, T. (2019). The Innovative Approach to Increasing Cybersecurity of Transactions Through Counteraction to Money Laundering. Marketing and Management of Innovations, (3), 308-326. https://doi.org/10.21272/mmi.2019.3-24.

2. Happy Planet Index. (2017). Вилучено з http://happyplanetindex.org.

3. Institute for economics \& peace. (2017). Вилучено 3 http://visionofhumanity.org/app/uploads/2017/11/Global-Terrorism-Index-2017.pdf.

4. Organisation for Economic Co-operation and Development. (2017). Вилучено 3 https://data.oecd.org/?_ga=2.69359696.157983792.1546455347-1152323357.1544691649.

5. Transparency International. (2017). Вилучено 3: https://www.transparency.org/news/feature/corruption_perceptions_index_2017?gclid=EAlalQo bChMlusejy-PP3wIVVluyChONdwBEEAAYASAAEglyc_D_BwE.

6. World Bank Open Data. (2017). Вилучено з https://data.worldbank.org.

7. Powell, Michael J. D. (1977). Restart procedures for the conjugate gradient method. Mathematical Programming Journal. Springer, (12), 241-254. https://doi.org/10.1007/bf01593790.

8. Broomhead, David H. \& Lowe, David. (1988). Multivariable Functional Interpolation and Adaptive Networks. Complex Systems Journal, (2). 21-35. 


\title{
КОНКУРЕНТОСПРОМОЖНІСТЬ ПЕРСОНАЛУ ЯК ОСНОВНИЙ ЧИННИК ЕФЕКТИВНОЇ ДІЯЛЬНОСТІ ПІДПРИЄМСТВА
}

\author{
Ошийко Аліна Анатоліївна \\ студентка групи ФМБ-18-1 \\ Університет державної фріскальної служби України
}

Науковий керівник: Євтушенко Ганна Іванівна

канд. екон. наук, доцент кафедри менеджменту

Університет державної фріскальної служби України

УКРАÏHA

В умовах переходу України до ринкової моделі господарювання, руху у напрямі євроінтеграції, входження у міжнародний конкурентний простір та включення у світову економіку, перед вітчизняною економічною наукою i практикою ставляться принципово нові завдання, серед яких вагоме місце належить підвищенню конкурентоспроможності трудового потенціалу.

Успішне функціонування будь-якого виробництва залежить від раціонального використання трудового потенціалу, який розглядається як один з найважливіших стратегічних чинників, що сприяє ефективній реалізації цілей підприємства. Конкурентоспроможність підприємства - одна із найважливіших категорій ринкової економіки. Вона характеризує можливість ефективної адаптації до умов конкурентного середовища, що змінюється, шляхом раціонального використання наявних ресурсів підприємства [2, с.78]. Досягнення успіху підприємством стратегічно обумовлюється наявністю компетентного персоналу, що має належний рівень освіти, кваліфрікації та досвіду й здатного ефективно працювати в умовах ринку.

Конкурентоспроможність персоналу - це складна економічна категорія, що визначає здатність працівників генерувати ідеї, розробляти й швидше за конкурентів впроваджувати інновації, якнайкраща відповідність вимогам роботодавців за рівнем знань, умінь, навичок, спроможність найкращим чином докладати особистісні, професійні та ділові якості й повною мірою реалізувати власний потенціал, а також вміння ефективно виконувати управлінські функції та своєчасно приймати рішення [1].

Розглядаючи конкурентоспроможність працівника як якісний показник, можна сегментувати найманих працівників за рівнем їхньої потенційної і фактичної ефективності праці і здатності до професійного розвитку. Відповідно при відборі працівників враховується найбільша відповідність їхнього людського капіталу та якості праці до вимог роботодавця, що дозволяє визначити здібних.

На рівні з якістю існують дуже важливі кількісні й вартісні характеристики робочої сили такі, як, наприклад, продуктивність праці, вклад робітника у фрінансові результати підприємства, ефективність використання робочої сили, вартість робочої сили, витрати на розвиток робочої сили.

Конкурентоспроможність персоналу забезпечується не лише за рахунок вмілого використання індивідуальних конкурентних переваг, але також за рахунок ефективної системи управління персоналом та системи менеджменту 
підприємства. Поліпшення показників оцінки трудового потенціалу безпосередньо позитивно відбивається на показниках діяльності підприємства, а саме: збільшується прибуток, з'являються сприятливі умови для підтримки, посилення існуючих та формування конкурентних переваг підприємства, розвитку на підприємстві інноваційної та інвестиційної діяльності та ефективному використанні та розвитку стратегічного потенціалу підприємства на чолі з людськими ресурсами, технікотехнологічними, інформаційними, фрінансовими, матеріальними та іншими ресурсами.

На сьогоднішній день підприємство повинно сприяти розвитку найманих працівників. Здатність підприємства навчатися і розвиватися швидше за своїх конкурентів $є$ джерелом його соціальних, стратегічних і економічних переваг. Успішний розвиток персоналу вимагає використання конкретних заходів, спрямованих на формування й активізацію його знань, можливостей i поведінкових аспектів, які повинні враховуватися при виборі кадрової стратегії, обґрунтованої кадрової політики, реалізуватися в проектах розвитку персоналу з використанням сучасних методів та механізмів [3]. Професійний розвиток особистості та підвищення конкурентоспроможності, розвиток працівників належать до основних показників прогресивності суспільства, вирішальних важелів науково-технічного прогресу. Тому в країнах 3 розвинутою ринковою економікою дедалі більше компаній перебирають на себе ініціативу щодо подальшого розвитку персоналу своїх організацій [4].

Крім того, сьогодні на багатьох підприємствах України, як правило, управління персоналом розглядається окремо від обов'язкової вмотивованості працівників на досягнення кінцевої мети організації, які повинні усвідомлювати залежність від цього свого добробуту та особистої конкурентоспроможності. Тому потребує створення особлива модель мотивації праці, яка враховує чинники зовнішнього та внутрішнього середовища, соціально-психологічний вплив яких змінює мотиви людини до праці.

Одже, для підвищення конкурентоспроможності трудового потенціалу підприємства, запропоновано наступні заходи:

1. Для підвищення конкурентоспроможності працівник повинен прагнути розширювати свої знання і кваліфікацію як у цій сфері діяльності, так і в інших copepax.

2. Для забезпечення конкурентоспроможності персоналу, особливу увагу слід приділити мотивації працівників в досягненні цілей підприємства. Для цього необхідне широке впровадження в практику управління персоналом програм залучення працівників до управління виробництвом; робота в цільових групах по розробці перспективних спеціальних проектів; горизонтальні ротації в рамках фірми і її фрілій, у тому числі закордонних та ін.

3. Велике значення для забезпечення підприємства ефективним персоналом має попередня професійна діагностика. Проведення регулярної діагностики не тільки нового персоналу, але й постійного, дозволить визначати пріоритети розвитку працівників, прогнозувати і планувати їх кар'єру, i , таким чином, сформувати у працівників мотивацію до розвитку необхідних підприємству компетенцій, що без сумніву буде сприяти зростанню конкурентоспроможності трудового потенціалу персоналу [1]. 
$34 \bullet$ Scientific discoveries: projects, strategies and development $\bullet$ Volume 1

Планування та організація розвитку працівників стають важливими фуннкціями служби управління персоналом. Наслідування Україною цього прикладу $\epsilon$ обов'язковою умовою забезпечення в державі сталого економічного зростання. Саме тому, питанням підвищення конкурентоспроможності персоналу потрібно приділяти велику увагу, тому що це безпосередньо впливає на кінцеві результати діяльності підприємства в цілому.

\section{Список використаних джерел:}

1. Арапова, О. М. (2009). Конкурентоспроможність персоналу та її значення у діяльності підприємства. Ефективна економіка, (3). Вилучено 3 http://www.economy.nayka.com.ua/?op=1\&z=42.

2. Бурлаєнко, Т. І. (2015). Формування економічної компетентності менеджерів освіти як складової функціонально-посадової компетентності. Нові технології навчання, (84), 77-82.

3. Бучинська, Т. В. (2017). Конкурентоспроможність персоналу як основний чинник підвищення ефрективності діяльності підприємства. Науковий вісник Ужгородського національного університету. Серія: Міжнародні економічні відносини та світове господарство, 10(1), 477.

4. Про обмеження монополізму та недопущення недобросовісної конкуренції у підприємницькій діяльності (Закон України) (1992).

\section{МАРКЕТИНГОВІ ІНТЕРНЕТ-ТЕХНОЛОГІЇ В АГРАРНОМУ СЕКТОРІ УКРАÏНИ}

Рябчик Алла Володимирівна

канд. екон. наук, доцент, доцент кафедри маркетингу та міжнародної торгівлі Національний університет біоресурсів і природокористування України УКРӒ̈HA

Впровадження та розвиток маркетингових інтернет-технологій - одне із найбільш актуальних та важливих питань сьогодення. Незалежно від спеціалізації, позиції на ринку, конкурентних переваг та розмірів, будь-яке підприємство отримує можливості доступу до світового ринку, нових інструментів та засобів просування продукції на ринках, різноманітних способів взаємодіяти зі споживачами, більш повно задовольняти їх потреби. Інтернет та сучасні інтернет-технології також трансформували спосіб поведінки споживачів, взаємодії, спілкування та придбання споживачами продукції. Доступність різноманітної інформації та даних стали не лише діловою реальністю, але й реальністю кожного споживача. В таких умовах, Інтернетмаркетинг та інтернет-технології $€$ не лише інноваційним інструментом ведення бізнесу, а й базовим компонентом розвитку та ефективного функціонування.

Інтернет-маркетинг - це маркетингова діяльність в мережі Інтернет з метою визначення та задоволення потреб і бажань споживачів, управління 
взаємостосунками з ними та досягнення цілей підприємства. В науковій літературі, зазвичай, не дається окремого визначення терміну «маркетингові інтернет-технології». Під цим терміном мається на увазі практичне застосування всіх інноваційних інструментів, новітніх методів та технологій Інтернет-маркетингу, які використовують підприємства для просування своїх товарів та послуг на ринку. На думку науковців С. Міхнєєвої та Г. Маркєєвої, до таких технологій відносяться: створення веб-сайту; інтернет-реклама; вірусний маркетинг; мобільний маркетинг; пошуковий маркетинг; emalмаркетинг; он-лайн ігри; відео-маркетинг; маркетинг соціальних зв'язків; формування громадської думки [1].

Повний набір маркетингових інтернет-технологій, які ми пропонуємо для підприємств аграрного сектору, зображено на рисунку 1. Вибір окремих із них та практичне їх використання залежить від розмірів підприємства, його спеціалізації, видів продукції, що виробляється, та фінансових можливостей. Деякі із цих технологій вимагають значних фрінансових ресурсів, інші можна застосовувати з мінімальним бюджетом на Інтернет-маркетинг.

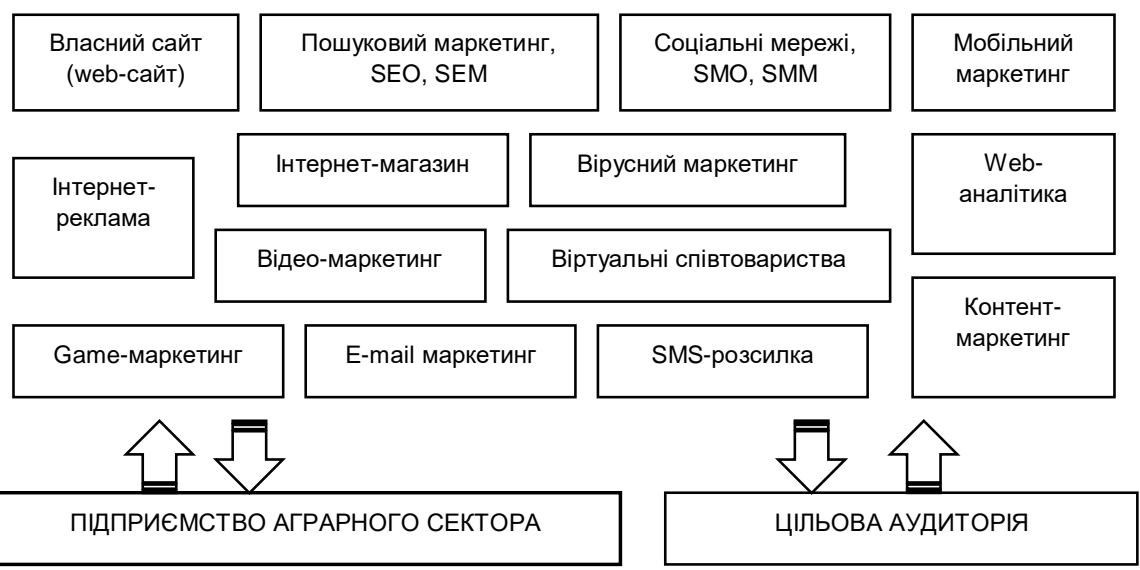

Рис. 1. Маркетингові інтернет-технології для підприємств аграрного сектору України

Не дивлячись на динамічне зростання інформаційних технологій, впровадження маркетингових інтернет-технологій в аграрному секторі України знаходиться ще на стадії становлення. Це пов'язано з низьким ступенем проникності Інтернету, недостатньою обізнаністю про переваги і можливості Інтернет-маркетингу, невідповідністю матеріально-технічного забезпечення господарюючих суб'єктів аграрного сектора, недостатністю кадрового та науково-методичного забезпечення, низьким рівнем комп'ютерної грамотності, нестачею фінансових ресурсів, невідповідним ставленням і регулюванням держави даної галузі та проблемами впровадження сучасних інноваційних та новітніх інформаційних технологій в аграрному секторі України в цілому. 
Розуміння маркетингових інтернет-технологій та всіх їх можливостей - це необхідність та сутність маркетингової діяльності (стратегії) підприємств аграрного сектору нової епохи. Успішна стратегія Інтернет-маркетингу вимагає інтегрованої кампанії, співпраці та координації всіх дій і фахівців, щоб уникнути генерування повторюваного чи невідрегульованого контенту, не узгодженого із загальною маркетинговою метою та маркетинговими цілями.

Ефективними елементами контент-маркетингу в аграрному секторі є: унікальний контент з історіями та деталями, який розкриває клієнтам окремі аспекти агробізнесу; персоналізація авторів контенту; створення медіа-каналу; показ креативних графічних презентацій, фотографій; розповіді у блогах про цілі і принципи агровиробництва, а також про проблеми та інновації аграрного сектору; використання інфоографіки та інші [2].

При плануванні стратегії Інтернет-маркетингу та маркетингових інтернеттехнологій кожне підприємство аграрного сектору має зосередитися на раціональних та емоційних вигодах. Також потрібно враховувати наступні загальні принципи та рекомендації: кожне сучасне підприємство повинно мати власний веб-сайт; веб-сайт підприємства повинен бути оптимізований для використання настільними ПК, планшетами, смартфонами; унікальне повідомлення $є$ конкурентною перевагою; комунікація має бути створена відповідно до різних інтересів цільових аудиторій; розробка всіх повідомлень $€$ важливою частиною спілкування та привернення уваги; блоги $є$ ефективним інструментом для підтримки зв'язку з клієнтами; спілкування через відео та пряму трансляцію є досить ефективним в онлайн-спілкуванні; взаємодія 3 клієнтами через соціальні медіа є необхідністю; публічні профілі співробітників повинні відповідати організаційному іміджу та інтересам; відслідковування інтересів клієнтів та постійна адаптація.

В загальному, згідно до Jones та ін., $є$ три загальні основні принципи Інтернет-маркетингу, які мають вирішальне значення для успіху на віртуальному ринку: (1) безпосередність із своєчасним реагуванням на аудиторію; (2) персоналізація; (3) відповідність інформації [3].

Отже, інтернет-технології зрушили межі у відносинах «підприємствоклієнт» і повністю трансформували управлінські та організаційні процеси. Залучення до спектру маркетингових інтернет-технологій $є$ необхідністю для підприємств аграрного сектору в сучасних умовах конкурентного середовища, оскільки відкривають безліч можливостей - доступ до глобального ринку, підвищення авторитетності підприємства на ринку, створення конкурентних переваг, адресність звернення, можливість точної, оперативної оцінки ефективності маркетингових заходів, управління подіями в режимі реального часу та багато іншого. 3 іншої сторони, впровадження маркетингових інтернеттехнологій $є$ непростим завданням. Завдяки постійно змінюваним продуктам, послугам і технологіям своєчасне реагування та прийняття нової ринкової реальності (з досягненням найвищого рівня задоволеності споживачів) вимагає значних навичок та зусиль. Крім того, інтернет-аудиторія $€$ «вибагливою, фрагментарною та цинічною» більше, ніж будь-коли [4]. Сучасні клієнти вимогливі до вмісту та досвіду, який вони отримують від підприємств, а також зацікавлені в активній взаємодії. Віртуальний світ надає багато можливостей для вдосконалень, креативних стратегічних підходів та 
ефективного функціонування, і лише від підприємства залежить, як цим скористатися.

\title{
Список використаних джерел:
}

1. Михнеева С. \& Маркеева, Г. (2015). Технологии интернет-маркетинга как современный инструмент продвижения бизнеса. Известия высших учебных заведений. Серия "Общественные науки», 1(33), 239-247.

2. Симонова А. (2019). 10 ярких примеров контент-маркетинга в аграрной индустрии. Вилучено 3 https://netpeak.net/ru/blog/10-yarkikh-primerov-kontent-marketinga-v-agrarnoyindustrii/.

3. Jones, A. T., Malczyk, A. \& Beneke, J. (2013). Internet marketing. GetSmarter, Cape Town.

4. Yung, R. (2013). A Comprehensive Step-By-Step Guide to Internet Marketing: The Building Blocks for succeeding with Marketing on the Web. New Jersey: BookBaby.

\section{ОСОБЛИВОСТІ УПРАВЛІННЯ КАДРАМИ В СУЧАСНИХ УМОВАХ}

\begin{abstract}
Захарова Катерина Володимирівна
здобувач вищої освіти економічного факультету

Запорізький національний університет

Науковий керівник: Малтиз Вікторія Віталіївна

канд. екон. наук, доцент кафедри управління персоналом і маркетингу

Запорізький національний університет

УКРӒ̈HA
\end{abstract}

На сьогоднішній час питанням управління кадрами приділяється все більше уваги. Проблеми зростання рівня ефективності виробництва і вирішення задач, пов'язаних 3 підвищенням конкурентоспроможності, рентабельності підприємства, його стабільності пов'язані головним чином 3 якісним складом кадрів, трудовим потенціалом персоналу. Перспективи розвитку підприємства, крім головної економічної складової, безпосередньо залежать від ступеня залученості персоналу в процеси вдосконалення організації.

Активність керівництва в питаннях управління кадрами безпосередньо пов'язана з економічним становищем підприємства. Для підприємства, що знаходиться на стадії виживання, характерно, що управління персоналом не розглядається в якості проблемної зони, що вимагає спеціальних зусиль з боку менеджерів. Вихід з кризової ситуації означає зміну орієнтирів кадрового менеджменту, націленої на позитивну динаміку в розвитку виробництва. В інтересах раціоналізації виробничого процесу пріоритети кадрової політики можуть обиратися різні, але загалом вони пов'язані з якістю людських ресурсів [1]. Актуальними в кадровій політиці стають збереження кваліфікованих і лояльних працівників; збільшення частки молоді у віковому складі персоналу; організація зайнятості, що забезпечує закріплення професійних кадрів, гнучкість режиму праці і відпочинку. 
Новостворені підприємства, так само як і ті, що мають тривалий період діяльності, зосереджують увагу на якості людських ресурсів, але кадрові пріоритети стають все більше наближеними до західних цінностей. Серед принципів кадрової політики сучасних підприємств виділяють наступні:

- підбір і закріплення висококваліфрікованих, освідчених фрахівців, здатних до навчання та інтенсивної роботи;

- постійне підвищення рівня компетентності персоналу;

- формування згуртованого колективу, здатного працювати «як єдиний механізм» [2].

Інновації в управлінні персоналом відбуваються слідом за зміною загального проекту і структури управління у випадках зміни власника, входження підприємства в холдинг. Індикаторами зрушень виступають зміна пріоритетів в управлінні: від виробничих підрозділів до ринкових; перехід на більш високий рівень технологій; поява молодих професіоналів-управлінців.

Висновки. Успіх розвитку будь-якої організації, незалежно від виду і масштабів ії діяльності, безпосередньо залежить від ефективності роботи кадрів. Висококваліфікований і компетентний персонал, задоволений умовами і заробітною платою, демонструє високу продуктивність праці. Тому ефективно організований процес набору, оцінки, розподілу і мотивації персоналу сприяє досягненню поставлених керівництвом організації цілей.

\section{Список використаних джерел:}

1. Марченко, В. М. (2017). Кадрова політика та кадрова стратегія підприємства. Глобальні та національні проблеми економіки, (20), 440-443. Вилучено 3 https:/globalnational.in.ua/archive/20-2017/89.pdf.

2. Бучинська, Т. В. (2016) Конкурентоспроможність персоналу як основний чинник підвищення ефрективності діяльності підприємства. Науковий вісник Ужгородського національного університету, (10(1)), 74-77.

\section{ОЦІНА СУЧАСНОГО СТАНУ ДЕРЖАВНОГО БОРГУ УКРАїНИ}

Лаб'як Ганна Василівна

студентка

Коледж Чернівецького національного університету імені Юрія Федьковича

Томашевська Альона Миколаївна

викладач

Коледж Чернівецького національного університету імені Юрія Федьковича

УКРӒ̈HA

Державний борг є важливою складовою фрінансової системи. Він виступає дієвим інструментом у механізмі макроекономічного регулювання, забезпечення додатковими ресурсами і засобом реалізації економічної стратегії держави. 
Державний борг - загальна сума боргових зобов'язань держави 3 повернення отриманих та непогашених кредитів (позик) станом на звітну дату, що виникають внаслідок державного запозичення» [1].

Питання проблеми фрормування державного боргу в Україні та всі процеси пов'язані з ним на сьогодні $є$ дуже актуальними, адже з кожним роком боргові зобов'язання України зростають і, відповідно, зростають витрати на його управління та обслуговування.

Досвід багатьох країн свідчить про те, що державний борг у певних розмірах не має негативних наслідків для господарства країни. Але надмірний державний борг може призвести до серйозних негативних наслідків для економіки, які уповільнять її розвиток і спричинять зменшення доходів населення [3].

На сьогодні одним із факторів, який суттєво стримує економічний розвиток України $є$ подальше зростання обсягу державних запозичень. Тому проведення постійного моніторингу за обсягом та структурою державного боргу, механізмом його обслуговування та погашення $\epsilon$ актуальною проблемою.

Обсяг державного боргу України за 2015 - 2018 роки має зростаючу динаміку: у 2018 році його загальна сума зросла на 26,7 млрд. грн., а темп приросту становив 1,2\%, порівняно з 2017 (табл. 1).

Таблиця 1

Обсяг та структура державного боргу України за 2015 - 2018 роки

\begin{tabular}{|c|c|c|c|c|c|c|c|c|c|}
\hline \multirow{3}{*}{ Показник } & \multicolumn{8}{|c|}{ Роки } & \multirow{3}{*}{\begin{tabular}{|c|}
$\begin{array}{c}\text { Темп } \\
\text { приросту, } \\
\%\end{array}$ \\
у 2018 \\
\end{tabular}} \\
\hline & \multicolumn{2}{|c|}{2015} & \multicolumn{2}{|c|}{2016} & \multicolumn{2}{|c|}{2017} & \multicolumn{2}{|c|}{2018} & \\
\hline & млрд. грн. & $\%$ & млрд. грн. & $\%$ & млрд. грн. & $\%$ & $\begin{array}{l}\text { млрд. } \\
\text { грн. }\end{array}$ & $\%$ & \\
\hline $\begin{array}{l}\text { Державний } \\
\text { борг (прямий), } \\
\text { з нього: }\end{array}$ & 1333,9 & 84,8 & 1650,8 & 85,5 & 1833,7 & 85,6 & 1860,3 & 85,8 & 1,5 \\
\hline $\begin{array}{l}\text { - внутрішній } \\
\text { борг }\end{array}$ & 508,0 & 32,3 & 670,6 & 34,7 & 753,4 & 35,2 & 761,1 & 35,1 & 1,0 \\
\hline $\begin{array}{l}\text { - зовнішній } \\
\text { борг } \\
\end{array}$ & 826,3 & 52,6 & 980,2 & 50,8 & 1080,3 & 50,4 & 1099,2 & 50,7 & 1,7 \\
\hline $\begin{array}{l}\text { Гарантований } \\
\text { державою } \\
\text { борг з нього: } \\
\end{array}$ & 237,9 & 15,2 & 278,9 & 14,5 & 308,0 & 14,4 & 308,1 & 14,2 & 0,03 \\
\hline $\begin{array}{l}\text { внутрішній } \\
\text { борг } \\
\end{array}$ & 21,5 & 1,4 & 19,1 & 1,0 & 13,3 & 0,6 & 10,3 & 0,5 & $-22,6$ \\
\hline $\begin{array}{l}\text { - зовнішній } \\
\text { борг }\end{array}$ & 216,5 & 13,8 & 259,8 & 13,5 & 294,7 & 13,8 & 297,8 & 13,7 & 1,1 \\
\hline $\begin{array}{l}\text { Загальна сума } \\
\text { боргу }\end{array}$ & 1572,2 & 100 & 1929,8 & 100 & 2141,7 & 100 & 2168,4 & 100 & 1,2 \\
\hline
\end{tabular}

дані сформовано з [5]

Протягом досліджуваного періоду, найбільшу частку боргу України займає прямий державний борг, тобто позичальником виступала держава. Так, у 2015 році його частка складала 84,8\% від загальної суми; 2016 - 85,5\%; 2017 85,6\%; 2018 - 85,8\%, як бачимо, динаміка частки є зростаючою.

Якщо розглядати окремо структуру державного прямого боргу, то 
найбільша частина припадає на зовнішній борг: 2015 - 52,6\%; 2016 - 50,8\%; $2017-50,4 \% ; 2018-50,7 \%$.

Гарантований борг України у 2015 році займав 15,2\%; 2016 - 14,5\%; 2017 - 14,4\%; 2018 - 14,2\%, тобто, динаміка частки є спадаючою.

Стрімке зростання державного (прямого) боргу та гарантованого державою боргу відбулося у 2016 - 2017 роках (рис. 1).

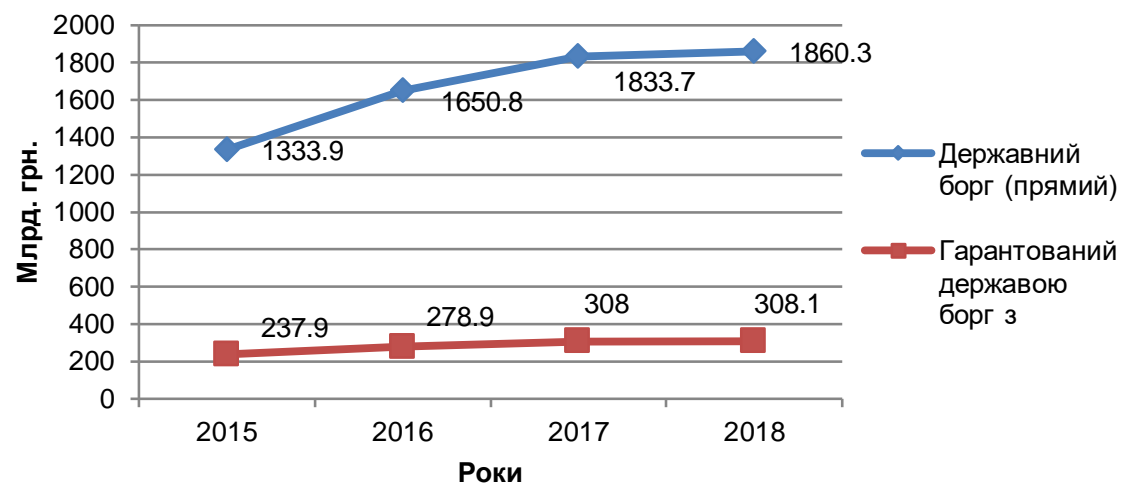

\section{Рис 1. Динаміка державного боргу та гарантованого державою боргу України за 2015 - 2018 роки}

Основними причинами, які призвели до значного зростання державного i гарантованого державою боргу України в 2016 - 2017 роках стали:

- необхідність нарощування валютних резервів, які значно вичерпалися валютною інтервенцією Національного банку України;

- залежність України від імпорту енергоносіїв;

- технічна відсталість значної частини сфер національної економіки;

- політичний стан країни;

- використання державних запозичень для покриття дефріциту державного бюджету, зумовленого збільшенням видатків на оборону та обслуговування державного боргу; банків [2].

- необхідність потужної державної підтримки державних підприємств та

Для модернізації боргової політики України велике значення має пошук вигідних та ефективних умов запозичень кредитних ресурсів за критеріями мінімізації витрат на обслуговування та вартості розміщення. За рахунок досягнення цієї стратегічної цілі досягається економія коштів державного бюджету, а також запускається процес стимулювання інвестиційної діяльності, зростання середнього рівня добробуту за рахунок пожвавлення темпів економічного зростання та проведення структурної перебудови національної економіки [4].

Висновки. Проведе дослідження показує, що сучасний стан боргової політики України $є$ вкрай негативним, адже в умовах нестачі коштів держава не в змозі виконувати свої боргові зобов'язання, в результаті чого вимушена використовувати нові запозичення. 
На сьогодні в Україні повинна бути вироблена стратегія з питань залучення державних запозичень та управління ними на основі узгодження між собою бюджетної, валютної, грошово-кредитної, інвестиційної та податкової політики. В умовах загрозливого стану боргової безпеки першочерговим повинна бути розробка довгострокових планів залучення i управління державними запозиченнями, де мають міститися напрями залучення коштів та критерії ефективності їх використання.

Також, управління державним боргом потребує досконалого правового забезпечення щодо формування боргових зобов'язань, механізму їх управління, обслуговування і погашення в умовах, які склались в Україні на сучасному етапі, при цьому, уряду України необхідно реально вивчити картину обсягів державних запозичень, розробити механізм ефрективного використання позичкових коштів та контролювати додержання оптимальної структури боргу.

\section{Список використаних джерел:}

1. Бюджетний кодекс України (Відомості Верховної Ради України), № 50-51, ст. 572. (2010). Вилучено з http://zakon.rada.gov.ua/laws/show/2456-17.

2. Дем'янчук, М. А. \& Коба, О. С. (2016). Дослідження впливу державного боргу і десріциту бюджету на національну економіку. Фінансові аспекти розвитку держави, регіону та суб'єктів господарювання: сучасний стан та перспективи (с. 185-187). Одеса, Україна.

3. Макар, О. П., Ільницька-Гикавчук, Г. Я. \& Дулин, І. С. (2013). Світовий досвід управління державним боргом та перспективи його застосування в Україні. Ефрективна економіка, (10), Вилучено 3 http://www.economy.nayka.com.ua/?op=1\&z=2435.

4. Омеляненко, М. О. (2018). Модернізація політики управління державним боргом України. Вилучено 3 http://www.investplan.com.ua/?op=1\&z=5867\&i=8.

5. Офріиійний сайт Державної казначейської служби України. Вилучено з http://www.treasury.gov.ua/main/uk/index.

\section{ПОГЛЯД НА ОБЛІКОВО-АНАЛІТИЧНЕ ЗАБЕЗПЕЧЕННЯ БІЗНЕС-ПЛАНУ}

Болваненко Людмила Володимирівна

викладач економічних дисциплін

Коледж ракетно-космічного машинобудування Дніпровського національного університету імені Олеся Гончара

Сітарчук Валерія Валеріївна заступник директора з виховної роботи, викладач економічних дисциплін Коледж ракетно-космічного машинобудування Дніпровського національного університету імені Олеся Гончара

УКРÄ̈HA

Розвиток української національної економіки зумовлює наявність у підприємства системи надання обліково-аналітичної інформації. Для того, щоб бізнес-планування на підприємстві мало успіх, необхідно щоб були умови, котрі будут взаємопов'язані і складуть механізм процессу бізнес-планування. 
Бізнес-планування - це побудова плану, способу майбутніх дій, визначення економічного змісту і послідовних дій, які ведуть до поставленої мети [1].

Коли Україна почала переходити до ринкових відносин, то таке поняття як планування фактично счезло. Почали думати, що ринкові відносини розставлять все по своїх місцях.

Сьогодні ввіжається, що бізнес-планування $€$ однією 3 найважливіших функцій менеджменту на будь-якому підприємстві. Бо сааме з бізнеспланування починається вибудовування та фрункціонування суб'єкта господарювання [3].

Саме з бізнес-планування починається як створення, так і функціонування господарського суб'єкта. Якщо недооцінювати бізнес-планування в ринкових відносинах, то це призведе до економічного спаду. Бізнес-план $\epsilon$ рекомендацією до виконання. Він $є$ підставою для фрінансового забезпечення підприємства. При цьому план необхідний не тільки великим і середнім підприємствам, але й малим підприємствам.

Ефективність бізнес-плану значною мірою визначається раціональність побудови при його розробці і застосуванню відповідних процедур.

При розробці бізнес-плану підприємствам необхідно звертати увагу на те, що, хоча і офріційних вимог до оформлення бізнес-плану не встановлено, існують неформальні вимоги, котрі необхідно враховувати.

Бізнес-план є документом, котрий містить в просторі і часі узгоджені з метою і ресурсами заходів і дії, направлених на отримання прибутку, внаслідок реалізації підприємницького проекту. Це результат планування, зафіксований в стислій і зрозумілій формі документ. Він виступає інструментом досягнення мети, котра включає в себе всі основні направлення діяльності підприємства. Мета розробки бізнес-плану полягає в формуванні розвитку організації, котра забезпечує оцінку і аналіз дій підприємства в умовах невизначеності.

Обліково-аналітичне виконання бізнес-плану супроводжується шляхом прийняття і виконання рішень в керівництві організацією. Воно забезпечує проведення розробки, оперативної діяльності, перевірки, оцінки результатів та ефективність діяльності. Без обліку та аналітичного супроводження фактично неможлива реалізація ні однієї з функцій ділового адміністрування [2].

Складність створення обліково-аналітичного представлення бізнес-плану багато в чому обумовлена особливостями організаційного і економічного положення підприємства. Система обліково-аналітичного забезпечення бізнес-плану базується на фракторах (конкуренція, інновації, культура), котрі можуть вступати у взаємодію.

В залежності від характеристик організації систему обліково-аналітичного виконання бізнес-плану можна умовно поділити на шість розділів: методичний, організаційний, проектний, аналітичний, ресурсний, програмний і контрольний.

Методичний блок визначає базові підходи проведення процедур обліковоаналітичного управління бізнес-плану. Він включає інструкції, типові методики, єдині критерії для діагностики.

Проектний блок включає систему взаємопов'язаних по змісту, ресурсам, термінах і місцях проведення заходів, направлених на досягнення єдиної цілі і задачі. 
В ході проектування обліково-аналітичного забезпечення складаються бізнес-плани, котрі забезпечують проведення аналізу по проблемах, котрі вимагають більш глибокого вивчення, містять об'єкти, суб'єкти, етапи, строки проведення аналізу. Вони включають перелік об'єктів аналізу, який підлягає вивченню.

Програмно-аналітичний блок об'єднує комплекс програмних засобів, які організують обліково-аналітичне забезпечення бізнес-плану. Цей блок забезпечує обробку вхідної та вихідної інформації. При цьому від систематичного забезпечення інформацією залежить як поточний успіх організації, так і наступні її фрінансові результати.

Результативність обліково-аналітичного забезпечення бізнес-плану в багатьох залежить від правильного його складання, котрий повинен відповідати ряду вимог.

Бізнес-план - це документ, який дає розвернуте виправдання проекту i можливість різноманітно оцінити ефективність прийнятих рішень, планованих заходів, відповісти на питання, чи варто вкладати гроші в даний проект [1].

Важливим етапом в розробці бізнес-плану $\epsilon$ розробка плану, котрий необхідний як для внутрішньо фірмового планування, так і для отримання фінансових ресурсів з зовнішнього джерела, тобто отримання грошових коштів під конкретний проект у вигляді банківських позичок, бюджетних асигнувань, пайової участі інших організацій в здійсненні проекту.

В бізнес-плані відображені всі сторони виробничої і комерційної діяльності організації, її фінансові результати.

В розробці бізнес-плану найважливіша частина - фрінансова, котра ґрунтується на аналізі та оцінці грошових потоків, генерованих фрінансовогосподарською діяльністю підприємства, розрахунку основних показників їх ефективності.

Вдосконалення процесу обліково-аналітичного забезпечення бізнес-плану передбачає формуванні інформаційних потреб, збір та обробку інформації, передачу інфрормації у зручному вигляді для користувачів, подальшу її раціональну обробку.

Сучасна система обліково-аналітичного забезпечення бізнес-плану повинна орієнтуватися на покращення наявного обсягу інформації. Така система повинна забезпечувати можливість порівняння планових цифр 3 фрактично досягнутими значеннями. Така система необхідна як для координації системи планів, так і для представлення інформації, необхідної для керування підприємством. За результатами порівняння встановлюються причини відхилень, усуваються помилки і розробляються корегуючи заходи.

\section{Список використаних джерел:}

1. Білоусова, І. А. (2010). Управлінський облік - інформаційна складова системи економічної безпеки підприємства. Київ: Дорадо-Друк.

2. Мартюшева Л. С., Кузенко, Т. Б. \& Литовченко, О. Ю. (2008). Фінансова безпека підприємств. Харків: ХНЕУ.

3. Поддєрьогін, А. М. (ред.). (2004). Фінанси підприємств. (5-те вид., перероб. та доп.). Київ: KHEY. 
DOI 10.36074/25.10.2019.v1.05

\title{
УДОСКОНАЛЕННЯ ІНФОРМАЦІЙНО-АНАЛІТИЧНОГО ЗАБЕЗПЕЧЕННЯ УПРАВЛІННЯ ЕКОНОМІЧНИМ ПОТЕНЦІАЛОМ ТА ЕКОНОМІЧНОЮ ПОТУЖНІСТЮ
}

\begin{abstract}
Дзюба Тетяна Ігорівна
аспірант кафедри статистики та економічного аналізу Національний університет біоресурсів і природокористування України
\end{abstract}

УКРӒ̈̈А

Удосконалення інформаційно-аналітичного забезпечення управління економічним потенціалом та економічною потужністю $є$ актуальною задачею підтримки процесу управління господарюванням виробників сільськогосподарської продукції України.

Оптимальний аналіз діяльності сільськогосподарських підприємств може бути здійснений різними способами. Поточне дослідження зосереджує свою увагу на таких показниках як економічний потенціал та економічна потужність [2].

Економічною потужністю підприємства $€$ «такий річний обсяг виготовленої продукції (продуктивність робіт), коли величина річного прибутку відповідає нормативному значенню - рентабельності продукції, що закладають у ціну» [1]. Методика оцінки цього показника залежить від мети дослідження і виду досліджуваного підприємства, зокрема, економічна потужність може бути розглянута у вигляді економічної або фрінансової доданої вартості [3; 4].

Виходячи з ідеї, що економічна потужність аграрного підприємства $є$ економічним потенціалом, обмеженим певними зовнішніми та внутрішніми умовами господарювання, логічно припустити, що порівняння цих показників дасть можливість оцінити поточну результативність діяльності аграрного підприємства [2].

Для удосконалення інформаційно-аналітичного забезпечення управління економічним потенціалом та економічною потужністю пропонуємо використовувати коефіцієнт економічної результативності діяльності підприємства, який розраховується діленням показника економічної потужності на показник економічного потенціалу:

$$
k \mathrm{Ep}=\frac{\mathrm{E}_{\Pi-\mathrm{T}}}{\mathrm{E}_{\Pi-л}}
$$

У результаті розрахунку коефіцієнт економічної результативності може набувати значення від 0 до 1. Чим більше значення коефріцієнту, тим потужніше підприємство реалізує власний економічний потенціал, тобто оптимальніше управляє економічним потенціалом в поточних умовах діяльності. Потрібно зазначити, що для застосування запропонованої методики необхідно використовувати однотипні методики та вимірники показників економічного потенціалу та економічної потужності. 
На основі огляду розрахованої економічної результативності можна зробити висновок про те, наскільки ефективно був реалізований економічний потенціал аграрного підприємства в поточний період. Також можна оцінити, яку долю від потенціального прибутку (розрахованого на основі показника економічного потенціалу), вдалося отримати агровиробнику в поточних умовах господарювання. Якщо економічна результативність підприємства в даному виробничому циклі або звітному періоді дорівнює одиниці, то це означає, що підприємство або господарство змогло наростити свою потужність до рівня потенціалу і отримати весь потенціальний прибуток, який можна було згенерувати.

Запропонований комплекс аналітичних процедур, що включає розрахунок показників економічного потенціалу, економічної потужності і економічної результативності та, відповідно, їх аналіз, дає змогу управлінцям оцінити діяльність підприємства у новому вимірі та зорієнтуватися у причинах звуження каналів отримання запланованого та потенціального прибутку.

3 метою підтримки запровадження, використання запропонованого аналітичного комплексу та прийняття рішень щодо подальших тактичних i стратегічних кроків пропонуємо використовувати спеціалізовані документальні форми.

Такі форми були розроблені у відповідності до потреб обліковців та управлінців для ефективного фрормування коректних досліджуваних показників:

- Форма 1-Епл, відомість (експериментальна): заповнюється у відповідності до обраних компонент економічного потенціалу та обраного періоду дослідження; у разі щорічного складання формуються квартальні дані, а в кінці року - річні; розрахунковий час заповнення фрорми вручну 20 хв.;

- Форма 1-Епт, відомість (експериментальна): заповнюється у відповідності до обраного методу розрахунку економічної потужності та обраного періоду дослідження; у разі щорічного складання формуються квартальні дані, а в кінці року - річні; розрахунковий час заповнення форми вручну 10 хв.;

- Форма 1-Ерез звітна: $€$ звітною фрормою управлінського обліку, заповнюється на основі розрахованих показників економічного потенціалу та економічної потужності, може заповнюватись помісячно або поквартально 3 річним підсумком; розрахунковий час заповнення форми вручну 5 хв.

У разі використання комп'ютерної форми обліку пропонуємо додати запропоновані відомості та звіт в модуль звітності, в підрозділ управлінської звітності. В такому випадку час заповнення не перевищуватиме 3 хвилин на кожний документ. Запропонована звітна форма 1-Ерез має вигляд короткої таблиці (табл. 1).

При використанні комп'ютерної форми обліку пропонуємо застосовувати інфографічну демонстрацію показників економічної результативності у вигляді графіку або діаграми з місячними, квартальними та річними показниками. 
46 • Scientific discoveries: projects, strategies and development $\bullet$ Volume 1

Таблиця 1

\begin{tabular}{|c|c|c|c|c|c|}
\hline \multicolumn{3}{|c|}{ 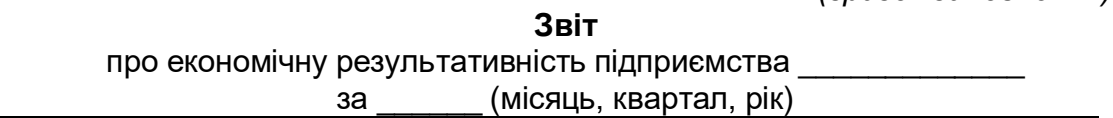 } & \multicolumn{3}{|c|}{$\begin{array}{r}\text { Форма 1-Ерез від } 2019 \\
\text { (експериментальна) } \\
\text { (зразок заповнення) }\end{array}$} \\
\hline \multirow{2}{*}{ Показник } & \multicolumn{4}{|c|}{ Період } & \multirow{2}{*}{ Рік } \\
\hline & І кв. & ІІ кв. & III кв. & IV кв. & \\
\hline Економічний потенціал підприємства & 0,33 & 0,26 & 0,20 & 0,22 & 0,42 \\
\hline Економічна потужність підприємства & 0,03 & 0,21 & 0,01 & 0,04 & 0,11 \\
\hline $\begin{array}{l}\text { Економічна результативність } \\
\text { (Коеф. співвідношення } \\
\text { економічної потужності та } \\
\text { економічного потенціалу) }\end{array}$ & 0,09 & 0,83 & 0,03 & 0,16 & 0,25 \\
\hline
\end{tabular}

Джерело: розроблено автором.

\section{Список використаних джерел:}

1. Загорецька, О. Я. (2009). Обгрунтування нормативного значення рентабельності продукції для машинобудівних підприємств. Вісник Національного університету "Львівська політехніка", 5(640), 83-90.

2. Дзюба, Т. І. (2017). Сутність і концептуальні засади формування економічної потужності в системі показників бухгалтерського обліку підприємства. Подільський вісник: сільське господарство, техніка, економіка, (27), 256-262.

3. Мороз, Ю. Ю. (2012). Формування економічного потенціалу підприємства в системі показників бухгалтерського обліку. Вісник Житомирського національного агроекологічного університету, 2(2), 314-322. Вилучено 3 http://nbuv.gov.ua/UJRN/Vzhnau_2012_2\%282\%29_35.

4. Лазаришина, І. Д. (2006). Основні теоретичні засади економічного аналізу додаткової вартості. Наукові праці Кіровоградського національного технічного університету. Економічні науки: зб. наук. пр., (10), Ч. 2., 135-139. 


\title{
ФОРМУВАННЯ АНТИКРИЗОВОЇ СТРАТЕГІЇ НА ОСНОВІ АНТИКРИЗОВОГО ПОТЕНЦІАЛУ ПІДПРИЕМСТВА
}

\author{
Шатайло Ольга Анатоліївна \\ Хмельницький національний університет \\ Науковий керівник: Тюріна Н. М. \\ д-р. екон. наук, професор \\ Хмельницький національний університет \\ УКРÄ̈HA
}

За сучасних ринкових умов будь-яке підприємство повинне бути готовим до змін, які застосовуються та адаптуються відповідно до умов зовнішнього та внутрішнього середовища. Вони можуть бути пов'язаними із різними фракторами впливу, серед яких одним із основних вважається виникнення кризових явищ.

Результати успішного подолання різних видів криз залежать від ефеективності антикризового управління, що потребує залучення потенційних можливостей і ресурсів, закумульованих та сформованих в антикризовому потенціалі підприємства.

Його формування відбувається шляхом трансформації, оптимізації та адаптації наявного потенціалу [1]. Адже в кризових умовах підприємство змушене використовувати саме наявні, а не нові, потенційні можливості для подолання кризових явищ.

Те саме відбуватиметься і 3 стратегією підприємства. її потрібно адаптувати та спрямувати на подолання конкретної кризи.

Для досягнення цієї мети нам потрібно спершу проаналізувати усі складові антикризового потенціалу. Вони є наступними: фінансова, виробнича, організаційно-управлінська, технологічна, ресурсна, інноваційна, інвестиційна, інформаційна, маркетингова, науково-технічна та інші.

Паралельно із оцінкою можливостей підприємства, посилено має бути задіяна інформаційна та маркетингова складова в наслідок чого має бути зібрана та проаналізована уся необхідна інформація, що дозволить прогнозувати ситуацію на ринку хоча б в короткостроковому періоді.

Після того, як усі необхідні дані будуть зібрані та проаналізовані, ми можемо сформувати ряд антикризових дій із складовими антикризового потенціалу, які уособлюють у собі антикризову стратегію.

Ми пропонуємо один із варіантів формування антикризової стратегії (табл. 1).

Таблиця 1

Формування антикризової стратегії на основі складових антикризового потенціалу

\begin{tabular}{|l|l|}
\hline $\begin{array}{l}\text { Складова антикризового } \\
\text { потенціалу }\end{array}$ & Базові дії, які відповідають антикризовій стратегії \\
\hline Фінансова & Використання резервного фонду. \\
\hline Інноваційна & Застосовується за умов технологічної кризи. \\
\hline Трудова & $\begin{array}{l}\text { Скорочення трудових ресурсів відповідно до зменшення обсягів } \\
\text { виробництва. }\end{array}$ \\
\hline
\end{tabular}


Продовення табл. 1

\begin{tabular}{|l|l|}
\hline \multirow{5}{*}{$\begin{array}{l}\text { Організаційно- } \\
\text { управлінська }\end{array}$} & $\begin{array}{l}\text { Підтримка рівня корпоративної культури, соціально- } \\
\text { психологічного клімату на підприємстві та у його підрозділах. }\end{array}$ \\
\hline Оптимізація виробничих процесів. \\
Пошукальтернативних рішень для відновлення потужності. \\
Максимальна координація та злагоджена робота управлінських \\
підрозділів, підвищення професіоналізму керівників, фахівців та \\
технічнихвиконавців.
\end{tabular}

Сформовано автором на основі [1-2].

Отже, формування антикризової стратегії дійсно залежить від антикризового потенціалу підприємства і відбувається шляхом трансформації наявного потенціалу, оптимізації його складових і адаптації до конкретного виду кризи.

\section{Список використаних джерел:}

1. Тюріна, Н. М. \& Шатайло, О.А.(2018). Антикризовий потенціал: сутнісні характеристики та структуризація. Бізнесінформ, (5), 434-439.

2. Шатайло, О. А. (2018). Сутність антикризового потенціалу підприємства. Актуальні питання сучасної науки (частина II): матеріали IV міжнародної науково-практичної конфреренції, 29-30 квітня 2018 року. Київ, Україна. 


\title{
ШЛЯХИ ПІДВИЩЕННЯ КОНКУРЕНТОСПРОМОЖНОСТІ ПІДПРИЄМСТВА НА ПРИКЛАДІ КАВ'ЯРНІ «РАКЕТА КОФЕ»
}

\author{
Сітало Неля Григорівна \\ Студентка кафедри менеджменту та маркетингу \\ Одеська національна академія зв'язку ім. О.С. Попова \\ Науковий керівник: Буряк Валерій Григорович \\ старший викладач філії кафедри менеджменту та маркетингу \\ Одеська національна академія зв'язку ім. О.С. Попова \\ УKPÄ̈HA
}

Постановка проблеми. В умовах посилення конкурентної боротьби для кожного підприємства на перший план виходить завдання збереження i підвищення власної конкурентоспроможності. Управління конкурентоспроможністю підприємства харчування отримало особливу значущість з огляду на появу нових ідей для розвитку ресторанного бізнесу, нових запитів споживачів, розвитку сучасних інформаційних технологій.

Сучасний ринок громадського харчування $є$ досить розвиненим, існує сформована мережа конкурентів, що мають аналогічні послуги з цінових та якісних параметрів. В основному, дана галузь складається з безлічі середніх i великих підприємств, кожне з яких відіграє вирішальну роль у загальному обсязі продажів галузі.

Головне завдання керівників даних підприємств полягає в утриманні і нарощуванні конкурентних переваг. Адже, конкурентна ситуація на ринку зростає з кожним днем все більше і більше, тому у підприємства існує потреба в систематичному відстеженні конкурентних змін на ринку. Тільки в таких умовах підприємство може дати правильну оцінку можливостям конкурентів і власним можливостям, а також виробити найбільш підходящу маркетингову стратегію, постійно спрямовану на створення або підтримання власної конкурентної переваги.

Способи підвищення конкурентоспроможності підприємств в цих умовах багато в чому визначає підвищення якості продукції, зниження цін на послуги та товари, впровадження інновацій і нових технологій, пошук нових можливостей.

Таким чином, вивчення споживачів, конкурентів, умов конкуренції дозволить підприємству визначити його переваги і недоліки перед конкурентами, виробити успішні конкурентні стратегії та підтримати конкурентні переваги. Підприємство повинно знати, якою мірою воно конкурентоспроможне по відношенню до інших суб'єктів даного ринку, так як висока ступінь конкурентоспроможності $\epsilon$ гарантом отримання високих економічних показників у ринкових умовах.

Аналіз досліджень та публікацій. Багато вчених і практиків внесли вагомий внесок у дослідження теоретичних питань та основ становлення системи конкурентоспроможності підприємств, ці дані базуються на роботах 
М. Портера, С. Брауна, І. Кірцнера, А. Томпсона, І. Ансофффа, А. Стрікленда, У. Демінга та ін.

В даний час вже придбали досить широку популярність праці: Б. Губського, С. Мочерного, Ф. Павленка, С. Бурланкова, В. Баутіна, Г. Азоєва, А. Бикова, Т. Бурменко, В. Горєва, Н. Новікової, Р. Фатхутдінова, А. Градова, А. Кротова, Л. Родіонова, В. Подсолонка, В.Сизоненка та ін., в яких висвітлено проблеми конкурентоспроможності підприємств. Водночас має місце низка проблем з оцінки та підвищення конкурентоспроможності підприємств ресторанного бізнесу як у практиці та теорії, так і в методології, які поки слабо вивчені.

Отже, проблеми з організації роботи українських підприємств у сфері харчування і підвищення їх конкурентоспроможності ще не достатньо вирішені і вимагають підвищеної уваги.

Мета статті полягає у дослідженні системи підвищення конкурентоспроможності підприємства на прикладі кав'ярні «Ракета кофее. Автори визначають корисність та актуальність власної статті; мета випливає 3 постановки загальної проблеми і огляду раніше виконаних досліджень.

Виклад основного матеріалу. Конкурентоспроможність являється складним і різнобічним поняттям, що містить складові діяльності підприємства, а саме товар або послуги підприємства та їх основні характеристики (якість, технологію виробництва, актуальність, доступність). Сутність конкурентоспроможності не має на увазі загальноприйнятого, кількісного визначення, а об'єкт аналізу конкурентоспроможності, це не тільки товар або послуга, а діяльність організації в цілому.

Конкуренція відноситься до економічних категорій, сутність яких не має однозначного тлумачення. По мірі становлення і розвитку економічної думки в змісті поняття «конкуренція» відбивалися різні аспекти. Можна виділити кілька теоретичних підходів до розуміння економічного змісту поняття «конкуренція».

Спочатку слово «конкуренція» увійшло в економічну теорію з побутової мови і протягом тривалого часу позначало тільки незалежне суперництво двох чи більше осіб. 3 цього випливає, що конкуренція являється багаторівневим явищем, яке можна виявити на різних рівнях: макроекономічному, мезоекономічному і мікроекономічному. Вона може розглядатися в різних аспектах, в тому числі: як спосіб координації господарської діяльності, як механізм взаємодії агентів ринку, як спосіб досягнення економічних цілей, як спосіб завоювання конкурентних переваг [3].

В умовах сьогодення у сучасній економіці широко застосовується категорія «конкурентоспроможність». Це обумовлюється різноманітністю смислів, які вкладаються в даний термін, і його інтерпретацію. Дана обставина пояснює відсутність уніфрікованого розуміння категорії «конкурентоспроможність»: семантичне і сутнісне наповнення категорії варіюється в залежності від цілей і об'єкту дослідження [4].

В ході аналізу наукових публікацій з проблем конкурентоспроможності було виявлено, що кожен автор дає своє визначення конкурентоспроможності в залежності від цілей і завдань свого дослідження, аспектів конкретного об'єкта, а також ґрунтуючись на вимогах суб'єктів ринкових відносин. Наведемо деякі визначення поняття «конкурентоспроможність».

Конкурентоспроможність підприємства - це здатність підприємства створювати таку перевагу над конкурентами, яка дозволяє досягти поставлених цілей [2]. 
Конкурентоспроможність - це обумовлене економічними, соціальними, політичними факторами становище товаровиробника на внутрішньому i зовнішньому ринках, що відображається через показники, які адекватно характеризують такий стан і його динаміку [1].
Аналіз наведених
визначень
економічної
категорії «конкурентоспроможність» дозволяє сформулювати авторське визначення, а саме, конкурентоспроможність - це здатність підприємства функціонувати в динамічному конкурентному середовищі, при цьому реалізувати конкурентоздатні товари чи послуги, при цьому залучати і зберігати споживачів своєї продукції, підвищувати конкурентні переваги і збільшувати свою частку на ринку.

Перш ніж запропонувати основні шляхи підвищення конкурентоспроможності кав'ярні «Ракета кофе» необхідно провести оцінку її конкурентоспроможності. «Ракета кофе» входить до складу компанії «Rocket coffee Group». Компанія «Rocket coffee Group» створює різнобічну, концептуальну мережу закладів для відпочинку. Це заклад громадського харчування 3 не дуже широким асортиментом страв та 3 широким асортиментом гарячих безалкогольних напоїв.

ТОВ «Ракета кофе» задовольняє попит споживачів у послугах громадського харчування, і одержує прибуток, за рахунок різних видів діяльності. Основними видами діяльності кав'ярні $є$ : надання послуг громадського харчування, надання послуг з виготовлення кулінарної продукції та кондитерських виробів, надання послуг з організації споживання та обслуговування, надання послуг з організації дозвілля.

Маркетингова діяльність в кав'ярні «Ракета кофе» здійснюється безпосередньо директором - саме він вирішує, як, коли, які і яким чином будуть використані інструменти маркетингу, спрямовані на підвищення привабливості та конкурентоспроможності підприємства. В окремих випадках пропозиції можуть бути запропоновані адміністратором, але рішення про прийняття та впровадження будь-якого заходу завжди стоїть за керівником «Ракета кофе».

Кав'ярня «Ракета кофе» використовує наступні методи просування: зовнішня реклама - вивіска, покажчики, інформаційні таблички, Інтернетреклама, замовні та незамовні статті, новини в друкованих та інтернет-ЗМІ, новинних стрічках, POS-матеріали - фірмові візитки, фрлаєра, буклети, що нагадують про кав'ярню, внутрішні акції та свята, компліменти і подарунки, програми лояльності та дисконтні програми.

Керівництво фрірми сприймає різні ринкові можливості, оцінює сильні сторони свого потенціалу, які кав'ярня має намір задіяти, підтримуючи традиції в області стратегічних рішень існуючих на фрірмі.

Аналіз конкурентоспроможності кав'ярні «Ракета кофе» було проведено в кілька етапів: в першу чергу було оцінено аналіз зовнішнього конкурентного середовища, а потім проведена оцінка внутрішнього конкурентного потенціалу кав'ярні.

Для оцінки зовнішнього конкурентного середовища було використано с найбільш поширений метод - модель п'яти сил конкуренції М Портера. Аналіз конкурентного середовища за моделлю п'яти сил конкуренції М. Портера представлений в процентному співвідношенні на рис. 1. 


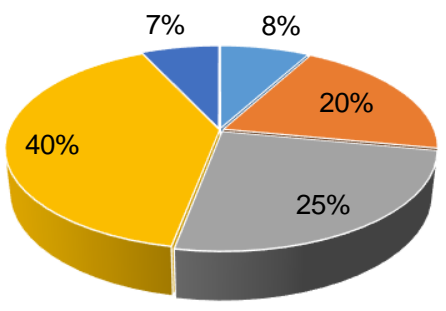

- Вплив постачальників

- Вплив споживачів

- Загроза появи нових гравців

Загроза внутрішньо-галузевої конкуренції

- Загроза товаро-замінників

\section{Рис. 1. Аналіз конкурентного середовища за моделлю п'яти сил конкуренції М. Портера}

Проведений аналіз показав що:

1. Загроза з боку товарів-замінників - середня. Кав'ярня не володіє унікальною пропозицією на ринку, існує багато аналогів, пропонованих ним товарів і послуг. Основні зусилля кав'ярня повинна зосередити на побудові високого рівня знання товару і на побудові обізнаності про особливості товару.

2. Досить висока загроза внутрішньогалузевої конкуренції. Ринок організації $\epsilon$ високо конкурентним і перспективним. Відсутня можливість повного порівняння товарів різних кав'ярень. $€$ обмеження в підвищенні цін. Для збереження конкурентоспроможності необхідно постійно проводити моніторинг пропозицій конкурентів.

3. Ризик входу нових гравців високий. Нові компанії організації постійно з'являються.

Аналізуючи такий фрактор, як «потенційні конкуренти», ми можемо сказати, що, незважаючи на відсутність впевнених позицій даних об'єктів на ринку послуг громадського харчування, їх поява все ж вносить деяку нервозність для вже існуючих фірм через ущільнення ринку харчування в місті Києві.

Конкуренція з боку товарів-замінників виникає тоді, коли продукція, пропонована підприємством, має подібні характеристики з продукцією, що виробляється іншими підприємствами з цієї або іншої галузі.

Фактор «постачальники» також впливає на конкурентоспроможність кав'ярні. Кав'ярня «Ракета кофе» має дуже багато постачальників. Загроза «постачальників» кав'ярні може бути пов'язана 3 порушенням термінів поставок, низькою якістю сировини та обладнання, підвищенням цін, інших порушень договірних відносин.

Споживачі впливають на кав'ярню через вплив на ціни споживаних товарів і послуг, вимогам до їх якості та післяпродажне обслуговування, оскільки попит не такий високий як пропозиція. Споживачі послуги кав'ярні, можуть являти собою також загрозу, пов'язану з частковою втратою кав'ярнею клієнтської бази, перерозподілом клієнтів у зв'язку з кількісним і якісним зростанням підприємств-конкурентів.

Таким чином, найбільший вплив на діяльність кав'ярні «Ракета кофе» та його конкурентоспроможність надають споживачі та галузеві конкуренти. Виходячи з аналізу внутрішньої і зовнішньої конкурентоспроможності кав'ярні 
«Ракета кофе», можна зробити висновки, що існує висока загроза внутрішньогалузевої конкуренції. Ринок організації $€$ високо конкурентним і перспективним. Відсутня можливість повного порівняння товарів різних організацій. $€$ обмеження в підвищенні цін. Для збереження конкурентоспроможності необхідно постійно проводити моніторинг пропозицій конкурентів.

Результати порівняльного аналізу найбільш прямого конкурентного оточення досліджуваного об'єкта (кав'ярні «Ракета кофе»), критеріями якого стали місце розташування, спеціалізація і рівень обслуговування, показав, що основними конкурентами кав'ярні «Ракета кофе» є: кав'ярня «We.Cafe», кав'ярня «Cup \& Cake», кав'ярня «Friends Cafe», кав'ярня «Nikki», кав'ярня «Kredens cafe», кав'ярня «l like coffee», кав'ярня «Royal Bakery», кав'ярня «Empire coffee», кав'ярня «Good stay». Особливостями кав'ярень-конкурентів є: наявність своєї фірмової кави, надання додаткових послуг (жива музика, бізнес-ланчі і т. д.), стиль кав'ярні (український, французький, чеський, американський і т.д.).

Виходячи з оцінки конкурентоспроможності кав'ярні видно, що «Friends Cafe» $\epsilon$ одним з головних конкурентом для «Ракета кофе», так як працює в даному бізнесі досить тривалий час, $є$ відомим, впізнаваним закладом в місті, зі зручним місцем розташування та великим асортиментом меню.

Виходячи 3 аналізу внутрішньої і зовнішньої конкурентоспроможності кав'ярні «Ракета кофе», можна зробити висновки, що існує висока загроза внутрішньогалузевої конкуренції. Ринок організації $€$ високо конкурентним i перспективним. Відсутня можливість повного порівняння товарів різних організацій. $€$ обмеження в підвищенні цін. Для збереження конкурентоспроможності необхідно постійно проводити моніторинг пропозицій конкурентів. Низьким конкурентним чинникам кав'ярні «Ракета кофе» $\epsilon$ обмежена кількість послуг. У кав'ярні немає доставки готової продукції додому і за рахунок цього, кав'ярня втрачає велику кількість клієнтів. Ще однією негативною стороною «Ракета кофе» $\epsilon$ неефективна рекламна діяльність.

Аналіз особливостей стану кав'ярні та загальновідомі підходи до підвищення конкурентоспроможності, надають можливість сформулювати принципи методологічного підходу до підвищенню конкурентоспроможності: забезпечення конкурентоспроможності підприємства включає забезпечення конкурентоспроможності товарів і послуг, визначення критеріїв конкурентоспроможності підприємства повинно виходити 3 горизонту планування i системи менеджменту підприємства, показником конкурентоспроможності підприємства на оперативному рівні $є$ сукупний коефріцієнт конкурентоспроможності товарів і послуг, тактичний рівень конкурентоспроможності підприємства забезпечується за рахунок фрінансовогосподарського стану та подано комплексним коефіцієнтом, стратегічний рівень конкурентоспроможності підприємства представлений інвестиційною привабливістю, яка обумовлена зростанням вартості бізнесу.

Виділимо наступні шляхи підвищення конкурентоспроможності кав'ярні «Ракета кофе»: безперервне використання нововведень, пошук найбільш досконалих пропозицій, надання послуг, що задовольняє вимоги вітчизняних i світових стандартів якості, використання сировини і матеріалів найвищої якості, навчання та перепідготовка персоналу, поліпшення умов праці та 
мотивування працівників, проведення маркетингових досліджень ринку, аналіз діяльності конкурентів, використання найбільш ефективних каналів реклами.

Використовуючи дані шляхи, кав'ярня зможе підвищити свою конкурентоспроможність, і разом з тим зміцнити свою фінансову стійкість. В цілях підвищення конкурентоспроможності підприємства необхідно використовувати комплекс тактичних і стратегічних способів і інструментів служби маркетингу.

Висновки та пропозиції. На сьогоднішній день нереально домогтися стабільного успіху в бізнес-сфері без підвищення конкурентоспроможності підприємства. При рівних умови важливою роллю є маркетингова складова підприємства. Маркетинг дозволяє виявити найбільш важливі потреби клієнта, проводить калькуляцію змін споживчих переваг, оцінює перспективність сегментів ринку, розробляє стратегію для підвищення конкурентоспроможності.

Отже, можна зробити висновок, що конкурентоспроможність підприємства - це можливість ефективної діяльності в галузі господарства та прибуткової практичної реалізації даної діяльності в конкурентному середовищі ринку.

Провівши оцінку конкурентоспроможності кав'ярні «Ракета кофе» було визначено необхідність розроблення заходів, спрямованих на збільшення конкурентоспроможності кав'ярні, які в першу чергу зможуть мінімізувати дію її слабких сторін. Для утримання конкурентних позицій на ринку доцільний постійний контроль якості виготовлення смачної та ароматної кави. 3 цією метою кав'ярні необхідний ретельний відбір постачальників, що надають якісну сировину, закріплену відповідними сертифікатами якості продукції. Вплив постачальників на підприємство посилюється, якщо їх продукти сильно диференційовані або унікальні. Як пропозиція, розглядається варіанти розширення послуг кав'ярні, а так само створення спеціальних пропозицій, наприклад доставка в офіс чи додому, для залучення нової групи клієнтів. Необхідно приділити увагу розвитку та вдосконаленню рекламної діяльності кав'ярні.

Таким чином, підвищення конкурентоспроможності підприємства досягається шляхом орієнтації підприємства на споживчу сферу, підвищення якості продукції, ефективну реалізацію товарів і послуг. Завдяки цьому збільшиться показник конкурентоспроможності підприємства, його вміння максимально використовувати свій трудовий, науково-технічний, виробничий і фінансовий потенціал.

\section{Список використаних джерел:}

1. Кравченко, О. В. (2014). Проблемы управления конкурентоспособностью предприятия. Саратов: Поволж. межрегион. учеб. центр.

2. Лупак, Р. Л. \& Васильців, Т. Г. (2016). Конкурентоспроможність підприємства. Львів: Видавництво ЛКА.

3. Мокроносов, А. Г. \& Маврина, И. Н. (2014). Конкуренция и конкурентоспособность: учебное пособие. Екатеринбург: Изд-во Урал ун-та.

4. П'ятницька, Г. Т., П'ятницька, Н. О., Шумська, С. С., Федорченко, Н. В., Гелич, А. О. \& П'ятницький, Д. В. (2017). Управління конкурентоспроможністю підприємств. Київ: Видавничий дім «Кондор». 


\section{SECTION II. AGRICULTURAL SCIENCES}

\section{ВИРОЩУВАННЯ РЕМОНТНИХ ТЕЛИЦЬ МЯСНОГО КОМОЛОГО СИМЕНТАЛУ ХУДОБИ НА ПІДСИСІ В УМОВАХ ПЕРЕДГІРСЬКОЇ ЗОНИ КАРПАТСЬКОГО РЕГІОНУ БУКОВИНИ}

НАУКОВО-ДОСЛІДНА ГРУПА:

Калинка Андрій Казимирович

канд. с.- г. наук, старший науковий співробітник Буковинська державна сільськогосподарська дослідна станція НАAH

Лесик Оксана Богданівна

канд. с.- г. наук, старший науковий співробітник Буковинська державна сільськогосподарська дослідна станція НАAН

Казьмірук Лариса Василівна канд. с.- г. наук, доцент Вінницький національний аграрний університет УКРАÏHA

В умовах економічно - фінансової кризи в нашій державі необхідно збільшити виробництво дешевої яловичини з покращеною її якістю на основі розробки різних рецептів раціонів та їх оптимізації для повноцінної годівлі жуйних у підсисному періоді, що є найбільш актуальним в умовах Карпатського регіону України [5-7].

Тому розробка у даний час теоретичних і практичних аспектів різних рецептів раціонів та типів годівлі для підсосних ремонтних телиць м'ясного комолого сименталу худоби для забезпечення високого генетичного потенціалу росту продуктивності в умовах підгірської зони регіону Буковини [34; 8-9].

Оскільки запропоновані нові дослідження в минулому не вивчалися в м'ясному скотарстві, що і $є$ досягненням наших даних досліджень в умовах Буковини. 3 цього приводу на високому рівні і було вивчено енергію росту симентальських комолих телиць народжених в зимові місяці (січень, лютий, березень) з подальшим максимальним використанням культурних пасовищ в умовах передгірської зони Чернівецької області. Цінним дуже є і важливим питанням досліджень з розроблення нового рецепту раціону ремонтним телицям в підсисному періоді взимку та на культурних пасовищах, який буде апробовано в господарствах різних форм власності регіону Буковини.

За мету наукових досліджень взяли вивчити продуктивність телиць нової популяції сименталів худоби, які народилися у зимоваі місяці з використанням підсисного методу вирощування з максимально використанням культурних пасовищ в умовах передгірського регіону Буковини.

Для цього провели науково-господарський дослід у діючому племінному заводі ДП ДГ «Чернівецьке» Герцаївського району Чернівецької області на 
телицях - м'ясного комолого сименталу худоби нової генерації з відбором 3 групи тварин в кожній по 10 голів з початковою живою масою 27,5 - 28,3 кг, згідно розробленої такої схеми досліджень: телиці 1-дослідної групи народжені у січні місяці, II-дослідна група ровесниці народжені у лютому місяці та аналоги телиці III-дослідної групи народжені у березні місяці. Ровесникам телицям IIIдослідної групи уводили додатково вітамін А два рази на місяць внутрімишечно.

Умови утримання для всіх тварин були однаковими. Дослідження на ремонтних телицях проводили в стійловому періоді та влітку на культурних пасовищах за технологією м'ясного скотарства [2-14]. В дослідженнях були використані методичні рекомендації з уніфікації досліджень з годівлі м'ясної худоби $[1 ; 10-11 ; 13]$.

При використанні власних кормів згідно розробленого рецепту раціону було отримано такі зміни в живій масі та в енергії росту ремонтних телиць м'ясного комолого сименталу худоби за весь період досліду наведені у (табл. 1).

Таблиця 1

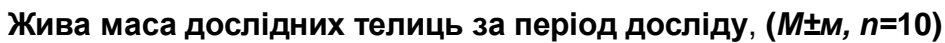

\begin{tabular}{|c|c|c|c|}
\hline \multirow{2}{*}{ Показник } & \multicolumn{3}{|c|}{ Групи тварин } \\
\hline & Дослідна-І & Дослідна-ІІ & Дослідна-III \\
\hline Кількість тварин, гол. & 8 & 8 & 8 \\
\hline $\begin{array}{l}\text { Жива маса, кг: } \\
\text { на початок досліду } \\
\text { перед виходом на пасовище }\end{array}$ & $\begin{array}{c}27,5 \pm 1,7 \\
127,0 \pm 1,2 \\
\end{array}$ & $\begin{array}{l}28,3 \pm 1,3 \\
87,3 \pm 1,7 \\
\end{array}$ & $\begin{array}{l}28,2 \pm 1,4 \\
75,4 \pm 1,5\end{array}$ \\
\hline $\begin{array}{l}\text { Приріст: } \\
\text { загальний, кг } \\
\text { середньодобовий, г }\end{array}$ & $\begin{array}{c}100,0 \pm 1,3 \\
961,5 \pm 0,065\end{array}$ & $\begin{array}{c}59,0 \pm 1,9 \\
808,2 \pm 0,85\end{array}$ & $\begin{array}{c}47,2 \pm 1,5 \\
858,2 \pm 0,35\end{array}$ \\
\hline $\begin{array}{l}\text { Жива маса, кг: } \\
\text { на кінець літнього періоду }\end{array}$ & $215,9 \pm 2,1$ & $165,7 \pm 1,9$ & $150,1 \pm 1,7$ \\
\hline $\begin{array}{l}\text { Приріст: } \\
\text { загальний, кг } \\
\text { середньодобовий, г }\end{array}$ & $\begin{array}{c}88,9 \pm 1,2 \\
728,7 \pm 0,025\end{array}$ & $\begin{array}{l}78,4 \pm 1,6 \\
642,6 \pm 0,045\end{array}$ & $\begin{array}{l}74,6 \pm 1,9 \\
666,1 \pm 0,085\end{array}$ \\
\hline \multicolumn{4}{|l|}{ Критерій вірогідності, $P$} \\
\hline $\begin{array}{l}\text { Жива маса, кг: } \\
\text { на кінець звітного періоду }\end{array}$ & $233,7 \pm 1,9$ & $183,2 \pm 2,4$ & $159,2 \pm 2,1$ \\
\hline $\begin{array}{l}\text { Приріст: } \\
\text { загальний, кг } \\
\text { середньодобовий, г }\end{array}$ & $\begin{array}{c}206,2 \pm 1,7 \\
916,4 \pm 0,075\end{array}$ & $\begin{array}{r}161,9 \pm 1,9 \\
801,5 \pm 0,095\end{array}$ & $\begin{aligned} 131,0 \pm 1,3 \\
735,9 \pm 0,067\end{aligned}$ \\
\hline $\begin{array}{l}\text { Витрати корму на } 1 \text { кг } \\
\text { приросту, к. од. }\end{array}$ & 5,7 & 7,3 & 9,0 \\
\hline
\end{tabular}

За результатами досліджень встановлено, що протягом 104 днів стійлового зимового періоду досліду телиці І-дослідної групи, які народилися в січні місяці у яких добові прирости становили - 961,5г, що на 153,3 г $(18,9 \%)$ при $(P<0,001)$ більше від ровесників дослідної - II групи, які народилися в лютому місяці. Краща оплата корму продукцією була у січневих телиць і становила 5,7 корм. од., що на 3,3 к. од., $(5,7 \%)$ менше від ровесників - аналогів березневих ровесниць.

В досліді березневі телиці мали добові прирости - 858,2г, що на 103,3г менше від ровесниць І-дослідної групи. За 225 днів досліду при вирощуванні 
телиць І-дослідної групи взимку та при випасанні на культурних пасовищах, енергія росту збереглася така сама, як в стійловому періоді досліду i становила - 916,4г, що на - 180,5г (24,5\%) більше за нащадків аналогів третьої групи.

В кінці досліду провели дослідження на біохімічні показники крові дослідних телиць (табл. 2).

Таблиця 2

Біохімічні показники крові дослідних телиць

\begin{tabular}{|l|c|c|c|}
\hline \multirow{2}{*}{\multicolumn{1}{|c|}{ Показник }} & \multicolumn{3}{|c|}{ Дослідні групи } \\
\cline { 2 - 4 } & Дослідна-І & Дослідна-ІІ & Дослідна-ІІІ \\
\hline Холестирин, ммоль/л. & $3,07 \pm 0,4$ & $3,8 \pm 0,2$ & $3,2 \pm 0,4$ \\
\hline Глюкоза, ммоль/л. & $3,5 \pm 0,5$ & $3,9 \pm 0,005$ & $3,5 \pm 0,5$ \\
\hline Білок г/л & $72,6 \pm 5,8$ & $89,3 \pm 3,9$ & $70 \pm 7,6$ \\
\hline АСТ, од/л. & $63,3 \pm 2,9$ & $113,3 \pm 3,6$ & $58,3 \pm 2,7$ \\
\hline Г-ГПТ, од/л. & $23,3 \pm 3,4$ & $29,6 \pm 1,4$ & $20,0 \pm 0,6$ \\
\hline КФК, од/л. & $214,6 \pm 54,3$ & $362,2 \pm 36,2$ & $174,3 \pm 11,6$ \\
\hline ЛДГ, од/л. & $1398 \pm 177,5$ & $1085 \pm 467,6$ & $1405 \pm 69,5$ \\
\hline Амілаза, од/л. & $185,1 \pm 58,2$ & $342,6 \pm 116,3$ & $120,2 \pm 46,5$ \\
\hline Тригліцириди, ммоль/л. & $0,11 \pm 0,07$ & $0,09 \pm 0,07$ & $0,13 \pm 0,06$ \\
\hline Мочевина, ммоль/л. & $27,3 \pm 12,1$ & $57,3 \pm 2,0$ & $15,3 \pm 11,3$ \\
\hline Щолочна фросфатаза, од/л & $82,3 \pm 67,2$ & & $129 \pm 39,4$ \\
\hline АЛТ, од/л & $16,6 \pm 0,6$ & $24,3 \pm 3,6$ & $4,6 \pm 3,7$ \\
\hline Креатинін, ммоль/л. & $156,2 \pm 8,4$ & $154,3 \pm 17,7$ & $140,1 \pm 20,1$ \\
\hline Білорубін, ммоль/л. & $34,3 \pm 26,0$ & $11,9 \pm 0,9$ & $18,8 \pm 6,1$ \\
\hline
\end{tabular}

Встановлено, що загальний білок крові до годівлі був підвищений у лютневих телиць $(89,0)$ по відношенню до ровесниць 1-дослідної групи. В результаті проведених досліджень, встановлено, що рівень глюкози крові у тварин другої дослідної групи до годівлі був підвищений і суттєво не відрізнявся від двох дослідних груп. Холестерин крові січневих телиць досягав 3,07 ммоль/л і мав тенденцію до підвищення в порівнянні з 11-дослідною групою. Відмічалось зниження концентрації тригліцеридів у другій групі і досягав 0,09 ммоль/л, а також у всіх групах. Рівень креатиніну крові у всіх групах був на рівні і досягав (140,1 - 154,32 ммоль/л) і дещо був підвищений в телицях, яким уводили вітамін А.

Концентрація білорубіну в сироватці крові січневих телиць дорівнювала 34,3 ммоль/л, в той час, як в 11-, 111-дослідній групі даний показник був знижений відповідно до 22,4 і 15,5 ммоль/л. Важливим фактором печінки $є$ визначення активності основних фрерментів оргганоспецифічних в сироватці крові дослідних телиць. Так активність алані нової амінотрансферази ( АЛТ) в 1-дослідній до годівлі складала 185,1 од/л. В той же час, як в 111-дослідній групі тварин даний показник був значно підвищеним і склав 120,0 од/л. $(\mathrm{P}<0,05)$. Активність гамма - глюталатпептидази (Г-ГТП) в 1-дослідній групі до годівлі була 23,0 од/л., що більше на 3,0од./л від 111-дослідної групи.

Дослідженнями доведено, що кращі економічні показники отримано в 1дослідній групі, в яких затрати кормів на 1 ц приросту живої маси склали 5,7 ц. 
к. од., собівартість приросту живої маси 1 голови за період вирощування дорівнювала 1050 грн. Чистий дохід на 1 голову в даній групі був найбільшим i становив - 644,4грн. при рентабельності - 61,4\% в умовах зони Карпат.

Таким чином при проведенні досліджень з вирощування телиць м'ясного сименталу худоби нової генерації, які народилися в січні місяці, при цьому досягаються добові прирости - 916,4г, що на 180,5г (24,5\%) більше від ровесниць березневих із рентабельність - 39,0\%, що забезпечує розроблену інтенсивну технологію вирощування жуйних економічно перспективною та сприяє на майбутнє більш ранньому господарському використанню телиць в умовах передгірної зони Буковини.

\section{Список використаних джерел:}

1. Бабич, А. О. (1998). Методика проведення дослідів з кормовиробниитва і годівлі тварин. К.: Аграрна наука.

2. Калашников, А. П., Клейменов, А. И. \& Беканов В. Н. (1985). Нормы и рационы кормления С.-х. животных. М.: Агропромиздат.

3. Калинка, А. К. \& Шпак, Л. В. (2008). Интенсивное выращивание молодняка крупного рогатого скота в условиях предгорья Карпат. Зоотехния, (2), 15-19.

4. Калинка, А. К. (2009). Інтенсивність росту м'ясних сименталів в умовах передгір'я Карпат. Тваринництво України, (6), 17-20.

5. Калинка, А. К. (2003). Інтенсивне вирощування ремонтних бугайців симентальської м'ясної породи американської селекції в умовах передгір'я Карпат. Тваринництво України, (11), 1920.

6. Калинка, А. К. \& Повозніков, М. Г. (2004). Відгодівельні якості молодняку м'ясної худоби на різних типах годівлі в передгір'ї Карпат. Зб. наукових праць Подільського держ.-тех. Університету, (12), 159-162.

7. Калинка, А. К. (2002). Вплив раціонів на відгодівельні якості м'ясного молодняку. Тваринництво України, (8), 26-27.

8. Комплексна програма фундаментальних досліджень щодо наукового забезпечення розвитку галузей агропромислового комплексу України на 2001-2005 рр. (2001). Київ.

9. Криворучко, Ю. І. (2002). М'ясна продуктивність телиць різних генотипів створюваної української симентальської м'ясної породи. Тваринництво України, (6), 23-24.

10. Богданов Г. О., Славов В. П. \& Ібатулін І. І. (2002). Методичні рекомендації уніфрікації досліджень по годівлі м'ясної худоби. Київ.

11. Ойвін, И. А. (1960). Статистическая обробка результатов єкспериментальних исследований. Патологическая физиология и єкспериментальные исследования, (4), 7679.

12. Овсянников, А. И. (1976). Основы опытного дела в животноводстве. М.: Колос.

13. Козирь, В. С., Свеженцов, А. И. \& Качалова, Е. Я. (2002). Практические методики исследований в животноводстве. Днепропетровск: АРТ-Прес.

14. Чигринов, Є. І., Маменко, О. М. \& Прудніков, В. Т. (1998). Методичні основи досліджень по технології м'ясного скотарства. Харків: ІТ УААН. 


\title{
НОВА ПОПУЛЯЦІЯ СТАД М'ЯСНИХ СИМЕНТАЛІВ ХУДОБИ В КАРПАТСЬКОМУ РЕГІОНІ УКРАЇНИ
}

\author{
НАУКОВО-ДОСЛІДНА ГРУПА: \\ Калинка Андрій Казимирович \\ канд. с.-г. наук., старший науковий співробітник \\ Буковинська державна сільськогосподарська дослідна станція НАAН \\ Шпак Людмила Вадимівна \\ канд. с.-г. наук., провідний науковий співробітник \\ відділення зоотехнії Президії НААН \\ Петращук Іван Миколайович \\ начальник відділу продовольства та аграрного ринку \\ Департамент АПР Чернівецької держадміністрації \\ УКРӒ̈HA
}

У даний час актуальним в умовах ринку $є$ завдання, селекційно генетичними методами створити на базі місцевих сименталів, новий м'ясний симентал з використанням кращого генофонду симентальської породи м'ясного напрямку продуктивності зарубіжної та вітчизняної селекції для отримання дешевої яловичини, що є найбільш актуальним для Карпатського регіону України [1-4].

Так вже створений буковинський зональний тип м'ясного сименталу худоби де науковці, спеціалісти тваринники і керівники базових та дочірніх господарств створили відповідно до нових господарсько - кліматичних до місцевих умов Буковини та Галичини з виведенням більш продуктивної м'ясної худоби з високою енергією росту, м'ясною продуктивністю та економічною ефективністю для даного регіону.

Загальна кількість худоби нового типу м'ясного сименталу нової генерації нараховується біля - 995 голів в Чернівецькій, в тому числі 453 голови корів м'ясного напрямку продуктивності та 165 голів корів в Івано - Франківській областях. В дослідженнях, визначили, середню жива масу корів створюваного буковинського зонального типу м'ясного сименталу худоби в племінних господарствах Чернівецької та Івано - Франківської областях (табл. 1).

Встановлено (табл. 1), що жива маса корів м'ясного комолого сименталу худоби становила 491- 569 кг, (у середньому 529 кг), а окремі рекордистки мали живу масу близько 850 кг і більше.

При створенні нового м'ясного типу сименталу худоби важливого значення приділяли питанню формуванню вікової структури живої маси стада, як одному з головних фракторів високої м'ясної продуктивності для зони Карпат.

Робота з формування м'ясного комолого сименталу худоби нової генерації вперше приводилася протягом 20 років в племінному заводі "Чернівецький " Герцаївського району Чернівецької області під методичним керівництвом науковців сектору селекції, годівлі і технології в м'ясному скотарстві колишнього Буковинського інституту АПВ НАНУ та лабораторії селекції м'ясних порід Інституту розведення і генетики тварин НАНУ на поголів'ї 226 корів ( 1999 - 2006 рр.), 160 - (2007 - 2010 рр.) і 153 корів ( 2011 -2016р.р., 151 
$60 \bullet$ Scientific discoveries: projects, strategies and development $\bullet$ Volume 1

- (2017-2019 -). У результаті завершеної селекційної - племінної роботи в Чернівецькій області в шести базових господарствах сформовано дуже ціні стада в кількості 453 корів м'ясного комолого сименталу нового типу з високою енергією росту молодняку на підсосі 900 - 1500 г на добу влітку та 800-900 г за повний цикл вирощування із забійним виходом $60-61,2 \%$ при витратах корму на 1 кг приросту $7,5-8,1$ к. од.

Таблиця 1

Середня жива маса корів м'ясного сименталу, кг

\begin{tabular}{|c|c|c|c|c|c|c|c|c|}
\hline \multirow{3}{*}{ Господарства } & \multicolumn{8}{|c|}{ Вік, років } \\
\hline & \multicolumn{2}{|c|}{3} & \multicolumn{2}{|c|}{4} & \multicolumn{2}{|c|}{5 і старше } & \multicolumn{2}{|c|}{$\begin{array}{c}\text { Середньому по } \\
\text { стаду }\end{array}$} \\
\hline & гол. & кг & гол. & кг & гол. & кг & гол. & Кг \\
\hline \multicolumn{9}{|c|}{ Чернівецька область } \\
\hline $\begin{array}{l}\text { ДП ДГ } \\
\text { „Чернівецьке” }\end{array}$ & 17 & 491 & 25 & 543 & 120 & 579 & 160 & 534 \\
\hline $\begin{array}{l}\text { ДП “ Рокитне” } \\
\text { СТОВ „Авангард” }\end{array}$ & 15 & 475 & 25 & 531 & 50 & 557 & 23 & 521 \\
\hline СВПК «Перемога» & 13 & 485 & 17 & 541 & 63 & 565 & 47 & 530 \\
\hline CIM МЗІД « Гай» & 3 & 487 & - & - & - & - & 3 & 487 \\
\hline CВ « Зоря» & 5 & 480 & 7 & 545 & 33 & 555 & 45 & 527 \\
\hline ПП «Колосок - 2» & 3 & 485 & 6 & 547 & 29 & 550 & 35 & 527 \\
\hline В середньому & & 484 & 80 & 538 & 325 & 567 & 461 & 529 \\
\hline \multicolumn{9}{|c|}{ Івано-Франківська область } \\
\hline СФГ " Поточище" & 13 & 475 & 15 & 525 & 47 & 537 & 75 & 512 \\
\hline ПАТ“ Жуківське ” & 5 & 467 & 7 & 540 & 21 & 570 & 33 & 526 \\
\hline ПП « Богдан» & 3 & 456 & 5 & 535 & 13 & 550 & 21 & 513 \\
\hline Усього & 21 & 466 & 27 & 533 & 81 & 552 & 129 & 517 \\
\hline
\end{tabular}

У дослідженнях визначено молочну продуктивність корів м'ясного комолого сименталу худоби нової популяції за лактаціями ( жива маса телят в 210 днів) в племінних базових та дочірніх господарствах Західного регіону України (табл.2).

Таблиця 2

Молочна продуктивність корів, (M $\pm \mathrm{m})$

\begin{tabular}{|c|c|c|c|c|c|c|c|c|}
\hline \multirow{3}{*}{ Лінія } & \multicolumn{6}{|c|}{ Лактації } & \multicolumn{2}{|c|}{ Усього } \\
\hline & \multicolumn{2}{|c|}{1 - лактація } & \multicolumn{2}{|c|}{11 - лактація } & \multicolumn{2}{|c|}{11 - лактація } & \multirow[b]{2}{*}{ Голів } & \multirow[b]{2}{*}{$\begin{array}{l}\text { Жива } \\
\text { маса }\end{array}$} \\
\hline & Голів & $\begin{array}{l}\text { Жива } \\
\text { маса }\end{array}$ & Голів & $\begin{array}{l}\text { Жива } \\
\text { маса }\end{array}$ & Голів & $\begin{array}{l}\text { Жива } \\
\text { маса }\end{array}$ & & \\
\hline \multicolumn{9}{|c|}{ Племзавод “ Чернівецький ” } \\
\hline Ахіллеса 369 & 13 & 191 & 24 & 205 & 58 & 211 & 95 & 202 \\
\hline Абрікота 58311 & 8 & 187 & 22 & 195 & 35 & 207 & 65 & 196 \\
\hline Сигнала 120 & 7 & 185 & - & - & - & - & 7 & 185 \\
\hline Усього & 28 & 188 & 46 & 200 & 93 & 209 & 167 & 194 \\
\hline \multicolumn{9}{|c|}{ Племзавод ДП “ Рокитне “ СТОВ “ Авангард ” } \\
\hline Ахіллеса 369 & 3 & 187 & 5 & 191 & 2 & 201 & 10 & 193 \\
\hline
\end{tabular}


Продовження табл. 2

\begin{tabular}{|c|c|c|c|c|c|c|c|c|}
\hline \multirow{3}{*}{ Лінія } & \multicolumn{6}{|c|}{ Лактації } & \multicolumn{2}{|c|}{ Усього } \\
\hline & \multicolumn{2}{|c|}{1 - лактація } & \multicolumn{2}{|c|}{11 - лактація } & \multicolumn{2}{|c|}{11 - лактація } & \multirow[b]{2}{*}{ Голів } & \multirow[b]{2}{*}{$\begin{array}{l}\text { Жива } \\
\text { маса }\end{array}$} \\
\hline & Голів & $\begin{array}{l}\text { Жива } \\
\text { маса }\end{array}$ & Голів & $\begin{array}{l}\text { Жива } \\
\text { маса }\end{array}$ & Голів & $\begin{array}{l}\text { Жива } \\
\text { маса }\end{array}$ & & \\
\hline \multicolumn{9}{|c|}{ Племзавод ДП “ Рокитне “ СТОВ “ Авангард ” } \\
\hline Абрікота 58311 & 5 & 183 & 6 & 189 & 4 & 195 & 15 & 189 \\
\hline Усього & 8 & 185 & 11 & 190 & 6 & 198 & 25 & 191 \\
\hline \multicolumn{9}{|c|}{ Репродуктор СВПК“ Перемога “ } \\
\hline Ахіллеса 369 & - & - & - & - & 39 & 203 & 39 & 203 \\
\hline Абрікота 58311 & - & - & - & - & 49 & 197 & 49 & 197 \\
\hline Усього & - & - & - & - & 88 & 200 & 88 & 200 \\
\hline \multicolumn{9}{|c|}{ Племрепродуктор СФГ " Поточище " } \\
\hline Лаур 8779 & - & - & - & - & 17 & 183 & 17 & 183 \\
\hline Хорну 8533 & - & - & - & - & 39 & 185 & 39 & 185 \\
\hline Абрікота 58311 & - & - & - & - & 15 & 195 & 15 & 195 \\
\hline Усього & 36 & 186,5 & 57 & 195 & 81 & 187,6 & 81 & 187,6 \\
\hline
\end{tabular}

Дослідженнями встановлено (табл.2), що молочна продуктивність м'ясних корів в III лактації (лінія Ахіллеса 369), складає 219 кг, що на 30 кг $(4,0 \%)$ більше від ровесників першої лактації даного створеного зонального типу сименталу худоби. Жива маса телят за всіма лактаціями відповідає стандарту і еліта класів згідно нових вимог (інструкції) для створюваного буковинського зонального тип м'ясного сименталу нової генерації.

Висока енергія росту притаманна третій лактації лінії Абрікота 5831, складає 211кг, що на 8 кг (4\%) менше від ровесників вище вказаної лактації лінії Ахіллеса 369. Молодняк м'ясного комолого сименталу худоби різної селекції характеризується відносно високою енергією росту в 210 днів, що характерно для вирощування в зоні Карпат.

Вже 20 років розводиться новий типу м'ясного сименталу худоби на Буковині, що відбилось на їх екстер'єрних конституціональних особливостях, який має м'ясний тип 3 ухилом до м'ясного напряму продуктивності. Починаючи з 2012 року племінний завод ДП «ДГ «Чернівецьке» Буковинської ДСГДС НААН» щорічно реалізує племінний молодняк в живій вазі на суму понад 700 тис. грн., що складає $30 \%$ рентабельності. Досягаються показники середньомісячного приросту 900-950 г за повний цикл вирощування із низькими затратами кормів - 7,8 -8,5 к. од. на 1 кг приросту. Так собівартість виробництва яловичини на пасовищах в ДП ДГ “Чернівецьке” в 2015 році становила 1100 грн. що на 350грн. більше ніж у 2011 році, що вплинуло на здешевлення собівартості однієї кормової одиниці.

Ведучий та діючий у Західному регіоні України племінний завод ДП «ДГ «Чернівецьке» Буковинської ДСГДС НААН» кожного року успішно реалізує понад 25- 35 голів молодняку. Так у 2017 році було продано 50 голів племінних телиць класу першого і еліта, а у 2019 році продано 27 телиць та 4 бугайці господарствам різних форм власності Карпатського регіону України, що свідчить про високий попит на худобу виведеного нової генерації м'ясного сименталу худоби для Карпатського регіону України. 
Таким чином забезпечення передумов рентабельного ведення м'ясного скотарства, можливе лише на основі раціонального поєднання ефективного використання виробничого потенціалу і наявних природно - кліматичних зон регіону за умови застосування господарством науково обґрунтованої раціональної структури посівних площ, зональної спеціалізації, впровадження інтенсивних технологій розведення, вирощування, годівлі та утримання тварин з одержання рентабельної галузі м'ясного скотарства в умовах Південно західного лісостепу України.

\title{
Список використаних джерел:
}

1. Калинка, А. К., Лесик, О. Б. \& Шпак, Л. В. (2019). М'ясні симентали нової популяції на Буковині. Problems and achievements of modern science: coll. of scientific papers "АОГОГ» with materials of the International scientific-practical conf. (Vol. 5, pp. 77-82), May 6, 2019. Cork, Ireland: NGO European Scientific Platform.

2. Калинка, А. К, Лесик, О. Б., Шпак, Л. В. \& Казьмірук, Л. В. (2019). Популяція симентальської худоби в Карпатах. Wiadomości o postępie naukowym i rzeczywistych badaniach naukowych

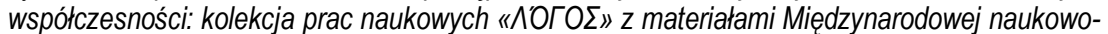
praktycznej konferencji (T. 3, s. 95-99), 17 czerwca 2019 r. Kraków, Polska: OP Europejska platforma naukowa.

3. Калинка, А. К. \& Шпак, Л. В. (2005). Эфффективность выпасания мясного скота в предгорье Карпат. Зоотехния, (5), 9-10.

4. Калинка, А. К. \& Шпак, Л. В. (2008). Интенсивное выращивание молодняка крупного рогатого скота в условиях передгорья Карпат. Зоотехния, (2), 19.

5. Калинка, А. К. \& Драб, В. С. (2009). Сучасне м'ясне скотарство Буковини. Тваринниитво України, (5), 14.

\section{ОКУПАЦІЯ РЕГІОНАЛЬНОГО ЛАНДШАФТНОГО ПАРКУ «ЗНЕСІННЯ» КОМЕРЦІЙНОЮ АВТОСТОЯНКОЮ}

\author{
Тарас Уляна Михайлівна \\ канд. с.-г. наук, директор \\ Регіональний ландшафтний парк «Знесіння» \\ Мекекечко Максим Валерійович \\ юристконсульт \\ Регіональний ландшафотний парк «Знесіння» \\ УКРӒ̈HA
}

Мета статті: Підняти актуальність та розуміння глобальность земельних спорів як в РЛП «Знесіння», так і для інших об'єктів природно-заповідного фонду України та світу. Висвітлити слухачам практичні знання, навички та юридичні прийоми із захисту земельних прав РЛП «Знесіння» в судових провадженнях. I на останнє, надати усвідомлення важливості відстоювання прав та інтересів земель РЛП «Знесіння», як особливо цінних надбань природи.

Об 'єкти природно-заповідного фонду України (ПЗФ), як важливі складові екосистеми, мають особливе правове регулювання, яке забезпечує належну 
підтримку фауни і фрлори, функціонування рекреаційної складової та захисту особливо цінних територій природи. Таким об 'єктом ПЗФ являється Регіональний ландшафтний парк «Знесіння» (РЛП «Знесіння або парк). Його протяжність сягає 312,0949 га (зовнішня межа), що є найбільшим серед 32-ох об 'єктів ПЗФ у м. Львові.

Утворення РЛП «Знесіння» припадає на 1993 рік, в якому Львівська обласна рада оголосила територію об 'єктом природно-заповідного фонду України. Проте, чітко визначених меж території на той час ще не існувало. Розуміючи це, з 1997 року дирекцією РЛП «Знесіння» велась активна робота по виготовленню технічної документації на земельні ділянки, що лягли в основу чинного Державного акту на право постійного користування землею виданого парку. Відповідно до Державного акту І-ЛВ № 004103 РЛП «Знесіння» надано у постійне користування 153,6903 га земель. Саме від цього моменту розпочався етап правового регулювання земель парку, а за ним найбільші (резонансні) земельні спори з власниками суміжних земельних ділянок. Одним 3 найнебезпечніших таких спорів, що тягнеться по сьогодення, $є$ спір про земельну ділянку по вул. Харківській, 42-44 у м. Львові заг. площею 0,4683 га.

Згідно державного акту І-ЛВ № 004103, виданого на підставі ухвали Львівської міської ради № 1113 від 21.06.2001 р., дана земельна ділянка надана парку на праві постійного користування та використовується у природоохоронних цілях. Та все це не завадило Підприємству гаражного i технічного обслуговування «Сервіс» (ПГ і ТО «Сервіс») Всеукраїнської спілки автомобілістів та Приватному підприємству «Факторія» (ПП «Факторія) використовувати земельну ділянку під комерційну автостоянку.

У 2016 році Регіональний ландшафтний парк «Знесіння» звернувся до Господарського суду Львівської області з позовом про зобов 'язання ПГ і ТО «Сервіс» та ПП «Факторія» звільнити самовільно зайняту земельну ділянку заг. площею 0,4683 га по вул. Харківська 42-44 у м. Львові. Згідно з ст. 1 Закону України (ЗУ) «Про державний контроль за використанням та охороною земель» самовільне зайняття земельної ділянки - це будь-які дії, які свідчать про фрактичне використання земельної ділянки за відсутності відповідного рішення органу виконавчої влади чи органу місцевого самоврядування про їі передачу у власність або надання у користування (оренду) або за відсутності вчиненого правочину щодо такої земельної ділянки, за винятком дій, які відповідно до закону є правомірними. Оскільки ПГ і ТО «Сервіс» та ПП «Факторія» не мала жодного правовстановлюючого документу на земельну ділянку та використовувала землі парку під автостоянку, позов був підставним і ґрунтованим на законі. Не було сумнівів, що це було самовільне зайняття земельної ділянки парку. До того ж, РЛП «Зенсіння» долучив топографічний план земельної ділянки по вул. Харківській 42-44, що є беззаперечним доказом, який встановлює факт самовільного зайняття земельної ділянки під комерційну автостоянку.

У ході одного із судових засідань, клопотанням представника ПП «Факторія», суд долучив копію рішення Господарського суду Львівської області справі № 19/36 від 01.04.2008 року. Особливість цього рішення в тому, що воно було надруковане з нечитабельним текстом. Як на принтері у якого закінчується фрарба. А тому, ніхто не зміг ознайомитись з його змістом. А ні 
представник РЛП «Знесіння», а ні представник Львівської міської ради та третьої особи, яка виступала на стороні захисту інтересів парку. Це був юридичний трюк. Саме це рішення, стане вирішальним і найнебезпечнішим в подальшому для Державного акту на землі надані у користування парку.

За результатами розгляду справи, рішенням у справі № 914/4407/15 від 05.05.2016 р., суд відмовив у задоволення позову парку виходячи з наступних підстав:

1) Згаданим рішенням від 01.04.2008 року у справі 19/36, яке було долучено до матеріалів справи, визнано право власності за ГО «Всеукраїнською спілкою автомобілістів» на автостоянку № 3 по вул. Харківській, 42-44 у м. Львові, яка згодом продала ії за договором купівліпродажу від 30.12.2008 р. ПП «Факторія».

2) Суд безпідставно встановив відсутність фракту самовільного зайняття земельної ділянки незважаючи на те, що автостоянка використовується ПП «Факторія» без належних правовстановлюючих документів на землю.

По суті рішення від 01.04.2008 р., що було прийняте без участі законного користувача землею РЛП «Знесіння», стало підставою для рейдерського захвату земель ПЗФ під комерційну автостоянку. Так як, відмова суду в задоволені позову у справі № 914/4407/15 ґрунтувалась на рішенні від 01.04.2008 року у справі № 19/36, постало питання про оскарження рішення останнього.

Ознайомившись 3 матеріалами справи № 19/36, представник парку дійшов до висновку про його незаконність та необґрунтованість. Суд незаконно визнав право власності за Всеукраїнською спілкою автомобілістів на підставі документів про передачу на баланс автостоянки. Крім того, згідно ст. 104 Господарського кодексу України (ГПК України), підставою для скасування або зміни рішення суду є порушення норм процесуального права. Відповідно до ч. 2 ст.104, порушення норм процесуального права $€$ в будь-якому випадку підставою для скасування рішення місцевого господарського суду, якщо господарський суд прийняв рішення про права і обов 'язки осіб, що не були залучені до участі у справі.

Враховуючи це, РЛП «Знесіння» подав апеляційну скаргу на рішення у справі № 19/36 від 01.04.2008 р. з проханням поновити строк на апеляційне оскарження та скасувати його повністю. Строк на апеляційне оскарження цього рішення був пропущений через маніпуляції ПГ і ТО «Сервіс» та ПП «Факторія» з долученням тої самої нечитабельної копії рішення суду, яка не дозволяла ознайомитись з його з змістом. А згідно ст. 93 ГПК України (чинного на момент оскарження), апеляційна скарга подається на рішення місцевого господарського суду протягом 10 днів, з дня його оголошення. Незважаючи на вказані поважні причини пропуску строку на оскарження, Львівський апеляційний господарський суд прийняв рішення відмовити в поновленні пропущеного строку на оскарження рішення у справі № 19/36.

Станом на сьогодні, в провадженні Господарського суду Львівської області перебуває справа за позовом вже ПП «Факторії» до РЛП «Знесіння» та Львівської міської ради про визнання права користування земельною ділянкою; про визнання недійсною та скасування ухвали Львівської міської 
ради № 1113 від 21.06.2001 р. та Державного акту на постійне користування землею, виданого на підставі неї.

Саме цей спір створює особливо велике занепокоєння за долю земель РлП «Знесіння». Оскільки скасувати Державний акт в частині виключення автостоянки не можливо, існує велика загроза ліквідації всіх земель наданих у постійне користування РЛП «Знесіння».

Але це однозначно не кінець. Наразі готова одна юридична стратегія, яка здатна захистити землі РЛП «Знесіння» від їх повної ліквідації. А саме Львівська міська рада та РЛП «Знесіння» підготували позов до ГО «Всеукраїнська спілка автомобілістів» та ПП «Факторія» по-перше, про скасування рішення державного реєстратора обласного комунального підприємства Львівської обласної ради «Бюро технічної інвентаризації та експертної оцінки» (ОКП ЛОР «БТІ та ЕО») від 28.05.2008 р. про державну реєстрацію права власності за ГО «Всеукраїнська спілка автомобілістів» на автостоянку. По-друге, про визнання недійсним договору купівлі-продажу автостоянки, укладений від 30.12 .2008 р. 3 ПП «Факторія» та ГО «Всеукраїнською спілкою автомобілістів». I на останнє, про скасування рішення приватного нотаріуса від 06.04.2009 р. про державну реєстрацію права власності ПП «Факторія» на автостоянку.

Нагадаємо, що підставою виникнення права власності на автостоянку слугувало рішення господарського суду Львівської області від 01.04.2008 у справі №19/36. При цьому, згідно із висновками суду автостоянка №3, що знаходиться на вул. Харківській, 42-44 у м. Львові не визнана об'єктом нерухомого майна. У відповідності до вимог 1.6 Тимчасового положення про порядок реєстрації прав власності на нерухоме майно, затвердженого наказом Міністерства юстиції України від 7 лютого 2002 року №7/5 (чинним на час виникнення спірних правовідносин), передбачено, що державну реєстрацію прав власності на нерухоме майно здійснюють підприємства бюро технічної інвентаризації у межах визначених адміністративно-територіальних одиниць.

Реєстрації підлягають права власності тільки на об'єкти нерухомого майна, будівництво яких закінчено та які прийняті в експлуатацію у встановленому порядку, за наявності матеріалів технічної інвентаризації підготовлених тим БTI, яке проводить реєстрацію права власності на ці об'єкти. При цьому зазначено, що не підлягають реєстрації тимчасові споруди, а також споруди, не пов'язані фрундаментом із землею. Тобто реєстрації підлягали саме капітальні споруди, на які може бути видано окреме свідоцтво про право власності.

Так, в ході розгляду судової справи №19/36 не досліджувалось питання будівництва вказаної автостоянки та прийняття ії в експлуатацію у встановленому для об'єктів нерухомого майна порядку. В резолютивній частині рішення суду не вказано, що зазначена автостоянка $є$ об'єктом нерухомого майна та його площа становить 17,7 кв.м. Рішенням суду визнано право на автостоянку, а не на нежитлове приміщення площею 17,7 кв.м.

Враховуючи це, вважаємо, що приміщення для охорони на автостоянці встановлено як тимчасову споруду без фундаменту, а отже таке не може бути визнано капітальною спорудою, на яку видається окреме свідоцтво про право власності, а тому недійсними є і правочини щодо відчуження цього об'єкта. 
Зі змісту заяви ГО «Всеукраїнська спілка автомобілістів» від 05.05.2008, адресованої ОКП ЛОР «БТІ та ЕО», слідує, що заявник просив виготовити витяг про реєстрацію та витяг з реєстру за адресою: м. Львів, вул. Харківська,44. При цьому, заявник не просив зареєструвати право власності на автостоянку № 3, а просив видати витяг з реєстру, не вказавши на яке майно. Разом 3 тим, як вбачається 3 інформації одержаної з Державного реєстру речових прав на нерухоме майно, на вул. Харківській, 44 у м. Львові розташовано більше 10 гаражних боксів, що належать на праві приватної власності фізичним особам.

Таким чином, державний реєстратор Обласного комунального підприємства Львівської обласної ради «Бюро технічної інвентаризації та експертної оцінки», не встановив відповідності заявлених прав і поданих документів вимогам законодавства, не перевірив наявності підстав для відмови в державній реєстрації прав, не надав оцінки наявним суперечностям між заявленими правами та документами, поданими для державної реєстрації прав, оскільки рішенням суду визнано право власності на автостоянку, яка, відповідно до вимог чинного законодавства, не є об'єктом нерухомого майна, в рішенні суду жодним чином не згадується такий об'єкт нерухомого майна, як "автостоянка №3 загальною площею 17,7 кв.м ", на який зареєстровано право власності ОКП ЛОР «БТІ та ЕО».

Враховуючи наведене, реєстратором ОКП ЛОР «БТІ та ЕО» в порушення встановленого порядку зареєстровано право власності на неіснуючий об'єкт нерухомого майна без будь-яких правовстановлюючих документів на такий, внаслідок чого обтяжено земельну ділянку та порушено право територіальної громади на вільне розпорядження землями комунальної власності, а також право користування Регіонального ландшафртного парку "Знесіння" зазначеною земельною ділянкою.

Зважаючи на те, що первинне право власності на автостоянку на вул. Харківській, 44 зареєстровано за ГО «Всеукраїнська спілка автомобілістів» протиправно, то подальше відчуження цього об'єкта є незаконним, а укладені договори купівлі-продажу підлягають визнанню недійсними.

Враховуючи наведену позицію, РЛП «Знесіння» повинно реабілітувати своє законне право на використання землі ПЗФ по вул. Харківській, 42-44, окупованою під комерційну автостоянкою.

\section{Список використаних джерел:}

1. Ухвала Львівської міської ради, № 1113 від 21.06.2001 р. (2001).

2. Державний акт на право постійного користування землею I-ЛВ № 004103.

3. Рішення Господарського суду Львівської області, у справі № $19 / 36$ від 01.04 .2008 р. (2008).

4. Рішення Господарського суду Львівської області, у справі № 914/4407/15 від 05.05.2016 р. (2016).

5. Про державний контроль за використанням та охороною земель (Самовільне зайняття земельної ділянки) (Витяг із ст.1 Закону України).

6. Господарський процесуальний кодекс України (ст. 104).

7. Про порядок реєстрації прав власності на нерухоме майно (Тимчасове положення, затверджене наказом Міністерства юстиції України) №7/5, від 7 лютого 2002 року. (2002). 


\title{
SECTION III. \\ ENGINEERING AND IT
}

DOI 10.36074/25.10.2019.v1.07

\section{APPLICATION OF SPLINES UNDER TENSION FOR SIMULATION OF THE STRESSED-DEFORMED CONDITION OF THE LINEAR PART OF THE MAIN PIPELINES}

\begin{abstract}
Boris Nezamay
Candidate of Technical Sciences, lecturer in the Department of Applied Mathematics Ivano-Frankivsk National Technical University of Oil and Gas

Sergiy Babchuk

Candidate of Technical Sciences, lecturer in the Department of Computer Engineering Ivano-Frankivsk National Technical University of Oil and Gas
\end{abstract}

UKRAINE

There is a problem of modeling its stress-strain state in the analysis of the technical condition of the linear part of the main pipelines. For this purpose the methods of interpolation with classical cubic spline and cubic spline with smoothing are used [1]. There are several disadvantages to this approach. The proposed technique assumes a voltage proportional to the second derivative of the model curve [2], which is here piecewise linear, which leads to deviations from the real physical picture of the process. An alternative is to use tension splines [3], with a minimum of functional of the form:

$$
\Phi_{1}(u)=\int_{a}^{b}\left\{\left[u^{\prime \prime}(x)\right]^{2} \cdot A+\left[u^{\prime}(x)\right]^{2} \cdot B\right\} d x,
$$

Where $A$ and $B$ are some constant values. This problem is the task of interpolation by a cubic spline, if $B=0$. And the problem is the task of piecewise linear interpolation, if $A=0$.

The line that delivers the extremum (1) is called a spline under tension because the minimization condition is written in the form:

$$
A u^{(I V)}-B u^{\prime \prime}=0 \text {, }
$$

The solution (2) is written as:

$$
u(x)=C_{1} \cdot e^{k x}+C_{2} \cdot e^{-k x}-\frac{C_{3}}{k^{2}} x-\frac{C_{4}}{k^{2}} .
$$

It is suggested to use the least squares method to determine the coefficients in the formula (3).

By representing the radius vector of pipeline points according to the known method [2], the discrepancy equilibrium equation of the system is calculated. 
There is a suggestion to minimize the discrepancy about some parameter that can enter:

- as a constant, in this case the computational algorithm will be simplified as much as possible;

- as a function of the length of the considered, inversely proportional to the displacement of the points of the pipeline section. This approach should make it possible to separate the effect of stress-strain state of deformation and displacement;

- as a function of length and time. This approach can provide a model of the change in stress in the pipeline body due to periodic processes, such as daily changes in temperature.

Thus, the use of a spline under tension to reproduce the spatial position of pipelines using information on longitudinal stresses at the points of the pipeline body will allow to obtain more accurate models of deformation of pipelines, to more accurately establish the stress-strain state and create conditions for modeling external influences on the pipeline based on their quality evaluation.

\section{References:}

1. Olijnik, A. P. (2004). The curvilinear cylindrical bodies axes interpolation method design using the information about displacements and bodies loading methods. Solid state physics and chemistry, (4/5), 859-862.

2. Olijnik, A. P. (2010). Mathematical models of quasi-stationary deformation of pipeline and industrial systems when changing their spatial count configuration. Ivano-Frankivsk: IFNTUOG.

3. Cline, A. (1974). Curve fitting in one and two dimensional spaces using splines under tension. Comm. ACM 17, 218-223.

\section{BERRY POWDERS WITH A HIGH CONTENT OF PTEROSTILBENE AND RESVERATROL IN THE TECHNOLOGY OF CHOCOLATE FLOUR CONFECTIONERY}

\section{Yehor Polyvanov}

student

Oles Honchar Dnipro National University

Alisa Kogan

student

Oles Honchar Dnipro National University

Scientific advisor: Nataliia Kondratiuk

Associate Professor, Ph.D. (Engineering), Head of the Department of Food Technologies

Oles Honchar Dnipro National University

UKRAINE

In the 21st century, scientists, technologists, nutritionists and doctors have been rising active discussions about the anti-aging of the body, the popularization of proper nutrition and a healthy lifestyle among all segments of the population. Today, the labor costs of the planet's population significantly exceeds the allotted norms. 
People devote more time to work, study, daily problems, communication in networks, which, consequently, leads to stress, lack of sleep, indigestion, various diseases and early aging of organs and systems.

Scientists cannot accurately indicate the factors that lead to Alzheimer's, Parkinson's, Crohn's, oncological diseases, and type 2 diabetes. However, there is a consensus - this is a malnutrition, and, as a consequence, a reduced amount of biostimulant nutrients of metabolic processes in the diet. In 2018, it was recorded that 50 million people suffer from dementia (an irreversible loss of mental ability). Unfortunately, in 2050 this number can triple. In 2014, 422 million people were recorded struggling with type 2 diabetes, as its consequences. Crohn's disease affects from 2 to 4 people per 100 thousand inhabitants per year. These frightening statistics became the motive to develop approaches to change diets and / or create products that would allow people to be removed from the risk groups in a short time. We have analyzed an extensive flow of information, which allowed us to draw up a certain picture of events and come to interesting conclusions. Exceeding the contact time with the information field leads to a lack of time to organize proper nutrition at home or on the side. As a result, in most cases one begins to use semi-finished products (frozen, sauce, high-level preparedness, etc.) or pre-made meals (yogurts, cookies, sausage, processed cheeses, bakery products, sweets, etc.) and completely forgets about the importance of consuming fruits, berries, vegetables sources of biostimulant substances that regulate the processes of metabolism and aging.

According to the results of our analytical study, the enrichment of many premade products with fruit and berry modules form is either impossible (due to the subsequent decrease in $\mathrm{pH}$, the need to add sugar, change color, taste and smell, violation of rheological parameters), or is impractical (for example, enrichment of meat or fish semi-finished products with berries or fruits).

Therefore, we proposed a dry mix technology for the preparation of chocolate muffins, pancakes with the addition of dry berry powder from blueberries and / or bilberries and / or peels of dark grape varieties, as sources of biologically active substances such as pterostilbene and resveratrol. Pterostilbene - a derivative of trans-stilbene located in blueberries - has a beneficial effect on the cardiovascular system, central nervous system, has antioxidant, anti-inflammatory properties, and inhibits cancer growth. In addition, it reduces insulin resistance, glucose levels and cholesterol. The experiments showed that pterostilbene has the ability to pass through the blood-brain barrier, which, in turn, is a diffusion barrier necessary for the normal functioning of the central nervous system. Its advantage, in addition, is that it is able to absorb free radicals and protect biomolecules from oxidative effects. According to some studies, the use of pterostilbene enhances the effectiveness of immunotherapy, especially in the cancer treatment [1].

Pterostilbene also activates the synthesis of sirtuin in the human body - a protein that is responsible for aging and DNA repair. Pterostilbene has a beneficial effect as anti-aging compounds, modulating signs of aging, including oxidative damage, inflammation, telomere depletion, and cell aging [2]. Resveratrol - has the same structure as pterostilbene, but due to the absence of methoxylated groups, it is less actively absorbed in body, however, like pterostilbene, it also has antitumor, chemoprotective, and chemosensitizing properties that increase the sensitivity of cancer cells to chemotherapy. In addition, resveratrol has many other advantages in reducing neurodegenerative diseases, reducing weight by reducing lipogenesis, 
70 - Scientific discoveries: projects, strategies and development $\bullet$ Volume 1

and other relevant applications, such as treatment of skin hyperpigmentation [3], type 2 diabetes [4], Parkinson's and Alzheimer's disease [5].

Conclusion: The developed technology of chocolate flour confectionery with freeze-dried powders of blueberries, bilberries and peels of dark grapes allowed us to expand the range of products that allow for a full snack for many categories of the population, have become interesting for $\mathrm{HoReCa}$ and many retail chains. The content of biologically active substances does not exceed $50 \%$ of $\mathrm{RSH}$ for an adult.

\section{References:}

1. Polyvanov, Y. \& Kogan, A. (2019). Evaluation of the relevance of the development of food modules with pterostilbene and resveratrol of natural origin. «Dynamics of the development of world science» Abstracts of I Int. Scientific and Pract. Conf., 248-250.

2. Wenzhe, Yu. \& Xiaogian, Hu. \& Mingfu, W. (2018). Pterostilbene inhibited advanced glycation end products (AGEs)-induced oxidative stress and inflammation by regulation of RAGE/MAPK/NF-KB in RAW264.7 cells. Journal of Functional Foods, (40), 272-279. doi: 10.1016/j.jff.2017.11.003.

3. Moshawih S., Mydin, R.B.S.M.N., Kalakotla, S. \& Jarrar, Q.B. (2019). Potential application of resveratrol in nanocarriers against cancer: Overview and future trends, J. of Drug Delivery Science and Technology, (53). doi: 10.1016/j.jddst.2019.101187.

4. Rašković, A. \& Ćućuz, V. \& Torović, L. (2019). Resveratrol supplementation improves metabolic control in rats with induced hyperlipidemia and type 2 diabetes. Saudi Pharmaceutical Journal. doi: 10.1016/j.jsps.2019.08.006.

5. Chen, J.-Y., Zhu, Q., Zhang, S., OuYang, D. \& Lu, J.-H. (2019). Resveratrol in experimental Alzheimer's disease models: A systematic review of preclinical studies. Pharmacological Research, (27), 1481-1493. doi: 10.1016/j.phrs.2019.104476.

DOI 10.36074/25.10.2019.v1.08

\section{COIL TUBING TECHNOLOGIES: A HISTORY OF DEVELOPMENT AND APPLICATION IN POLTAVA REGION}

Dyachenko Yulya

Operational disciplines' lecturer

Poltava Oil and Gas College of Poltava National Technical Yuri Kondratyuk University

Helen Zotova

Head of Operation Department, Economic disciplines' lecturer, Poltava Oil and Gas College of Poltava National Technical Yuri Kondratyuk

University

UKRAINE

A promising area of specialized equipment application for petroleum industry today is coil tubing technology [1].

Coiled tubing drilling (from Eng. Coiled tubing drilling - column of flexible pipes) is required a specialized oil and gas technologies, which are innovative.

Coil tubing is widely used in technological as repair and restoration works performed on oil, gas and gas condensate wells [1]. 
The global experience in the use of flexible pipe columns has repeatedly confirmed in practice the benefits of using coil tubing technologies over traditional overhaul of gas and oil wells.

For the first time, the use of long-range flexible pipes was made during the operation to force the English Channel during the landing of Allied troops in France during the Second World War. To secure the supply of troops, 23 strands of pipelines were deployed on the bottom of the duct: 6 pipelines were steel with an internal diameter of $76.2 \mathrm{~mm}$ and the rest were of composite construction. Laying of steel pipelines was carried out from floating coils with a diameter of the order of $12 \mathrm{~m}$. They were wound sections of pipelines with a length of $1220 \mathrm{~m}$. Each section, in turn, consisted of welded butt pipes of length $6.1 \mathrm{~m}$.

Coil tubing technology was invented in the 1950s. However, this technology became widely used only in the late 1980s. This technology is cheaper and more environmentally friendly than classic drill pipe columns [2].

This technology was the basis for the manufacture of flexible continuous pipes columns in the initial period of work on the fishery. It was first made by Creat Lakes Steel Co (USA) in 1962. Pipes with a diameter of $33.4 \mathrm{~mm}$ and a wall thickness of $4.4 \mathrm{~mm}$ were welded in an atmosphere of inert gas at the end of 15 pieces. The manufactured pipe was wound on a coil with a core diameter of $2.7 \mathrm{~m}$.

Flexible pipe technology has been constantly refined, but only by the end of the 1970s did their quality meet the requirements needed for oil and gas operations.

At the same time, Canadian specialists were creating flexible pipes for drilling wells. By 1976, Flex Tube Service Ltd manufactured used in drilling a flexible steel column with a diameter of $60.3 \mathrm{~mm}$, which was wound on a coil with a core diameter of about $4 \mathrm{~m}$ and consisted of welded butt joints of 12-meter pipes. Specialists of the same company made a column of drill pipes with a diameter of 60.3 aluminum. Work on the creation of pipes of this design was halted because of their low durability, in which the descent to the depth of the column is possible only up to 900 $\mathrm{m}$. cross joints, as well as improving the design of the joint itself.

By 1983, using tape blanks from Japan, Quality Tubing Inc (USA) specialists managed to increase the length of the whip to $900 \mathrm{~m}$. The joints of individual whip joints were performed before the ribbon was fed into the pipe bending machine, which significantly improved the quality of the pipes. The outer diameter of the latter was increased to $89 \mathrm{~mm}$.

By 1991, the depth of descent flexible tube column (CGT) had increased to 5200 $\mathrm{m}$, and in 1995 the production of pipes with outer diameter was started $114.3 \mathrm{~mm}$.

Today, the monopoly in the field of design and manufacture of coil tubing equipment belongs mainly to U.S. and Canadian companies [3].

All companies can be divided into four groups:

1. Large multidisciplinary corporations and companies with extensive structure and many years of experience in mass production of oil and gas equipment and coil installations. They have a complete cycle of their own production of equipment and occupy a leading position in the international market of manufacturers and suppliers. These include: Hydra Rig (National Oilwell-Varco), USA. This company has complete own production and is the world leader in volume of production and sales. 
2. Medium-sized companies that have a stable position and development prospects also have full own production and perform in the regional markets of supply of equipment in their own name. These include: Hydraco Industries, Canada, Hydraulic Power Technology Texas, USA, Crown Energy Technologies, Canada.

3. Medium-sized companies capable of producing installations almost entirely on the basis of their production, but produce their main subsystems under their trademark. The capabilities of these companies allow you to deploy a complete unit manufacturing cycle: Pump And Coiled Tubing (part of MXROS Inc.), USA, Aggreko Special Equipment Productions, Netherlands.

4. Small companies that produce separate subsystems and units for coil tubing forming plants and often act under the name of the customer.

Today, coil tubing technologies are widespread in the oil and gas industry [4].

Every year, the spectrum of application of coil tubing technologies in Ukraine, and in particular in Poltava region, is expanding. For more than a decade, in the field of oil and gas production, these technologies have been used to perform various operations in the process of development and operation of oil and gas fields, including drilling. They allow the repair of oil and gas wells under pressure without interrupting their operating mode. In addition, these technologies are used in injection wells, drilling operations, the development of wells, geophysical and other works.

While more than 50 years have been used to produce and operate various types of coils, they are still not manufactured in our country. In Ukraine, over 10 years, foreign coil tubing is used for major repairs and drilling of wells. The installations differ in configuration, technological capabilities and price.

Coil tubing technology was widely used only in the late 1980s, but it came to us in Ukraine relatively recently.

Of course, such equipment is very complex in terms of design and technology, but Ukraine has qualified design and production personnel, and with appropriate funding it would be possible to create their own models of this technique [5].

The development of Ukraine's gas industry has opened doors for foreign companies. With them come to Ukraine modern technologies that greatly facilitate and improve the work of gas producers, in particular - coil tubing.

In Ukraine there are five major companies providing coil tubing services, such as: «UGV-SERVICE» JSC «Ukrgazvydobuvannya», LLC «BTF-COILTUBING», LLC «POLTAVA DRILLING COMPANY», LLC «SERVICE OIL», «Schlumberger Services Ukraine».

JSC Ukrgasvydobuvannya develops the gas, oil and oil and gas condensate deposits in Kharkiv, Poltava, Sumy, Donetsk, Luhansk, Dnipropetrovsk, Lviv, IvanoFrankivsk, Zakarpattia, Chernivtsi and Volyn regions. The Company's geological exploration of new hydrocarbon deposits is carried out in the Dniprovsko-Donetska cavity and the Carpathian Mountains.

For example, the UGV-Service by the result in 2018 achieved an increase in natural gas production at existing fields through the conduct of 729 coil tubing operations.

Among them, one of the largest service companies in the world «Schlumberger». 
«Schlumberger» is the world's largest provider of geological modeling, drilling, production and refining technologies for the oil and gas industry. The company operates in 85 countries. "Schlumberger» is a world class service.

Just a year ago, the company entered the Ukrainian market with an expanded range of services. Last October, Ukrgasvydobuvannia ordered high-tech services using coil tubing and engineering support from Schlumberger. It is from that time on that the world-renowned company began to bring coil tubing plants to Ukraine.

Today Schlumberger representatives are actively introducing their own technologies in the eastern part of the country. In particular, in the fields of Poltava region [6].

Ukrgasvydobuvannia is convinced that cooperation with Schlumberger will allow access to the high-tech solutions needed to achieve the goals of the country's energy complex.

In Ukraine, most of the deposits have been exploited for a long time, with the result that their level of depletion reaches $80 \%$. In order to maximize production at such fields, efficient technologies must be implemented, that is coil tubing. But it is possible to increase the volume of hydrocarbons only by exploring new deposits. The search for natural gas also requires the involvement of new approaches and international expertise.

\section{References:}

1. Biletsky, V., Orlovsky, V., Dmytrenko, V. \& Pokhylko, A. (2017). Fundamentals of oil and gas

2. business. Poltava: PoltNTU4 Kyiv: FOP Khalikov R.

3. Biletsky, V., Orlovsky, V. \& Vitryk, V. (2018). Fundamentals of oil and gas engineering: textbook for students. spec. 185 "Oil and gas engineering and technologies". Poltava: ASMI LLC.

4. Moishevych, L. (2016). Application of Flexible Tube Columns in the Oil and Gas Sector and Catching with them. Oil and Gas Science - Education - Production: Ways of Integration and Innovative Development: Proceedings of the All-Ukrainian Scientific and Technical Conference. Drohobych, Ukraine: Track-LTD.

5. Zotova, H. \& Dyachenko, Yu. (2019). Coiled tubing as a modern technology in oil-and-gas production. Development of modern technologies and scientific potential of the world: call of

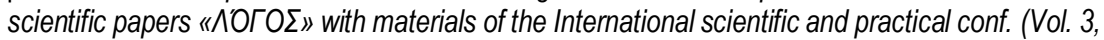
pp. 77-79), July 29, 2019. London, UK: NGO European Scientific Platform. Retrieved from https://ojs.ukrlogos.in.ua/index.php/conferences/issue/view/6/5.

6. Babayev, V., Chervinsky V., Melnyk R. (2017). Peculiarities of application of coil tubing technologies for overhaul of wells. Proceedings of the International Oil and Gas Energy 2017 Scientific and Technical Conference. Ivano-Frankivsk, Ukraine: IFNTUNG.

7. Poltava Oblast Internet News: Poltava News (2019). The Koltubing Era - How Ukraine Introduces Modern Technologies in the Gas Industry Retrieved from https://poltava.to/project/5545/. 


\title{
DIFFERENTIATION OF VULKAN API, OPENCL, AND OPENGL FOR RAY TRACING ALGORITHMS
}

\author{
Oleksii Denysenko \\ Software Developer \\ SP Denysenko \\ UKRAINE
}

Introduction. People started using GPUs for the performance of calculation quite a long time ago. The so-called multi-core processors that perform parallel computing have fairly high performance. GPU technologies have become widespread quite recently, and their latest models have a sufficiently flexible architecture, which can be used to perform both more complex and simple graphical tasks.

Task setting. Optimal construction of three-dimensional images is one of the main tasks of modern programs. There is a large number of frameworks in which image-building techniques are implemented, including Open CL, OpenGL, and Vulkan APIs. Therefore, the task was set to compare these interfaces for the solution of the problem of ray tracing.

The main material. In the process of studying the aforementioned frameworks

it has been found that Vulkan API has the following advantages over its competitors:

1. The use of SPIR-V format, in which HLSL shaders are compiled, which allows one to compile them during development and to describe them using an arbitrary programming language;

2. Widespread support for this API - from cell phones to high-end graphics cards;

3. Support for modern multi-threaded systems;

4. Reduced CPU load in situations in which its performance is insufficient. This leads to an increasein bandwidth during visualization and computation operations [1];

5. Memory allocation and its distribution for certain tasks is done by the developer, based on their own knowledge. Thismemory management option is used for the following reasons:

- reduced memory allocation costs due to the absence of costly automatic operations;

- ease of use of existing allocation options;

- objects in a non-volatile memory section use cache better;

- data processing speed is increased [2].

6. Vulkan API pipeline settings are fixed in a single object, which improves the ease of use;

7. Presence of a render pass graphic object. Render pass is intended for grouping drawing calls that are processed together into separatesub-passes. Even though this advantage in not relevant in computer gaming, according toAMD, some 
optimizations can be made using render pass. Render pass also manages frame buffer textures, sub-passes synchronization, and multisampling resolution.

8. Since asynchronous operation of the GPU is implemented in Vulcan, all dependenciesbetween buffers must be clearly described. There are also four levels of synchronization:

- semaphore - the most widely used mechanism, which signals completion of buffer operation and allows the start of operation of the next buffer;

- fences - is used to notify a program about actions performed by the semaphore mechanism;

- events - is used for the synchronization of a certain place in the control buffer;

- pipeline barrier - performs the process of synchronization of the next commands in the buffer with execution.

Conclusion. Thus, we can conclude that the use of Vulkan API to build a ray tracing algorithm for building three-dimensional images is one of the most promising methods in modern computer graphics. The use of this method allows one to achieve maximum efficiency in the field.

\section{References:}

1. Nvidia talk Vulkan in a developer blog post. Retrieved from https://www.gamingonlinux.com/articles/nvidia-talk-vulkan-in-a-developer-blog-post-they-sayvulkan-supplements-opengl.6506.

2. Vulkan Memory Management. Retrieved from https://developer.nvidia.com/vulkan-memorymanagement.

\section{DYNAMIC MODEL OF A FOREST TRANSPORT SYSTEM TAKING INTO ACCOUNT THE STOCHASTIC COMPONENT}

RESEARCH GROUP: Irina Enaleeva-Bandura Ph.D. (Engineering), Associate Professor of the Department of "Use of Water Resources" Reshetnev Siberian State University of Science and Technology

Rudolf Kovalev D.Sc. (Engineering), Professor, Professor of the Department of Automotive Engineering Ural State Forestry University

Sergey Brovkin

Student of the Forest Technology Institute Reshetnev Siberian State University of Science and Technology 
76 • Scientific discoveries: projects, strategies and development $\bullet$ Volume 1

\section{Alina Burkina}

Student of the Forest Technology Institute

Reshetnev Siberian State University of Science and Technology

Viktoriya Shuvalova

Student of the Forest Technology Institute Reshetnev Siberian State University of Science and Technology

Snezhana Shtern

Student of the Forest Technology Institute Reshetnev Siberian State University of Science and Technology

RUSSIAN FEDERATION

Research materials and methods. Let us consider the models that are best known in the scientific literature and take into account the uncertainty of input parameters. According to source [17], the objective functional will be defined as follows:

$$
L(X(Z))=\sum_{j=1}^{n}\left[R_{1}\left(Z_{j}\right) \int_{0}^{Z_{i}} \varphi_{j}(\theta) d \theta+R_{2}\left(Z_{j}\right) \int_{z_{j}}^{\infty} \varphi_{j}(\theta) d \theta\right]+\sum_{i=1}^{m} \sum_{j=1}^{n} C_{i j} X_{i j}(Z)
$$

and satisfy the constraints:

$$
\begin{gathered}
\sum_{j=1}^{n} X_{i j}(Z) \leq a_{i}, i=1,2, \ldots n \\
\sum_{i=1}^{m} X_{i j}(Z) \leq Z_{j}, j=1,2, \ldots m \\
\sum_{j=1}^{n} Z_{j}=\sum_{i=1}^{m} a_{i}=A \\
X_{i j} \geq 0, i=1,2, \ldots, m, j=1,2, \ldots n
\end{gathered}
$$

where:

$\theta$ - random demand value,

$\varphi_{j}(\theta)$ - density of distribution of the random demand value for the commodity in the j-shop;

$Z_{j}$ - volume of the commodity order for the j-shop,

$a_{j}$ - payment for the storage of the commodity unit in the $j$-shop;

$\beta_{j}$ - cost of the commodity unit in the j-shop while selling;

$C j$ - purchase cost of the commodity unit;

$Z=\left(z_{1}, Z_{2}, \ldots z_{n}\right)$ - distribution of the commodity order volumes for the total of shops, $j=1,2, \ldots, n$.

At the same time, if the random demand value $\theta$ is less than an ordered commodity volume $Z_{j}$, then there is a necessity of storing unsold commodities. If the demand $\theta$ exceeds the order, then there are losses associated with a deficiency in these commodities. Then, it is evident that average values of storage costs and of losses from the short delivery will be defined by the following expressions:

$R_{1}\left(Z_{j}\right)=a_{j} \int_{0}^{Z_{j}}\left(Z_{j}-\theta\right) \varphi_{j}(\theta) d \theta$ - average costs of the storage of unsold commodities in the $j$-shop, 
$R_{2}\left(Z_{j}\right)=\left(\beta_{j}-C_{j}\right) \int_{Z_{j}}^{\infty}\left(\theta-Z_{j}\right) \approx \tilde{\varphi}_{j}(\theta) d \theta$ - average losses due to a deficiency in commodities in the, $j$-shop.

Here: $\quad \varphi_{j}(\theta)=\frac{\varphi_{j}(\theta)}{\int_{0}^{Z_{j}} \varphi_{j}(\theta) d \theta}, \quad \stackrel{\approx}{\varphi_{j}}(\theta)=\frac{\varphi_{j}(\theta)}{\int_{Z_{j}}^{\infty} \varphi_{j}(\theta) d \theta}-$ mentioned

densities of the demand distribution in case of a surplus and a shortage of commodities.

In our opinion, the above-described method of modeling the delivery under the influence of risks is cumbersome and cannot be suitable for transforming its components into a linear dependence.

Let us consider different nonlinear model [18] that suggests the two-level system of choice and making of managerial decisions in integrated wood enterprises under the conditions of uncertainty caused by risk factors where the first level solves traditional problems of planning of a wood enterprise's main technical and economic indicators and the second one includes the estimation of a risk profile through expert methods in order to define a total effect of choice of an economic activity strategy. As an optimality criterion this model suggests total income indicator (GM) corrected for the influence of uncertainty and risk factors specified by experts. An intermediate indicator in the course of making of managerial decisions is gross margin (EM) that represents a value of revenues through selling a batch of wood raw materials:

$$
E M_{i}=V_{i} \cdot\left(P_{j} \cdot E C_{i}-S_{i}-T C_{i}+\Delta T_{i}-G C_{i}\right)
$$

where:

$\mathrm{Vi}$ - volume of a planned batch of commodities in $\mathrm{m3}$;

$P j$.ECi - planned revenues from selling $1 \mathrm{~m} 3$ of forest products in national currency (price of 1 $\mathrm{m} 3$ of forest products in foreign currency, ECi - average weighted monthly exchange rate);

$\mathrm{Si}$ - production cost (transfer price) of $1 \mathrm{~m} 3$ of forest products in national currency;

TCi - transport and customs costs of $1 \mathrm{~m} 3$ of forest products in national currency;

$\Delta T i$ - difference between taxes paid to the budget and those compensated from the budget from $1 \mathrm{~m} 3$ of forest products in national currency;

$\mathrm{GCi}$ - general business and commercial expenses attributable to $1 \mathrm{~m} 3$ of forest products in national currency.

A final indicator of the two-level system of choice and making of managerial decisions is gross income corrected for the influence of uncertainty and risk factors defined in an expert way. The formula that expresses this dependence is as follows:

$$
G M_{i}=\left(W_{L}+B_{i}+M_{i}+G_{i}\right) \cdot\left(V_{i} \cdot\left(P_{j} \cdot E C_{i}-S_{i}-T C_{i}+\Delta T_{i}-G C_{i}\right)\right)
$$

The degree of influence of each of the factors on the functional reflects a weight coefficient $g$ determined by a group of experts. According to the influence of the factors on the indicator and the value of the indicator of economic margin (EM) we calculate a total indicator of gross revenues $(G M)$ in respect of each of the product batches and choose the implementation of that economic solution where gross 
revenues corrected for the influence of uncertainty and risk factors take on maximum value [18]. We deem it promising to develop a dynamic model of the transport-technological process of delivery of wood raw materials corrected for uncertainty factors.

The works by I.A. Borodinova and L.A. Saraev [19] show that the solution of a similar problem is reduced to the determination of supply and demand probability coefficients in every production and consumption point; in our opinion, the introduction of the specified consumption and production coefficients under the uncertainty of input parameters into the mathematical model of the transporttechnological process of delivery of wood raw materials is an integral part of this modeling.

Research results. The analysis results of scientific works in the field of solving practical problems connected with wood transport logistics identify such problems as the need to take into account the risk factors by assessing the parameters of mathematical dependencies in the wood transport logistics and the inadequacy of linearly modeled problems in wood transport logistics. The developed by us mathematical model, based on principles of logistics, according to the abovementioned material includes only the main risk factors which are defined by us and have the greatest impact on the wood transport system.

Therefore, the logistics-mathematical model developed by us includes only main factors that influence the process of delivery of wood raw materials according to the risk profile prepared by us. The developed model is of dynamic nature. The choice of an optimal traffic flow structure is defined as a problem of minimizing the $F^{\mathrm{cm}}$ functional:

$$
F^{c m}=F(t)+£(t) \rightarrow \min
$$

where:

$F(t)$ - final functional at time point $t$;

$£(t)$ - effect of financial losses (risk profile) at time point $t$.

$$
£(t)=B(t)+G(t)+W(t)
$$

where:

$B(t)$ - shadowy economic relations in the wood industry and inflation that influences a production cost of (shipped) manufactured products at time point $t$;

$G(t)$ - activities of legislative and monopolistic organizations at time point $t$;

$W(t)$ - resource factor at time point $t$.

The functional $F$ is defined by a total value of subfunctionals $F_{1}, F_{2}$ and $F 3$ representing costs related to the delivery of wood raw materials.

$$
F_{1}=\sum_{i=1}^{m} \sum_{j=1}^{n}\left[C_{i}(t) \cdot\left(1 \pm g_{b}(t)+C_{i j}^{T P}(t) \cdot\left(1 \pm g_{G}(t)\right)\right] \cdot X_{i j}(t) \times\left(1-g_{w}(t)\right)\right.
$$

where:

$C_{i}(t)$ - selling price of $1 \mathrm{~m}^{3}$ forest product at the supplier, rub., at time point $t$;

$C_{i j}^{T P}$ - transportation costs per product unit, rub., at time point $t$;

$i$ - production point, $i=1,2, \ldots, m$;

$j$ - consumption point (dealer, wholesale intermediate seller, $j=1,2, \ldots n$;

$X_{i j}(t)$ - scope of delivery by the $i$-supplier to the $j$-consumer, $m^{3}$ at time point $t$; 
$g_{w}(t)$ - coefficient of assessment of the influence of the resource factor on the volume of (shipped) manufactured products and the influence of a risk of short delivery or of delivery of low-quality products at time point $t$;

$g_{b}(t)$ - coefficient of assessment of the influence of the factor of shadowy economic relations and the influence of inflation on a production cost of (shipped) manufactured products at time point $t$;

$g_{G}(t)$ - coefficient of assessment of the influence of the legislative and monopolistic factor on transportation costs at time point $t$.

Coefficients $g(t)$ specified in expression (10) are defined by the method of expert assessment of forestry specialists; these coefficients show the degree of influence of this or that uncertainty factor on the size of total costs while delivering wood raw materials from the manufacturer to the end user [18].

$$
F_{2}=\sum_{i=1}^{m} \sum_{j=1}^{n} C_{i}^{*}(t) \cdot\left(1 \pm g_{b}(t)\right) \cdot U_{i}(t) \cdot\left(1-g_{w}(t)\right)
$$

where:

$C_{i}^{*}(t)$ - storage costs per product unit at the $i$-supplier, rub., at time point $t$; $U_{i}(t)$ - volume of the supplier's stock, $m^{3}$, at time point $t$.

$$
F_{3}=\sum_{i=1}^{m} \sum_{j=1}^{n} C_{j}^{* *}(t) \cdot X_{i j}^{*}(t) \cdot\left(1-g_{w}(t)\right)
$$

where:

$C_{j}^{* *}(t)$ - short delivery losses per product unit, rub., at time point $t$;

$X_{i j}^{*}(t)$ - short-delivered quantity, $m^{3}$, at time point $t$.

With the constraints of:

(1) The static balance of the supplier and the consumer's volumes:

$$
\sum_{i=1}^{m} a_{i}(t) \cdot \mathrm{K}_{\text {пр }}^{\mathrm{H}}=\sum_{j=1}^{n} b_{j}(t) \cdot \mathrm{K}_{\text {спр }}^{\mathrm{H}}
$$

where:

$a_{i}(t)$ - scope of supply, $m^{3}$, at time point $t$;

$\mathrm{K}_{\text {пр }}^{\mathrm{H}}$ - coefficient of the supply unbalance, \%;

$\mathrm{K}_{\text {спр }}^{\mathrm{H}}$ - coefficient of the demand unbalance, \%;

$b_{j}(t)$ - size of consumption, $m^{3}$, at time point $t$.

$$
\mathrm{K}_{\text {спр }}^{\mathrm{H}}=\frac{Q_{\phi}}{Q_{n л}} \cdot 100 \%
$$

where:

$\mathrm{K}_{\text {cпр }}^{\mathrm{H}}$ - coefficient of the demand unbalance in the j-consumption point;

$Q_{\phi}$ - average actual size of consumption in the j-point for several periods;

$Q_{п л}$ - average planned size of consumption in the j-point for several periods. 


$$
\mathrm{K}_{\text {пр }}^{\mathrm{H}}=\frac{Q_{\phi}}{Q_{n л}} \cdot 100 \%
$$

where:

$\mathrm{K}_{\text {пр }}^{\mathrm{H}}$ - coefficient of the supply unbalance in the i-production point;

$Q_{\phi}$ - average actual volume of production in the i-point for several periods;

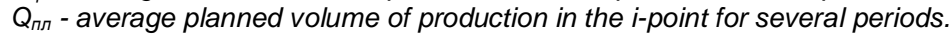

(2) The natural non-negativeness of freght flows and stocks:

$$
\begin{gathered}
X_{i j}(t) \geq 0, i=1,2, \ldots, m, j=1,2, \ldots, n \\
U_{j}(t) \geq 0, j=1, \ldots, n
\end{gathered}
$$

(3) The dynamic link of suppliers and consumers:

$$
X_{i j}^{\prime}(t)=X_{i j}^{\prime \prime}\left(t+t_{i j}\right) \cdot\left(1-g_{w}\right), \mathrm{i}=1,2, \ldots \mathrm{m} ; \mathrm{j}=1,2, \ldots \mathrm{n} ; \mathrm{t}=0,1, \ldots \mathrm{T}
$$

where:

$X_{i}(t)$ - delivered quantity, at time point $t, m^{3}$;

$X_{i j}^{\prime \prime}$ - arrived quantity, at time point $\left(t+t_{i j}\right), m^{3}$;

$t_{i j}$ - standard time of delivery, days.

(4) The movement of consumers and suppliers' stocks:

$$
U_{i}(t+1) \cdot\left(1-g_{w}(t)\right)=U_{i}(t) \cdot\left(1-g_{w}(t)\right)+\sum_{i=1}^{m} X_{i}(t) \cdot\left(1-g_{w}(t)\right)-b_{j}(t) \cdot\left(1-g_{w}(t)\right)
$$

where:

$X_{i}(t)$ - volume of raw materials arrived to the supplier's warehouse, $\mathrm{m}^{3}$, at time point $t$;

$a_{i}(t)$ - total of the supplier's volume, production capacity, at time point $t$;

$U_{i}(t)$ - volume of raw materials arrived to the supplier's warehouse, i.e. accumulation at time point $t$.

(5) The dynamic balance of production and consumption:

$$
\sum_{t=1}^{T} \sum_{i=1}^{m} a_{i}(t) \cdot\left(1-g_{w}(t)\right)=\sum_{t=1}^{t+t_{i j}} \sum_{j=1}^{n} b_{j}(t) \cdot\left(1-g_{w}(t)\right)
$$

where:

$t_{i j}-$ standard time of delivery.

Conclusion. The represented structure of dynamic transportation problem considers the effect of several risk factors ((6) - (18)) on the purpose of rational delivery distribution, shows the priorities for the least expensive items of consumption and takes the costs of shipping to market with the least cost of storage into account. This principle of delivery planning is offered to ensure the application of a logistics approach for the effective functioning of the wood transport system. 


\section{References:}

1. Bavbel', E. I. \& Lyshchik, P. A. 2009 Lesnoy zhurnal [Forestry Journal] vol 4 pp 82-88.

2. Borisov, G. A. \& Kukin, V. D. 2009 Lesnoy zhurnal [Forestry Journal] vol 1 pp 60-65.

3. Bolotov, O. V., El'deshteyn, Yu. M., Bolotova, A. S., Mokhirev, A. P. \& Goryaeva, E. V. 2005 Osnovy rascheta i planirovaniya ustoychivogo upravleniya lesopol'zovaniem [Basics of calculating and planning sustainable forest management] Krasnoyarsk: SibGTU, p 183.

4. Gromov, I. A. \& Tyurin, N. A. 2017 Izvestiya Sankt-Peterburgskoy lesotekhnicheskoy akademii [News of the Saint Petersburg State Forest Technical Academy] vol 219 pp 133-143.

5. Elderstein, Yu. M. 2003 Modeling and optimization of production processes in the forest and woodworking industry Krasnoyarsk: SibGTU p 104.

6. Kovalev, R. N. \& Gurov, S. V. (1996). Planning of transport systems of forest enterprises in a multi-purpose forest management Ekaterinburg: Ural. State Forestry Academy.

7. Kovyazin, V. F. \& Romanchikov, A. Yu. (2018). Notes of the Mining Institute, (Vol. 229, pp. 98104). St Petersburg.

8. Kovyazin, V. F. \& Romanchikov, A. Yu. (2015). Notes of the Mining Institute, (Vol. 216, pp. 232237). St Petersburg.

9. Livitin, A. V. (2006). Introduction to The Design and Analysis of Aigorithms, (pp. 349-353). Moscow: Vil'yams.

10. Sokolov, V. A. (2014). Cibirskiy lesnoy zhurnal [Siberian Forest Journal], (pp. 14-24). Krasnoyarsk.

11. Chernykh, R. A. (2011). Khvoynye boreal'noy zony [Conifers of the boreal area], (pp. 130-133). Pavlov N. I. (Ed.). Krasnoyarsk: SibGTU.

12. Chernykh, R. A. \& Bolotov, O. V. (2009). Vodnye resursy regiona, ikh okhrana i ratsional'noe ispol'zovanie [Water resources of the region, their protection and rational use], (pp. 67-68). Bolotov O. V. (Ed.). Krasnoyarsk: SibGTU.

13. Thomas, H. Cormen. (2009). Introduction to Algorithms, (3rd ed). MIT Press.

14. Abdi, E., Majnounian, B., Darwishsefat, A., Mashayekhi, Z. \& Sessions J. (2009). Journal of Forest Science, 55(4), 171-176.

15. Newnham, R. M. (1995). Journal of Forest Engineering, 6(2), 17-26.

16. Gnedash, M. A. (2006). Thesis by Candidate of Technical Sciences. Lipetsk

17. Seraya, O. V. \& Dunaevskaya, O. I. (2011). The Technology of Solution of Undefined Nonlinear Multiindex Transport Problems Information technologies: science, technique, technologies, education, health: Int. Sc.-Pract. Conf., (vol 19). Krakow, Poland.

18. Kobalinsky, M. V. (2006). Thesis by Candidate of Economic Sciences. Krasnoyarsk.

19. Saraev, L. A. \& Borodinova, I. A. (2010) Stokhasticheskaya transportnaya zadacha [A Stochastic Transportation Problem], (7), 81. 


\section{MULTIPLE INPUTS AND MIXED DATA FOR MACHINE LEARNING MODELS}

Kateryna Hurieieva applicant for master degree, Faculty of mathematics Zaporizhzhia National University

UKRAINE

There are several cases in machine learning where using multiple inputs and mixed data for developed models can be necessary. For example, predicting stock data is gaining popularity during last years. Common machine learning models are expected to follow similar architecture: input layer, several internal layers and output layer. But while predicting stock data, one can face the lack of predictability of single closing or opening values usage. Existing of technical analysis indicators allows to gain much more information from time-series representing the stock value.

To improve prediction accuracy of the model, using several datasets based on the original price data and different indicators data would be a great choice. For this purpose certain approach is proposed: by using one layer as concatenation layer, which gets as input a two-dimensional array, where first dimension represents a number of different datasets.

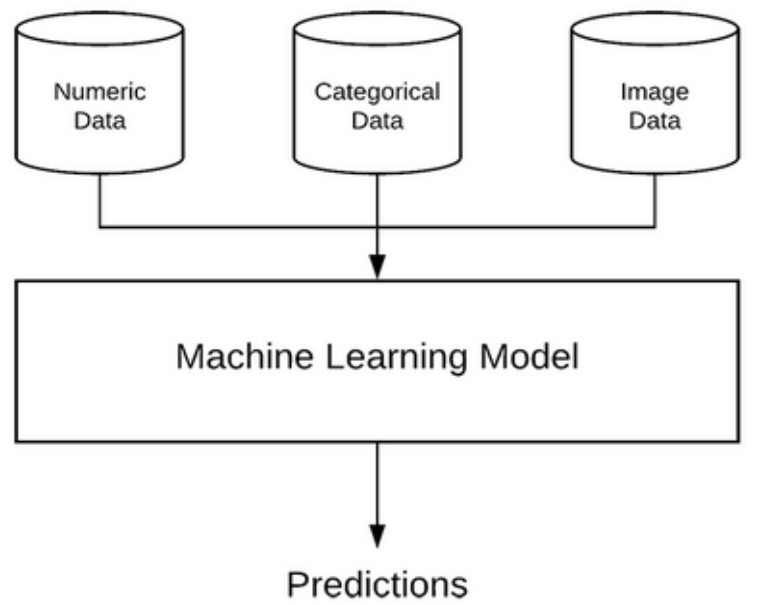

Fig. 1. Representation of proposed approach.

In order to implement suggested approach a Keras library model capable of accepting multiple inputs, including numerical, categorical and image data can be used. Developing machine learning systems capable of handling mixed data and several inputs can be extremely challenging as each data type may require separate preprocessing steps, including scaling, normalization, and feature engineering. Keras is able to handle multiple inputs and even multiple outputs via its functional API. 
The functional API, as opposed to the sequential API, can be used to define much more complex models that are non-sequential, including multi-input models, multi-output models, models than are both multiple input and multiple output.

Several branches of a model can be defined to handle each type of data or input dataset. The branches can then be combined at the end to obtain final prediction.

Proposed approach can be very useful in diverse tasks: from stock prices prediction with several inputs to house prices prediction with images and textual information as inputs.

\section{References:}

1. Keras: Multiple Inputs and Mixed Data. Retrieved from https://ilianweng.github.io/lil$\log / 2017 / 06 / 21 /$ an-overview-of-deep-learning.htm|\#recurrent-neural-network.

2. Dingli, A., Fournier, K. S. (2017). Financial Time Series Forecasting - A Machine Learning Approach. Machine Learning and Applications : An International Journal (MLAIJ), Vol .4, (1/2/3).

DOI 10.36074/25.10.2019.v1.10

\section{USING OF «UTAS SYSTEM»DATA AT RISK-ORIENTED APPROACH TO THE OCCUPATIONAL SAFETY SYSTEM ORGANIZATION ON MINES OF UKRAINE}

\section{Vira Griadushcha \\ Ph.D. (Engineering), Senior Lecturer Bila Tserkva Institute for Continuing Professional Education, Public higher education institution "University of Management Education" of the National Academy of Pedagogical Sciences of Ukraine}

UKRAINE

The Association Agreement between Ukraine and the EU, ratified in 2014, determined its course towards European integration. In accordance with the Program of Ukraine's Integration into the European Union [1], European integration is the main and invariable foreign policy priority of Ukraine, and further development and deepening of relations between Ukraine and the EU is carried out on the principles of political association and economic integration, which in turn provides for the implementation of reforms by the country, both legal and social.

One of the most important directions of European integration is the harmonization of legislation in accordance with EU standards. Labor development in accordance with EU requirements is of particular interest to Ukraine, because this is the way to improve the work of Ukrainian enterprises.

In the framework of the Government's Action Plan for the Implementation of the European Social Charter (revised) for 2015-2019, Ukraine is considering ratification of eight ILO conventions related to occupational safety standards in industry, including coal [2]. Ukraine is considering ratification of the Convention on the Promotional Framework for Occupational Safety and Health Convention, 2006 (No. 
187), which defines the obligations of employers carry out work to identify, evaluate, eliminate or minimize risks.

In accordance with the Protocol of the round table "Reforming the system of management of safework taking into account international experience" in the framework of the 16th International Forum "Fuel and Energy Complex of Ukraine: Present and Future" [3] the state of legislative and regulatory support of the fuel and energy complex on occupational safety and industrial safety issues, its compliance with Ukraine's international legal obligations in the field of European integration, as well as problems, prospects and adaptation were examined.

It was emphasized that the organization of the occupational safety management system should take into account international occupational safety management standards based on risk management OHSAS - 18001, ISO 9001.

With regard to enterprises, specific industries and jobs in international practice and from the experience of a number of domestic organizations, the most common method of expert assessment is risk determination based on hazard category categories matrices and the level (degree) of severity of possible consequences.

The basis of technical risk is the risk of equipment breakdown, accident or catastrophe due to technical factors.

Earlier [4], the author of this article proved that one of the most important characteristics of the technical condition of dynamic equipment, in addition to operating parameters, is vibration intensity, which carries information about defects and malfunctions of equipment elements, various kinds of imbalances, misalignments, clearances, tensions, etc.

The unified telecommunication automated dispatch control system and automated control of mining machines and technological complexes (the UTAS system), used in the coal industry of Ukraine, is equipped in some mines with sensors that monitor vibration parameters in real time.

We propose to use these data, both for predicting the vibration parameters themselves, and for determining the probability distribution of equipment uptime. And on the basis of the results obtained, to assess the possible consequences of failures, determine the category of risks and their relationship with the threat to human health and life, the danger to the environment, as well as economic costs, which manifest in various forms (simple, compensation for injuries, property damage, damage to the environment, etc.).

Previously, experimental calculations were carried out for main ventilation mine fans [4]. However, in our opinion, this approach can be applied to different types of dynamic mine equipment.

\section{References:}

1. Baza danykh «Zakonodavstvo Ukrainy». (2010). The Program of Ukraine's Integration into the European Union. Retrieved from http://zakon.rada.gov.ua/laws/show/n0001100-00. [in Ukrainian].

2. Information on the International Labour Office (2018). Okhorona pratsi i pozhezhna bezpeka. Retrieved from http://oppb.com.ua/articles/informaciya-pro-mizhnarodnu-organizaciyu-praci. [in Ukrainian].

3. Reforming the system of management of safework taking into account international experience (2018). Palyv.-enerh. kompleks Ukrainy: sohodennia ta maibutnie: XVI mizhn. forum, (6-8 
lystopada 2018r.). Retrieved from http://mpe.kmu.gov.ua/minugol/control/uk/doccatalog/list?currDir=205780. [in Ukrainian].

4. Griadushcha, V. V. (2018). Use of equipment reliability indicators for the risk management of the occupational system of coal-mining enterprises. Journal of Donetsk Mining Institute: Civil Security, 2(43), 69-79. Retrieved from http://jdmi.donntu.edu.ua/wpcontent/uploads/2019/02/Griadushcha_JDMI_2_2018.pdf [in Ukrainian].

\title{
ВИКОРИСТАННЯ DOUBLE VPN - AHOHIMНICTЬ TA БЕЗПЕКА В IHTEPHETI
}

\author{
Шкребтій Андрій Володимирович \\ здобувач освітнього ступеня доктора філософії \\ Черкаський Державний Технологічний Університет \\ Науковий керівник: Миронець Ірина Валеріївна \\ канд. техн. наук, доцент, доцент кафедри \\ інформаційної безпеки та комп'ютерної інженерії \\ Черкаський Державний Технологічний Університет
} УKPAÏHA

Ринок VPN з кожним роком стає все ширшим і більш потрібним для загалу. Підґрунтям для цього $€$ багато причин: від хакерів, які полюють за конфіденційною інформацією, до корпорацій і держав, які стежать за активністю користувачів і обмежують доступ до контенту. Останнім часом кількість причин для використання VPN (Virtual Private Network - віртуальна приватна мережа) стрімко збільшується.

Для чого може використовуватись VPN:

Конфріденційність $і$ анонімність в мережі. Уряд вивчає нашу поведінку в інтернеті, корпорації профілюють користувачів для цільової реклами, захисники авторських прав стежать за торрент-трафіком, тому захист за допомогою VPN стала природним рішенням.

Безпека. Ті, хто використовують загальнодоступні точки доступу $\mathrm{Wi}-\mathrm{Fi}$, покладаються на шифрування, щоб приховати конфіденційні дані від хакерів. Життя активістів і журналістів при репресіях залежать від нього. Підприємства використовують VPN для захисту цінної корпоративної інформації.

Розваги і інфрормація. Компанія GlobalWeblndex в дослідженні 2018 року визначила, що 57\% мобільних користувачів VPN-сервісів використовують мережу для перегляду розважального контенту. VPN також застосовують для обходу блокування соціальних мереж, веб-сайтів і сервісів, наприклад: отримати доступ до гео-обмеженого контенту (на даний час на території України діє указ президента №133/2017 «Про застосування персональних спеціальних економічних та інших обмежувальних заходів (санкцій)»).

Для того, щоб від чогось захищатися, потрібно чітко розуміти модель загроз. Тобто фракт підключення умовного IP-адреси 1.1.1.1 до адреси 2.2.2.2 в певний час доби записується. Маючи доступ до такої інформації в масштабах провайдера, міста або країни, досить просто встановити, хто саме ховається 
за VPN. Щоб підвищити рівень приватності при використанні VPN, необхідно розділити точку підключення і точку виходу в інтернет на рівні IP. Для цього вирішено використовувати технологію Double VPN (подвійний VPN).

Під назвою «подвійний» VPN часто розуміють різні речі, але майже завжди це означає рознесені територіально або на мережевому рівні вузли підключення і виходу в інтернет. Іноді це просто маркетинговий трюк VPNпровайдерів, який не означає абсолютно нічого, такі послуги можуть називатися «потрійним» і «четверним» VPN.

На практиці існує декілька робочих схем реалізації «подвійного» VPN:

1. VPN між серверами.

У такому режимі клієнт встановлює VPN-підключення до тільки першого сервера. На першому сервері налаштований тунель до другого, і весь трафік від клієнта йде до другого сервера, і т.д. Проміжних серверів може бути декілька. При цьому тунель між серверами може бути встановлений по будьякому іншому протоколу, відмінному від протоколу, за яким підключений клієнт, наприклад IPsec, або взагалі без шифрування, на кшталт GRE aбo IPIP. У такому режимі всі проміжні сервера може бути видно в трасуванні маршруту. Перевірити, як саме підключені між собою проміжні сервера на стороні клієнта немає можливості, тому можна тільки довіряти провайдеру.

На всьому шляху проходження трафріку мінімальний MTU (Maximum Transmission Unit) залишається рівним значенню самого першого тунелю, і кожен проміжний сервер має доступ до розшифрувати трафріку клієнта це зображено на рис. 1.

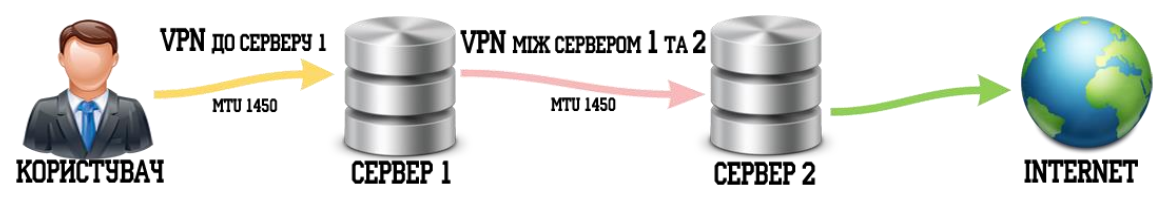

Рис. 1. Схема VPN між серверами

2. VPN через проксі.

Теж досить поширений спосіб. Часто використовується для маскування VPN-трафріку під інший протокол, наприклад в Китаї. Такий спосіб зручніше ланцюжка з проксі, тому що за допомогою VPN легко маршрутизувати весь системний трафрік в тунель. Існують також інструменти для перехоплювання системних викликів програм і перенаправлення їх в проксі: ProxyCap, Proxifier, але вони менш стабільні, так як іноді пропускають запити і вони йдуть повз проксі або працюють некоректно з деякими програмами. В цьому режимі проксі-сервер не видно в трасуванні маршруту, що зображено на рис. 2:

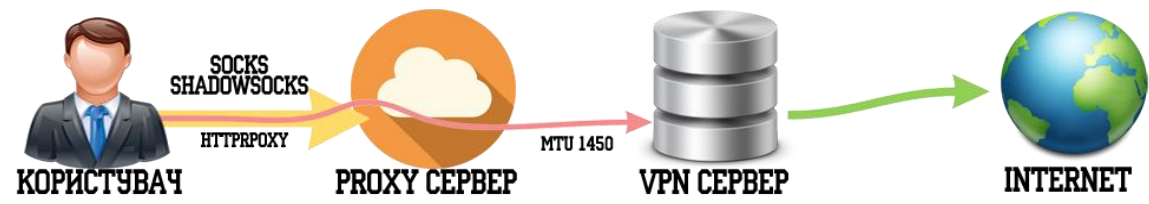

Pис. 2. Схема VPN через проксі 
3. VPN всередині VPN.

Самий параноїдальний і повільний спосіб: всі тунелі піднімаються на стороні клієнта, при цьому кожен всередині іншого. Такий спосіб вимагає правильно підібраних налаштувань маршрутів на стороні клієнта і запуску всіх VPN-клієнтів в потрібному порядку. Це погано позначається на затримках і продуктивності, зате проміжні сервера не мають доступу до відкритого трафріку клієнта. Всі накладні витрати по інкапсуляції підсумовуються, і максимальний розмір пакета (MTU), доступний в результаті клієнтові, зменшується в залежності від числа тунелів. Проміжні сервери не видно в трасуванні маршрутів (рис. 3).

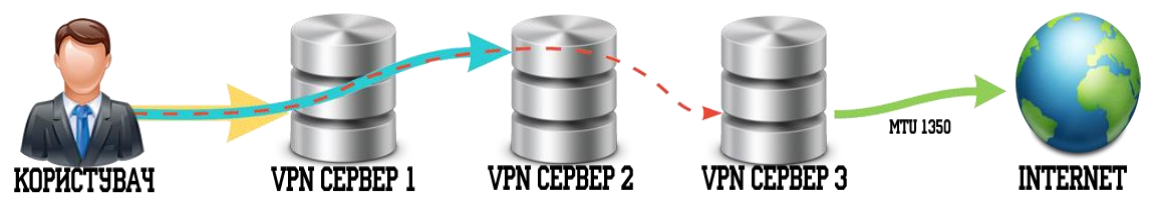

Рис. 2. Схема VPN всередині VPN

Найлегший спосіб налаштувати VPN з розділеними точками входу і виходу - підключити кілька IP-адрес на один віртуальний сервер. Цей спосіб дозволяє отримати максимальну швидкість і мінімальні затримки, так як по суті трафрік термінується на одному сервері. Для використання Double VPN можна скористатись вже готовими комерційними рішеннями типу: VPN Monster|NORD VPN|Anonymox VPN тощо, або розгорнути та налаштувати свій персональний сервер.

Висновки. Отже, для чого потрібний Double VPN:

- Підвищується рівень шифрування даних. Всі ваші дані захищені додатковим рівнем шифрування. Тому хакерам їх удвічі важче розшифрувати.

- Підвищується рівень безпеки. У з'єднаннях використовується суміш протоколів UDP і TCP, що підвищує рівень безпеки ваших дій в Інтернеті.

- Підвищується Захист IP-адреси, оскільки фактична IP-адреса була підмінена першим сервером VPN, другий сервер не має про вас ніякої інфрормації.

- Повна конфріденційність. Ніхто не може бачити ваш кінцевий пункт призначення в Інтернеті, навіть ваш інтернет-провайдер. Він може знати тільки той факт, що ви використовуєте VPN.

\section{Список використаних джерел:}

1. Наливайко, А. (2019). Ton-10 VPN-сервисов. Вилучено із: https://www.antimalware.ru/analytics/Market_Analysis/top-10-vpn.

2. WebGears Services Limited, CyberYozh security group. (2018). Курс по анонимности и безопасности в сети. Москва.

3. Жовнер П. (2019). Двойной VPN в один клик. Как легко разделить IP-адрес точки входа и выхода. Вилучено із https://habr.com/ru/company/vdsina/blog/469879/. 


\section{ВИКОРИСТАННЯ МАСЛЯНКИ ДЛЯ ВИРОБНИЦТВА ОЗДОРОВЧОГО НАПОЮ 3 КОМБІНОВАНИМ СКЛАДОМ СИРОВИНИ}

\section{Стеценко Наталія Олександрівна}

кандидат хімічних наук, доцент кафедри технології оздоровчих продуктів Національний університет харчових технологій УКРАЇНА

На сучасному етапі розвитку суспільства люди повсякчас відчувають дію значної кількості зовнішніх чинників, які негативно впливають на стан їх здоров'я: погана екологія, низький рівень фізичної активності, стреси, високі психологічні навантаження, неправильне харчування тощо. Для підтримання здоров'я необхідно активізувати захисні сили організму, нормалізувати його фрункції та обмін речовин, що дозволяє забезпечити правильне, здорове харчування [1].

Одним 3 пріоритетних напрямів розвитку молочної промисловості $€$ комплексне і раціональне використання вторинної молочної сировини, що може бути реалізовано за рахунок розширення асортименту продуктів, які виробляються з використанням сироватки і маслянки. Економічно доцільним та обґрунтованим $€$ шлях використання такої сировини для виробництва кисломолочних та ферментованих напоїв. Для підвищення харчової i біологічної цінності продуктів використовується їх збагачення фрункціональними інгредієнтами, у тому числі пробіотичною мікрофрлорою, яка відіграє важливу роль у підтриманні здоров'я людини, що обумовлено її участю в активізації імунних процесів, пригніченні активності хвороботворної мікрофрлори, стимуляції процесів травлення, продукуванні вітамінів.

Маслянка заслуговує особливої уваги як основа для створення напоїв оздоровчого призначення. Маслянка - це плазма вершків, вторинна сировина, яку отримують під час їх перероблення на масло. Основними та найціннішими компонентами маслянки є білки, вуглеводи (лактоза), молочний жир, а також небілкові азотисті сполуки, мінеральні солі, ферменти, органічні кислоти та майже всі сполуки незбираного молока. У її складі присутній комплекс біологічно активних речовин, що мають мінімальну енергетичну цінність. Порівняльний аналіз хімічного складу маслянки та незбираного молока свідчить про доцільність перероблення вторинної сировини (табл. 1) [2].

Таблиця 1

\section{Порівняння складу маслянки та незбираного молока}

\begin{tabular}{|c|c|c|}
\hline \multirow{2}{*}{ Назва нутрієнту } & \multicolumn{2}{|c|}{ Масова частка, \% } \\
\cline { 2 - 3 } & Маслянка & незбиране молоко \\
\hline Сухі речовини & $8,3 \ldots 9,5$ & 12,3 \\
\hline Білок & $2,9 \ldots 3,2$ & 3,2 \\
\hline Жир & $0,4 \ldots 0,7$ & 3,6 \\
\hline Лактоза & $4,7 \ldots 4,8$ & 4,8 \\
\hline Мінеральні речовини & $0,6 \ldots 0,7$ & 0,7 \\
\hline
\end{tabular}


Жир маслянки істотно відрізняється від жиру вершкового масла. Якщо в останньому переважають олеїнова, пальмітинова, міристинова та стеаринова жирні кислоти, то у жирі маслянки містяться біологічні цінні лінолева, ліноленова та арахідонова жирні кислоти, які мають антисклеротичні властивості та відносяться до незамінних харчових речовин.

Лактоза маслянки нормалізує процеси бродіння у шлунково-кишковому тракті. Мінеральні речовини незбираного молока майже повністю переходять у маслянку. Вона має багатий вітамінний склад, у якому переважають вітаміни групи В, біотин та холін, який має антисклеротичні властивості (табл. 2) [2].

Таблиця 2

Вміст вітамінів у маслянці, мг\%

\begin{tabular}{|c|c|c|c|c|c|c|c|c|c|}
\hline Сировина & $\mathrm{B}_{1}$ & $\mathrm{~B}_{2}$ & $\mathrm{~B}_{6}$ & $\mathrm{~B}_{12}$ & $\mathrm{C}$ & $\mathrm{A}$ & $\mathrm{E}$ & $\mathrm{H}$ & Холін \\
\hline $\begin{array}{c}\text { Незбиране } \\
\text { молоко }\end{array}$ & 0,45 & 1,50 & 0,33 & 4,00 & 1,50 & 0,25 & 0,85 & 56,0 & 313,0 \\
\hline Маслянка & 0,36 & 2,00 & 1,60 & 4,20 & 2,70 & 0,08 & 0,55 & 50,0 & 416,0 \\
\hline
\end{tabular}

Багатий біохімічний склад маслянки обумовлює доцільність ії застосування для створення харчових продуктів оздоровчого призначення. Як молочна основа може використовуватись суміш знежиреного молока і маслянки. Такий вибір обумовлений наступними перевагами: перероблення і раціональне використання вторинної молочної сировини, низький вміст жиру та дієтичні властивості, економічна доцільність. Експериментально встановлено, що найкращу консистенцію має продукт, у якому співвідношення знежиреного молока і маслянки становить 1:2. Також можна використовувати такий технологічний прийом, коли маслянка буде вноситися на етапі нормалізації молока. Тоді маслянка повинна мати кислотність не вище як $19^{\circ} \mathrm{T}$, а густину не нижче як $1027 \mathrm{kr} / \mathrm{M}^{3}$.

Запропоновано при виробництві кисломолочного напою використовувати стабілізатор молочної основи - низькометоксильований пектин. Такий прийом дозволяє покращити структурно-механічні властивості кисломолочних продуктів і сприяє поліпшенню життєдіяльності лактобактерій. Пектин виконує роль не тільки стабілізатора структури, а й функціонального інгредієнту, який має здатність зв'язувати та виводити з організму іони важких металів та радіонукліди. Оптимальна кількість пектину становить $0,4 \%$ до маси сировини. Його розчиняють у невеликій кількості молока та вносять після нормалізації суміші. Наступні етапи виробництва кисломолочного напою відбуваються за традиційною технологією.

\section{Список використаних джерел:}

1. Стеценко, H. О. (2019). Функціональні харчові продукти у забезпеченні здоров'я людини. Die Relevanz und die Neuheit der modernen wissenschaftlichen Studien: der Sammlung wissenschaftlicher Arbeiten "А'ОГО ¿" zu den Materialien der internationalen wissenschaftlichpraktischen Konferenz, (B.3, ss. 56-59). August 23, 2019, Wien, Republik Österreich: NGO «Europäische Wissenschaftsplattform».

2. Грек, О. В. Поліщук, Г. Є. \& Онопрійчук О. О. (2011). Технологія продуктів зі знежиреного молока, молочної сироватки і маслянки. Київ: НУХТ. 


\title{
ІДЕНТИФІКАЦІЯ КОРИСТУВАЧІВ МОБІЛЬНИХ ПРИСТРОЇВ НА ОСНОВІ ДИНАМІКИ НАБОРУ ПАРОЛЬНОЇ ФРАЗИ
}

\author{
Мазниченко Наталя Іванівна \\ старший викладач кафедри криміналістики \\ Національний юридичний університет імені Ярослава Мудрого
}

УКРАИНА

Мобільні телефони знайшли важливе місце в сучасному суспільстві, які на сьогоднішній день використовують сотні мільйонів людей у всьому світі. Останнім часом мобільні пристрої все більше використовуються в фінансових додатках, для здійснення банківських операцій, покупок, платежів та інших дій, що потребують впевненості в надійності захисних механізмів для користувача. Також в мобільних пристроях може зберігатись конфіденційна та важлива інформація, що потребує обмеження в доступі для сторонніх користувачів. Як наслідок, ідентифрікація користувачів для мобільних пристроїв стала важливою проблемою. Саме ідентифікація розмежовує доступ до мобільного телефону між авторизованим користувачем (власником) та зловмисником.

Сучасні системи ідентифікації користувачів цифрових пристроїв засновані на використанні в якості унікального ідентифрікатора наступних характеристик: парольних, біометричних, апаратних (або електронних) [1]. Серед всіх ідентифікаційних ознак користувачів в сучасних мобільних пристроях використовуються або паролі та PIN-коди або деякі біометричні ознаки. Серед біометричних характеристик можуть бути використані відбиток пальця, зображення обличчя, голос, тобто, такі ознаки, для отримання яких непотрібні додаткові пристрої. Але все ж таки більшість мобільних пристроїв використовують слабкі механізми ідентифрікації, засновані на паролі та PINкоді. Якщо враховувати таку ситуацію, доцільно дослідити потенціал інших технологій з метою підвищення надійності парольного захисту.

Останніми роками для досягнення цієї мети деякими авторами було запропоновано разом 3 паролем використовувати таку біометричну характеристику, як динаміка натискання клавіш під час набору пароля, яка аналізує ритм набору тексту користувачем. Слід зауважити, що більшість авторів наукових праць свої дослідження сконцентрували на використанні такої ідентифікаційної ознаки для комп'ютерних систем. Виникає питання, чи можливо використовувати динаміку натискання клавіш як механізм безпеки для мобільних пристроїв? Проаналізуємо можливість, доцільність, ефективність використання такої ідентифікаційної характеристики, як динаміка набору символів під час введення парольної фрази для підвищення надійності захисту мобільних пристроїв.

Використання динаміки натискання клавіш в мобільних пристроях має певні особливості в порівнянні зі звичайними клавіатурами, що використовуються в персональних комп'ютерах:

- Використання меншою кількості пальців (зазвичай використовуються тільки два великих пальця або один вказівний палець).

- У комп'ютерних системах зі зміною клавіатури шаблон введення 
користувача може відрізнятися. Але це не так в мобільних пристроях 3 сенсорним екраном.

Будь-яка біометрична ідентифікація не визначає користувача 3 абсолютною точністю. 3 паролем все просто: він або еквівалентний еталону, або ні. Системи біометричної ідентифікації впізнають користувача з певною вірогідністю, тому усі системи біометричної ідентифікації оцінюються по наступним характеристикам:

- FRR (False Reject Rate) або помилка першого роду - вірогідність помилкових відмов зареєстрованому користувачеві;

- FAR (False Accept Rate) або помилка другого роду - це вірогідність допуску незареєстрованого користувача (помилковий пропуск «чужого»);

- EER (Equal Error Rates) - рівна імовірність помилок першого і другого роду.

Всі системи розпізнавання такої характеристики як динаміка набору парольної фрази передбачають два режими роботи: навчання і безпосередньо ідентифікації.

На етапі навчання користувач вводить парольну фразу (іноді вимагається повторювати цю дію декілька разів). При цьому розраховуються і запам'ятовуються еталонні характеристики цього користувача (створюється еталонний шаблон користувача). На етапі ідентифікації користувач, що претендує на доступ, вводить парольну фразу, для якої також розраховуються ті ж самі характеристики, які порівнюються з еталонними.

Під час введення визначається, яка клавіша була натиснута, час утримання клавіші, час, коли вона була відпущена. I так для кожної клавіші парольної фрази. Далі ці часові характеристики використовуються створення особистого шаблону користувача.

Для реалізації процесу розпізнавання користувача в сучасних системах ідентифікації використовують класифікатор, заснований на одному 3 наступних математичних підходів [2]: статистичні методи, нейронні мережі, методи розпізнавання образів, імовірнісні, комбіновані. В результаті порівняння шаблонів користувачеві або надається доступ до мобільного пристрою або відмовляється в доступі.

Дослідження публікацій стосовно використання динаміки введення парольної фрази для мобільних пристроїв не надають чіткої відповіді на питання, який з методів дає кращі показники розпізнавання особи користувача. Річ у тому, що більшість наукових робіт по зазначеній темі, $є$ незалежними дослідженнями, кожне з яких засноване на певній кількості зразків, зібраних 3 унікальних наборів користувачів. Дослідники збирали ці зразки за допомогою різних методів і широко варіювалися в вимірюваних даних, кількості вхідних даних, необхідних для навчання системи і ідентифікації користувачів, кількості випробовуваних і різноманітності цих випробовуваних, умовах тестування, мобільних пристроях. Така неоднорідність ускладнює порівняння різних досліджень. Якщо додати до цієї складності різноманітність підходів до класифікації користувачів і застосування цих технологій в різних областях, завдання стає ще складнішим.

Існує величезний розкид у кількості зібраних авторами даних для проведення досліджень і демонстрації ефективності їх систем. Слід зазначити, 
що більшість авторів обмежуються невеликою кількістю випробовуваних, що не сприяє впевненості в достовірності результатів. Також важливим чинником в системах ідентифрікації за динамікою натискання клавіш $€$ вибір парольної фрази, її довжина. I тут також різняться думки авторів з приводу оптимальної довжини парольної фрази, що знову ж таки ускладнює процес порівняння різних підходів. 3 приводу кількості і інформативності параметрів динаміки натискання клавіш, що використовуються при побудові системи ідентифікації, думки різних авторів також різняться. Слід зазначити, що більшість авторів використовують тільки дві часові характеристики: натиснення (утримання) клавіші і інтервали між натисненнями двох послідовних клавіш. Деякі автори вважають, що сила натискання пальця під час набору символу діє як кращий індикатор для ідентифікації користувачів в порівнянні з часом утримання клавіші і паузою між натисканнями клавіш. А деякі автори стверджують, що поєднання часових характеристик з силою натискання дає кращі результати в порівнянні з їх розглядом окремо.

Порівняти та оцінити результати досліджень щодо систем ідентифікації користувачів мобільних пристроїв за динамікою набору парольної фрази за різними показниками можна за таблицями, представленими в роботі [3]. Для різних досліджень можна дізнатись: які інформативні параметри використовувались; методи, що використовувались для класифікації користувачів; різновид парольної фррази (PIN-код, довільні символи, тільки цифрри); довжина парольної фррази; отримані значення EER, FAR, FRR; зазначена точність ідентифікації; кількість користувачів, що приймали участь у експериментах; мобільні пристрої, що використовувались у експериментах; інформацію о виправленнях при наборі; зібрана кількість зразків. Така статистична інформація дуже корисна користувачеві для того, щоб було легше визначитися з вибором.

Враховуючи тенденції розвитку сучасних мобільних пристроїв можна впевнено стверджувати, що технологія ідентифрікації користувачів мобільних пристроїв за ритмом введення парольної фрази має великій потенціал і буде запитаною завдяки наступним перевагам: простота та зручність використання завдяки звичним для користувача процедурам введення паролю; відсутність потреби в придбанні додаткових пристроїв завдяки використанням вбудованої клавіатури. Але огляд та аналіз досліджень за цією технологією дозволяє зробити висновки, що існує ряд проблем, що потребують вирішення. Відсутність загального набору стандартів для збору даних ускладнює процес оцінювання і зіставлення окремих незалежних методів. В даному випадку існує необхідність в спільному використанні наборів вхідних даних дослідниками для використання у власних системах ідентифікації. Було б доцільно розробити стандарт, з яким кожен дослідник може порівняти свої результати. Жодне дослідження не порівнювало і не аналізувало відмінності в типах набору користувачів в різних ситуаціях, наприклад, коли користувач сидить, стоїть, йде або лежить. Також необхідно провести дослідження по оптимальній довжині пароля, типу і мінімальній кількості необхідних зразків, щоб якнайшвидше створити профіль користувача.

Саме від вирішення зазначених проблем буде залежати популярність та затребуваність даної технології у користувачів мобільних пристроїв. 


\title{
Список використаних джерел:
}

1. Кошева, Н. А., Мазниченко, Н. І. (2013). Ідентифікація користувачів інформаційнокомп'ютерних систем: аналіз і прогнозування підходів. Системи обробки інфрормації, (6), 215-223.

2. Salil P. Banerjee, Damon L. Woodard. (2012). Biometric Authentication and Identification using Keystroke Dynamics: A Survey. Journal of Pattern Recognition Research, (7), 116-139.

3. Baljit Singh Saini, Navdeep Kaur, Kamaljit Singh Bhatia. (2016). Keystroke Dynamics for Mobile Phones: A Survey. Indian Journal of Science and Technology, Vol 9(6), 1-8. Вилучено із http://www.indjst.org/index.php/indjst/article/view/82084

\section{ІНФОРМАЦІЙНІ ТЕХНОЛОГІЇ СИСТЕМИ ПІДТРИМКИ ПРИЙНЯТТЯ РІШЕНЬ В ПРОЦЕСАХ УПРАВЛІННЯ ВЗАЄМОВІДНОСИНАМИ ВИДАВНИЧО-ПОЛІГРАФІЧНИХ ПІДПРИЄМСТВ ЗІ СТЕЙКХОЛДЕРАМИ}

\begin{abstract}
Андрющенко Тетяна Юріївна
Харківський національний економічний університет ім. С. Кузнеця

УKPAÏHA
\end{abstract}

Системи підтримки прийняття рішень, призначені спеціально для надання сприяння у вирішенні завдань пошуку, аналізу і вибору кращих з можливих варіантів, слід розглядати як програмні засоби та інформаційно-аналітичні технології. Суб'єкт, який приймає рішення, повинен забезпечуватися не тільки інфрормаційної, а й технологічною підтримкою. Технологія комп'ютерної підтримки є складною структурою, що вимагає для свого створення системного підходу. Одним з найважливіших принципів системного підходу, що застосовується при створенні СППР, є принцип ієрархічної декомпозиції і багатокритеріального аналізу [1].

Проведений аналіз автоматизованих систем управління відношеннями, дозволив дійти висновків, що задача прийняття рішень в діяльності видавничополіграфрічних виробництв не вирішуються в повній мірі. До безсумнівних переваг сучасних автоматизованих систем управління необхідно віднести можливість модиффікації й розширення встановлених модулів з урахуванням специфріки конкретного підприємства. Гнучкість систем забезпечується настроюванням локальних баз даних для кожного без винятку процесу будьто калькуляція замовлень, планування виробництва чи то виробничий облік у цехах, матеріально-технічне постачання, облік готової продукції чи фінансовий облік.

В роботі В. С. Слапік [2] інформаційна складова СППР розглядається 3 точки зору зовнішнього світу. Інформаційна складова СППР з управління паартнерськими відносинами на видавничо-поліграфрічному підприємстві представлена на рис. 1. 


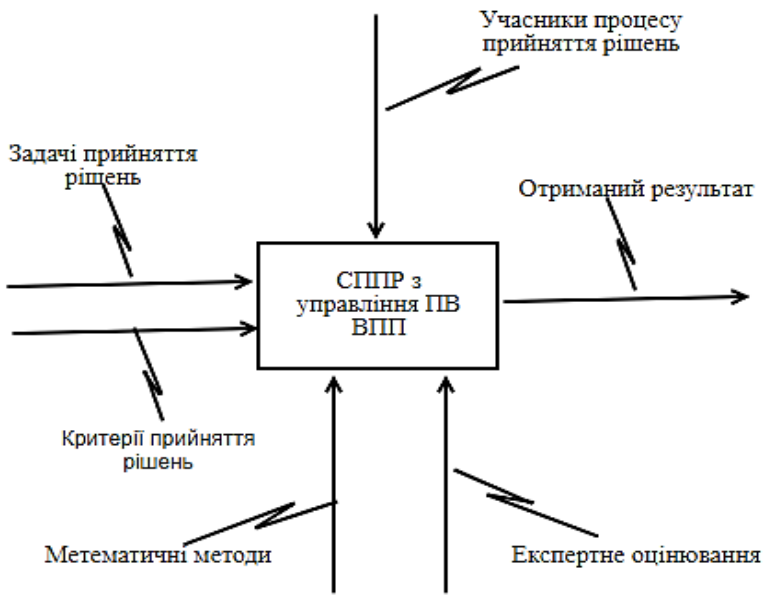

\section{Рис. 1. Інформаційна складова СППР з управління партнерськими відносинами на видавничо-поліграфічних підприємствах} Допрацьовано автором на основі [2]

Під час впровадження СППР з управління партнерськими відносинами на видавничо-поліграффічних підприємствах усі дані про підприємство вводяться на початковому етапі. В подальшому, дані можуть додаватися в процесі роботи.

Збір та введення інформації може відбуватися як шляхом вводу 3 клавіатури та масивом інформації з супутніх підрозділів, відділ менеджерів може надавати відомості про партнерів та клієнтів, відділ кадрів - дані про співробітників, завідуючий складом (складські робітники) - інформацію про відвантаження готової продукції та запаси матеріалів і т.д.

При використанні окремих модулей СППР з управління партнерськими відносинами сторонніми суб'єктами (партнерами) дані можуть вводитися партнером самостійно, наприклад, оформлення замовлення.

Важливим напрямком практичної реалізації рефлексивного підходу $\epsilon$ використання економіко-математичного моделювання рефлексивних процесів в економіці. Так, рефлексивна модель економічної системи, крім опису природних характеристик системи, повинна відображати і область поведінки суб'єктів системи, зовнішніх систем, а також їх здатність усвідомлення самих себе і інших суб'єктів, включаючи і тих, які роблять спроби керувати ними.

Рефлексивні моделі дозволяють розширити наукове уявлення про суб'єктах економічних систем, що підвищує адекватність моделювання. Це пов'язано в першу чергу з тим, що на відміну від традиційних, природнонаукових моделей, моделі рефлексивні не обмежуються відображенням матеріальної реальності економічної системи, в них також закладена система багатогранних відображень суб'єктами цієї системи [3].

Проведений аналіз автоматизованих систем управління відношеннями дозволив сфрормувати інформаційну складову СППР 3 управління партнерськими відносинами видавночо-поліграфрічного підприємства. В подальшому необхідно розробити математичний апарат для реалізації СППР 
3 управління партнерськими відносинами видавночо-поліграфрічного підприємства.

\title{
Список використаних джерел:
}

1. Слапик, В. С. (2019) Информационные системы поддержки принятия решений в управлении IT-проектами. Вилучено з http://elib.bsu.by/handle/123456789/52171.

2. Токарев, К. Е., Кузьмин, В. А. \& Шатырко, Д. В. (2015). Разработка инструментальных средств СППР в сфере эколого-экономической безопасности. Современная экономика: проблемы и решения, 5 (65), 31-41.

3. Лепа Р. М. \& Мадих, А. А. (2011). Перспективи використання рефлексивного підходу в економіці. Економіка: реалії часу. (1), 17-20. Вилучено 3 http://economics.opu.ua/files/archive/2011/n1.html.

\section{МІНЕРАЛЬНИЙ СКЛАД ЕКСТРАКТІВ ЧАЮ РІЗНОГО ПОХОДЖЕННЯ}

\author{
Соколова Ольга Миколаївна \\ асистент кафедри технології оздоровчих продуктів \\ Національний університет харчових технологій
}

УКРӒ̈НA

Чай - один із найбільш розповсюджених тонізуючих напоїв у світі. Він має приємні смакові властивості, добре втамовує спрагу, чинить позитивний вплив на діяльність багатьох органів та систем організму людини. Його отримують шляхом висушування молодих пагонів вічнозеленого чайного куща.

Чай містить як органічні сполуки (дубильні речовини, поліфеноли тощо), так і неорганічні з'єднання, які в основному представлені оксидами калію, фосфору, кальцію та магнію [1].

В Україні, окрім зеленого та чорного чаю, широко використовують настої 3 м'яти, меліси, ехінацеї, тобто трав'яні та ягідні чаї, а також фіточаї оздоровчого призначення. Елітні сорти чаю містять більше калію та фосфрору. У чаях низької якості вищим є вміст натрію та кальцію [2].

Відомо, що мінеральні речовини не мають енергетичної цінності, але беруть участь у найважливіших обмінних процесах організму, зокрема водносольовому та кислото-лужному обмінах. Тому були проведені дослідження по визначенню вмісту натрію, калію та кальцію, як найбільш розповсюджених макроелементів, у зразках Карпатського чаю та фіточаю доктора Селезньова, що представляє собою полікомпонентні рослинні збори, які рекомендують для профілактики тих чи інших захворювань.

Як контрольні зразки використовували традиційні чорні та зелені чаї без добавок та ароматизаторів виробництва Шрі Ланка, а також чай Ліптон. Вміст мінеральних речовин визначали методом полуменевої фотометрії. Екстракти отримували при температурі $100^{\circ} \mathrm{C}$ протягом 10 хвилин, співвідношення твердої та рідкої фази становило 1:100.

В усіх досліджених зразках спостерігався найбільший вміст калію - від 700 до 1700 мг/100 г. Цей елемент нормалізує тиск та поліпшує роботу нирок. 
Серед Карпатських чаїв найбільшим вмістом калію відрізнявся чай з м'яти, а найменшим - чай з малини. Значно менше виявлено натрію - від 25 до 150 мг/100 г. Вміст кальцію коливався від 120 до 800 мг/100 г.

Було досліджено вплив тривалості екстрагування на кількісний вміст мінеральних речовин у чаях. Встановлено, що при збільшенні часу настоювання від 10 до 30 хвилин кількість калію у всіх екстрактах різко зростала у 1,5-2 рази. Кількість натрію практично не залежала від тривалості екстрагування. Була помічена тенденція до зменшення вмісту кальцію у всіх екстрактах, що, можливо, пояснюється його зв'язуванням у нерозчинні комплекси з дубильними речовинами.

Кислото-лужний баланс організму людини значною мірою залежить від кислотності та складу харчових продуктів та напоїв, які споживає людина. Тому в отриманих екстрактах визначали $\mathrm{pH}$ та загальну кислотність потенціометричним методом. Встановлено, що $\mathrm{pH}$ екстрактів чорного, зеленого чаю, фріточаю доктора Селезньова та м'ятного Карпатського чаю знаходиться у межах 7 одиниць, тобто має нейтральну реакцію. Карпатські чаї лісові ягоди, шипшина, суниця, малина, мультифрукт мали кислу реакцію середовища, pH чаїв було у межах від 2,8 до 3,1 одиниць. Тому людям, що мають шлунково-кишкові захворювання, споживати такий чай краще після консультації лікаря у визначених ним кількостях.

\section{Список використаних джерел:}

1. Рубанка, К. В., Терлецкая, В. А. \& Зинченко, И. Н. (2014). Исследование физико-химических свойств водных экстактов чая. Научни трудове на Университет по хранителни технологии, (LXI, I), 63-68.

2. Рубанка, К. В., Терлецька, В. А., Зінченко, І. М. \& Біла Г. М. (2014). Дослідження процесу екстракції макроелементів при виробництві продуктів на основі чаю зеленого. Наукові праці HYXT, (20, 1), 228-233.

DOI 10.36074/25.10.2019.v1.11

\section{МОДЕЛЬ ОЦІНКИ НАДІЙНОСТІ ПРОГРАМНОГО ЗАБЕЗПЕЧЕННЯ ІНФОРМАЦІЙНО-УПРАВЛЯЮЧИХ СИСТЕМ СПЕЦІАЛЬНОГО ПРИЗНАЧЕННЯ}

НАУКОВО-ДОСЛІДНА ГРУПА:

Ляшенко Ігор Олександрович

кандидат військових наук, доцент кафедри військової підготовки Київський Національний економічний університет ім. Вадима Гетьмана

Войтко Олександр Володимирович кандидат військових наук, начальник науково-дослідної лабораторії Національний університет оборони України ім. І.Черняховського

Шевченко Дмитро Георгійович кандидат військових наук, професор кафедри зв'язку та автоматизованих систем управління Національний університет оборони України ім. І.Черняховського 
Маланчук Марина Федорівна кандидат економічних наук, начальник науково-дослідної лабораторії проблем оборонного менеджменту Національний університет оборони України ім. І.Черняховського

Мулявка Андрій Степанович старший науковий співробітник науково-дослідного відділу автоматизації процесів управління особовим складом Національний університет оборони України ім. І.Черняховського

Прима Микола Васильович старший науковий співробітник науково-дослідного відділу автоматизації процесів управління інфрраструктурою військових об'єктів Національний університет оборони Украйни ім. І.Черняховського УКРАЇНA

Функціонування інфоораційно-управляючих систем спеціального призначення (ІУССП), призначених для автоматизації управління у всіх сфрерах діяльності [1, 2], відбувається в постійній взаємодії з зовнішнім середовищем. При цьому масштаб такої взаємодії провокує різноманітні конфрлікти, які істотно впливають на досягнення загальносистемної мети. Такі (інформаційні) конфлікти приводять до руйнування інформаційних ресурсів, порушення інформаційних процесів, i, як наслідок, до зриву виконання системних і прикладних функцій $[3,4]$.

Все це зумовлює наявність в ІУССП механізмів, які повинні забезпечувати нову якість - здатність збереження та/або відновлення даних функцій в умовах різного роду несприятливих дій [5].

Дану якість назвемо функціональною стійкістю (ФС) ІУССП. ФС $є$ інтегральною властивістю, яка інтегрує в себе надійність, живучість та безпеку. Відповідно оцінка показників ФС, що необхідна для порівняння різних варіантів синтезу ІУССП, являється складним науково-практичним завданням. Ще складнішим є пошук найкращого варіанту, при якому досягаються оптимальні показники ФС при деяких обмеженнях. У цьому напрямі отримано ряд науковопрактичних результатів.

Основна частина. Досвід створення і застосування ІУССП протягом останніх десятиліть виявив безліч ситуацій, при яких збої та відмови їх функціонування були обумовлені дефектами програмного забезпечення i супроводжувалися великим збитком. Наслідком помилок в програмному забезпеченні автоматичного управління стала втрата чисельних як вітчизняних, так і зарубіжних супутників, відмови та катастрофи в складних адміністративних, банківських та технологічних ІУССП.

В результаті близько двадцяти років тому з'явилися перші узагальнюючі праці, в яких були сформульовані концепція та основні положення теорії надійності програмного забезпечення. Саме в той час були закладені основи методології і технології створення надійних комплексів програм, але існуючі методи та підходи рішення даної проблеми не передбачали, що пояснювалося унікальністю кожної програмної системи. 
Сучасне програмне забезпечення використовує при роботі величезний об'єм даних, що надходять через стандартні модулі та функції. Тому виявити всі зв'язки та шляхи обробки інформації навіть для достатньо нескладної програми, практично неможливо.

Як правило, оцінка надійності ПО базується на теорії надійності технічних систем, в рамках якої розроблено значну кількість математичних моделей та методів [6-8]. Зазвичай розглядаються моделі, які згруповано за наступними ознаками:

- моделі, які пов'язані з теорією надійності технічних засобів;

- моделі, які не базуються на теорії надійності апаратури;

- моделі, які дозволяють оцінити програмне забезпечення з урахуванням його складності.

Як показники надійності програмного забезпечення використовуються:

- імовірність працездатного стану програмного забезпечення на заданому інтервалі часу;

- середній час прояву помилки;

- інтенсивність помилок.

Пропонується розглянути та проаналізувати можливість застосування в цьому напрямку моделі оцінки надійності програмних засобів на прикладі динамічних дискретних моделей Шумана та Муса. В даних моделях передбачається спочатку проведення тестування (можливо за кілька етапів), а при виникненні відмов здійснюється пошук та виправлення усіх помилок, завдяки яким трапились відмови програмного забезпечення.

В моделі Шумана тестування здійснюється поетапно, кожен етап при цьому являє собою виконання програми з набору тестових даних. Помилки, які виявлено в ході тестування, проходять реєстрацію, але не виправляються. По закінченню чергового етапу виправляються усі виявлені помилки, корегуються тестові набори та проводиться наступний етап тестування.

Передбачається, що при корегуванні нові помилки не вносяться, інтенсивність виявлення помилок пропорційна кількості помилок, що залишились.

Нехай проводиться усього $\kappa$ етапів тестування. Позначимо час проведення кожного етапу через $t_{1}, \ldots, t_{k}$, а кількість, виявлених на кожному етапі, через $m_{1}, \ldots, m_{k}$.

Нехай $T=t_{1}+\ldots t_{k}$ - загальний час тестування; $n=m_{1}+\ldots m_{k}$ - загальна кількість виявлених та виправлених в ході тестування помилок; $n_{i}=m_{1}+\ldots m_{i}$ - кількість помилок, які виправлено до початку $(i+1)$-го етапу тестування $\left(n_{0}=0\right)$.

Модель Шумана на $i$-му етапі тестування описується функцією надійності

$$
R_{i}(t)=e^{-\lambda_{i} t}
$$

de $\lambda_{i}=\left(N-n_{i-1}\right) C$; 
$N-n_{i-1}$ - кількість помилок на початок $i-$ го етапу;

C - коефіцієнт пропорційності, що дорівнює:

$$
C=\frac{\sum_{i=1}^{k} \frac{m_{i}}{N-n_{i-1}}}{\sum_{i=1}^{k} t_{i}} .
$$

Щоб знайти кількість помилок на початок тестування використовуємо рівняння

$$
\sum_{i=1}^{k} m_{i} \frac{\sum_{i=1}^{k} t_{i}}{\sum_{i=1}^{k} \frac{m_{i}}{N-n_{i-1}}}=\sum_{i=1}^{k}\left(N-n_{i-1}\right) t_{i} \text {. }
$$

При відомих значеннях $k ; t_{1}, t_{2}, \ldots, t_{k} ; m_{0}, m_{1}, \ldots, m_{k}$ можна знайти значення параметрів моделі $N$ та $C$. Після чого визначаються наступні показники:

Кількість помилок в програмному забезпеченні, що залишилась:

$$
N_{\tau}=N-n \text {; }
$$

Функцію надійності програмного забезпечення на кінець тестування

$$
R(t)=e^{-\lambda t},
$$

de $\lambda=(N-n) C$.

Переваги та недоліки моделі.

До переваг відноситься те, що немає необхідності звертатись до інших моделей, що значно скорочує час розрахунку надійності.

До недоліків відносять припущення, що при корегуванні не вносяться нові помилки, що не являється звичайним явищем в реальних програмах. Крім того, в процесі тестування необхідно реєструвати велику кількість даних, які необхідні для розрахунку по формулам моделі.

В моделі Муса надійність програмного забезпечення на етапі експлуатації оцінюється за результатами тестування.

Нехай $T$ - загальний час тестування, $n$ - кількість відмов, що трапились в ході тестування. Тоді загальне напрацювання до відмови після тестування на етапі експлуатації визначається за формулою

$$
\tau=\tau_{0}\left(\frac{C T}{n \tau_{0}}\right),
$$

де $\tau_{0}$ - середнє напрацювання до відмови до початку тестування; 
C - коефіцієнт урахування ущільнення тестового часу в порівнянні з часом реальної експлуатації. Наприклад, якщо одна година тестування відповідає 12 годинам роботи в реальних умовах, то $C=12$.

Параметр $\tau_{0}$ можна оцінити із співвідношення:

$$
\tau_{0}=\frac{1}{N K F},
$$

де $N$ - вихідна кількість помилок в програмному забезпечення;

$K$ - коефіцієнт прояву помилок;

$F$ - середня швидкість виконання одного оператора програми.

Вихідну кількість помилок в програмному забезпечення $N$ можна оцінити за допомогою іншої моделі, за допомогою статистичних даних, отриманих при тестуванні. Коефіцієнт прояву помилок $K$ визначається емпіричним шляхом за однотипними програмами (зазвичай його значення міститься в інтервалі між $1,5 \times 10^{-7}$ та $4 \times 10^{-7}$ ). Середня швидкість виконання одного оператора програми $F$ дорівнює відношенню середньої швидкості виконання програмного забезпечення до кількості команд.

Надійність програмного забезпечення для періоду експлуатації $T$, при напрацюванні часу до відмови $t$, визначається за формулою

$$
R(t)=\exp \left(-\frac{t}{T}\right) \text {. }
$$

Висновки. До переваг запропонованої моделі можна віднести відсутність необхідності фріксувати моменти відмов. У випадку відмови помилки реєструються, а виправляються лише по закінченню етапу тестування.

До недоліків слід віднести те, що для визначення вихідної кількості помилок в програмному забезпечення необхідно вести розрахунки по іншій моделі, що неминуче призведе до додаткових витрат часу.

Програмне забезпечення використовується в різних сферах людської діяльності. Головною вимогою до сучасного ПО $є$ його надійність. Застосування недостатньо надійного ПО може привести до відмови в складних системах (адміністративною, банківською, управління військами та зброєю), що призведе до катастрофічних наслідків для всієї інфраструктури в цілому. Тому так важливо створити методологічну базу для розробки надійного, ефективного та безпечного програмного забезпечення.

\section{Список використаних джерел:}

1. Ляшенко, І. О. (2012). Інформаційна безпека інформаційно-управляючих систем. Матеріали восьмої наукової конференції Харківського університету Повітряних Сил імені Івана Кожедуба, 18-19 квітня 2012 р. Харків, Україна: ун-т Пов. Сил ім. І. Кожедуба.

2. Ляшенко, І. О. (2012). Кібернетична загроза розподіленим інформаційно-управляючим системам спеціального призначення. Матеріали науково-практичної конференції Державного науково-дослідного інституту авіації Національного авіаційного університету, 5-6 липня 2012 р. Київ, Україна: ДНДІА. 
3. Ляшенко, І. О. (2010). Застосування перспективних інформаційних технологій у збройній боротьбі. Труди університету. зб. наук. праць НУОУ, 1(94), 144-150.

4. Яяшенко, І. О. (2010). Кібернетичні операції - майбутня форма збройної боротьби. Збірник наукових праць Хмельницької НАДПС, (53), 37-40.

5. Ляшенко, І. О. (2010). Розрахунок ффункціональної надійності апаратно-програмної складової інформаційно-аналітичних систем інтрамереж Збройних Сил України. Труди університету. зб. наук. праць НУОУ, 3(96), 111-120.

6. Попов, А. М. \& Гуров, С. В. (2006). Основы теории надежности. СПб.: БХВ-Петербург.

7. Липаев, В. В. (1998). Надежность программных средств. М.: СИНТЕГ.

8. Тайер, Т, Липов, М. \& Нельсон, Э. (1981). Надежность программного обеспечения [nер. 3 англ.]. М.: МИР.

\section{НАПІВФАБРИКАТИ ДЛЯ ЗБАГАЧЕННЯ ХАРЧОВИХ ПРОДУКТІВ ДЛЯ ВІЙСЬКОВОСЛУЖБОВЦІВ}

Гойко Ірина Юріївна

канд. техн. наук, доцент, доцент кафедри технології оздоровчих продуктів Національний університет харчових технологій УКРАЇHA

Вступ. Постійне фрізичне та психологічне перенапруження військовослужбовців викликає істотну перебудову метаболічних процесів, що в сукупності ставить їх організм на межу, а іноді за межу функціональних можливостей [1]. Тому великого значення для забезпечення витривалості та високої боєздатності військовослужбовців набуває правильно організоване і повноцінне харчування.

Оптимізація раціону харчування військових шляхом використання спеціалізованих харчових продуктів дозволить покращити функціональний стан і неспецифічну резистентність організму. Правильна організація харчування сприятиме підтриманню працездатності, швидкому відновленню після навантажень, адаптації до екстремальних умов, зміни біологічних ритмів, підтриманню оптимального гідратаційного режиму і мінерального обміну в організмі [1].

Тому метою досліджень $є$ розроблення нових функціональних напівфабрикатів для збагачення харчових продуктів для військовослужбовців.

Матеріали і методи. Аналіз літературних джерел, результати власних досліджень, методологічні підходи.

Результати досліджень. Як основу для напівфабрикатів було обрано молочну сироватку, L-карнітин та бурштинову кислоту.

Сироваткові білки, які є важливим компонентом молочної сироватки, оптимально збалансовані за амінокислотами, особливо сірковмісними цистином, метіоніном, що створює хороші можливості для регенерації білків печінки, гемоглобіну і білків плазми крові. Комплекс вітамінів і ферментів доповнюють феномен біотехнологічної системи молочної сироватки [2].

L-карнітин (L-Carnitine) - вітаміноподібна речовина, яка виводить 3 організму токсичні сполуки, запобігаючи тим самим їх накопичення. При 
підвищених фрізичних навантаженнях, що притаманні військовослужбовцям, Lкарнітин витрачається інтенсивніше, що потребує його додаткового споживання [3].

Однією 3 найцінніших властивостей бурштинової кислоти для людей 3 підвищеними навантаженням (військовослужбовців) $є$ здатність посилювати утилізацію лактату. Завдяки активній участі бурштинової кислоти в підтриманій фрункціональної гіперактивності центральної нервової системи, її застосовують при стресі, підвищених фрізичних і розумових навантаженнях, зниженні захисних сил організму в період і після важких захворювань, при дії на організм токсичних речовин і радіації [4].

В якості збагачувачів було обрано ягоди та овочі, розповсюджені на території України, а саме цукровий буряк, моркву, гарбуз, чорноплідну горобину (аронію) та імбир.

Рослинну сировину використовували у вигляді порошків. Сушіння проводили конвективним способом при невисоких температурах сушильного агенту (повітря) $-35 \pm 5^{\circ} \mathrm{C}$, швидкість руху теплоносія $4,5 \mathrm{~m} / \mathrm{c}$. Процес сушіння завершували при досягненні продуктом рівноважної вологості 8,0 - 10,0\%, що практично виключає можливість розвитку більшості мікроорганізмів.

Для отримання напівфабрикатів фрільтровану молочну сироватку пастеризують, охолоджують, перемішують, висушують, охолоджують та подрібнюють у порошок. Суху молочну сироватку змішували із рецептурними інгредієнтами до досягнення однорідності. Даний спосіб сухого змішування, завдяки варіюванню виду та дози збагачувачів, дає змогу розширювати та удосконалювати асортимент напівфабрикатів.

Для напівфрабрикату № 1, в якості збагачувачів використовували цукровий буряк, моркву та гарбуз, для напівфабрикату № 2 - чорноплідну горобину та імбир.

За органолептичною оцінкою напівфабрикати мають молочно-солодкий смак з присмаком наповнювачів, приємний, властивий наповнювачам, колір.

Для оптимального співвідношення компонентів розраховано харчову та енергетичну цінність напівфабрикатів.

Встановлено, що при споживанні 100 г на добу в раціоні харчування осіб чоловічої статі 4 групи інтенсивності праці (військовослужбовців) добова потреба в харчових волокнах забезпечується на 10,24 \%, білку - на 36,94 $45,58 \%$, в $\beta$-каротині на $14,4-41 \%$, в вітаміні С, який як і $\beta$-каротин є потужним антиоксидантом, на 21,66 \%. Це дозволяє віднести отримані напівфабрикати до категорії функціональних.

Висновки. Розроблено рецептури напівфабрикатів для збагачення харчових продуктів для військовослужбовців. Проведено органолептичну оцінку отриманих композицій та розраховано їх енергетичну цінність, яка складає 316,80 та 337,75 Ккал, відповідно, що дозволяють збагатити харчовий вітаміном C та $\beta$-каротином.

\section{Список використаних джерел:}

1. Українець, А. І., Стеценко, Н. О. \& Сімахіна Г. О. (2017). Розроблення спеціалізованих харчових продуктів для екстремальних умов життєдіяльності. Харчова промисловість, (21), 67-73.

2. Храмцов, А. Г. (2011). Феномен молочной сыворотки. СПб.: Профессия. 
3. Яковлева, Л. В., Безчаснюк, Е. М., Улесов, А. В., Шаповал, О. Н., Хомякова, Л. Г. \& Зборовская, Т. В. (2011). L-карнитин: свойства, препараты, медицинское применение. Укр. журн. клін. та лаб. мед., 6(2), 17-24.

4. Heinen, A., Camara A. \& Aldakkak M. (2007). Mitochondrial $\mathrm{Ca}^{2+}$ - induced $\mathrm{K}^{+}$influx increases respiration and enhances ROS production while maintaining membrane potential. American Physiology and Cell Physiology, 292(1), 148-156.

\title{
ОБҐРУНТУВАННЯ ШЛЯХІВ ЕКОНОМІЇ ПАЛИВНО- МАСТИЛЬНИХ МАТЕРІАЛІВ БЮДЖЕТНОЇ УСТАНОВИ
}

\author{
Коренчук Карина Вікторівна \\ здобувач освітнього рівня «бакалавр» \\ Національна академія Державної прикордонної служби \\ України імені Б. Хмельницького
}

Науковий керівник: Чмир Віктор Миколайович

кандидат технічних наук, доцент кафедри

транспортних засобів та спеціальної техніки

Національна академія Державної прикордонної служби

Украӥни імені Б. Хмельницького

УКРАЇ̈А

Нафта $€$ основною сировиною для виробництва паливно-мастильних матеріалів і відноситься до не відновлювальних видів сировини, запаси якої в надрах землі обмежені. Старі нафтородовища поступово вичерпуються, а нові відкриваються, як правило, у важкодоступних, малообжитих районах або на морському шельфрі, тому витрати на добування нафти зростають.

Все це призводить до того, що темпи росту видобування нафти в останні роки значно знижуються в багатих країнах світу і в Україні зокрема.

Виникає невідповідність між все зростаючими потребами нафтопродуктів для різного виду техніки i можливостями задоволення цих потреб нафтопереробною промисловістю. Для подолання такої невідповідності необхідні значні зусилля як виробників нафртопродуктів, так і їх споживачів. [1].

Тому, питання економного використання паливно-мастильних матеріалів в бюджетних установах варто розглядати не як зниження їх витрат, а значно ширше - як визначення основних напрямків енергозберігаючої політики. В цьому і полягає актуальність дослідження.

Отже, обґрунтуємо нижче деякі шляхи з економії паливно-мастильних матеріалів в бюджетній установі.

Втрат на складі і при заправці за рахунок протікань і відпливів можна практично уникнути цілком при технічній справності устаткування і зразковому порядку. Втрат від випаровування бензинів цілком запобігти не вдається, але значно скоротити їх можна. Цьому сприяє заправка закритим струменем, справні прокладки і клапани, герметичні насоси, засувки, рукави, роздавальні крани тощо. 
$104 \bullet$ Scientific discoveries: projects, strategies and development $\bullet$ Volume 1

Витрата палива й масел залежить від організації перевезень, на які впливає:

- ступінь використання корисної вантажності автомобіля;

- ступінь використання пробігу автомобілів.

Ступінь використання вантажопідйомності автомобіля характеризується відношенням маси перевезеного вантажу до номінальної вантажопідйомності автомобіля, тобто коефіцієнтом використання вантажопідйомності - ү.

Зі збільшенням у зменшується питома витрата палива на одиницю транспортної роботи (тонно-кілометр), при повному використанні вантажопідйомності, коли $\mathrm{y}=1$, питома вага палива буде мінімальною. Збільшення коефіцієнта використання вантажопідйомності на $1 \%$ знижує питому витрату палива на 1,6 \% [1].

Витрати палива на одиницю транспортної роботи можуть бути скорочені при підвищенні коефіцієнта використання пробігу - $\beta$, що характеризується відношенням пробігу автомобіля з вантажем до загального пробігу.

Збільшення коефіцієнта використання пробігу на 1 \% знижує питому витрату палива на 1,3 \%. Для збільшення коефіцієнта $\beta$, автомобілі завантажують вантажем при прямуванні не тільки у прямому, але й у зворотному напрямку, складають маршрути прямування так, щоб були мінімальними нульові пробіги.

Значним резервом скорочення витрати палив і масел у транспортній роботі $€$ застосування причепів. При організації перевезення вантажів на автопоїздах досягається скорочення палива на $25-30$ \% у порівнянні 3 одиночними автомобілями.

Використання палива й масел, що не відповідають конструктивним особливостям транспортного засобу, неминуче викликає його перевитрату.

Негативні результати дає використання палива, що не відповідає кліматичним і сезонним умовам. Якість палива й масла чинить взаємний вплив на їхню витрату.

Застосування невідповідних трансмісійних масел і масел для двигуна викликає збільшення витрати не тільки самих масел, але й палива.

Витрата бензину підвищується при заправці агрегатів вантажних автомобілів у зимових умовах трансмісійними маслами, що не відповідають даним кліматичним умовам (на 3-6 \% - при русі за містом по дорозі 3 ассральтобетонним покриттям; на 8-12 \% - при русі в міських умовах), у порівнянні 3 витратою бензину в тих же автомобілях, але з агрегатами, заправленими відповідними зимовими трансмісійними маслами. [2]

На витрату палива впливає також масло у двигуні, що має завищену в'язкість. Масло з неприпустимо низькою в'язкістю, поряд 3 іншими негативними явищами, витрачається у більших кількостях, ніж масло із нормальною в'язкістю.

Пластичні мастила, що мають недостатню межу міцності, ефективну в'язкість і низьку температуру краплепадіння, також витрачаються у великих кількостях, тому що вони легко плавляться і швидко витікають із вузлів тертя.

Істотний вплив на витрату всіх паливних і мастильних матеріалів має технічний стан транспортних засобів. Навіть дрібні несправності транспортних засобів, що не мають прямого відношення до витрати палива, можуть стати 
причиною його перевитрати. Підвищена витрата палива, відбувається за таких причин [2]:

- несправність або неправильне регулювання карбюратора, паливного насосу, насоса-форсунки;

- підтікання палива з приладів і трубопроводів систем живлення;

- неправильне регулювання системи запалювання;

- зниження компресії в циліндрах;

- незадовільний стан зчеплення, механізмів силової передачі і ходової частини автомобіля;

- несправність рульового керування.

Витрата палива транспортними засобами може змінюватися в залежності від його технічного стану і сягати до 20-30 \% від нормативної витрати, а при значних несправностях і більше.

Великий вплив на витрату паливно-мастильних матеріалів чинить стан дороги, пора року і доби тощо. Проте витрата паливно-мастильних матеріалів залежить ще й від індивідуальних якостей водія, його кваліфікації. Це й уміння і бажання водія заощаджувати паливо, володіння навичками ощадливого водіння, вибір швидкості руху, правильне використання накату, підтримка найбільш вигідного теплового режиму двигуна й ін.

Таким чином, з наведеного вище основного матеріалу дослідження можна надати наступні практичні рекомендації з шляхів економії паливно-мастильних матеріалів в бюджетних установах, а саме:

- запобігання і скорочення втрат на складі і при заправці транспортних засобів;

- якісна організація транспортного процесу;

- відповідність застосовуваних паливно-мастильних матеріалів конструктивним особливостям транспортних засобів й умовам експлуатації;

- експлуатація технічно справних транспортних засобів;

- уміле водіння транспортних засобів.

\section{Список використаних джерел:}

1. Bendera, I. M., Duhanets, V. I., Kyzyma, M. I., Kovalyshyn, S. Y. \& Kuvachov, V. P. (2016). Palyvno-mastylni ta inshi ekspluatatsini materialy. Kamianets-Podilskyi: FOP Sysyn Ya.I. [in Ukrainian].

2. Yarmolenko. O. Ye. (2000). Avtomobilni ekspluatatsiini materialy. Khmelnytskyi: NAPVU. [in Ukrainian]. 


\title{
ОБҐРУНТУВАННЯ ШЛЯХІВ РАЦІОНАЛІЗАЦІЇ МАТЕРІАЛЬНО- ТЕХНІЧНИХ ВИТРАТ НА ЗАБЕЗПЕЧЕННЯ ЕКСПЛУАТАЦІЇ ТРАНСПОРТНИХ ЗАСОБІВ
}

\author{
Чмир Віктор Миколайович \\ кандидат технічних наук, доцент, доцент кафедри технологічної та \\ професійної освіти і декоративного мистецтва \\ Хмельницький національний університет \\ УКРӒ̈HA
}

Одним із актуальних питань забезпечення високої технічної готовності транспортних засобів (ТЗ) автотранспортних підприємств є обґрунтування шляхів раціоналізації матеріально - технічних витрат на забезпечення їх експлуатації за результатами оцінки техніко-технологічних показників їх застосування.

Досвід роботи структур технічного забезпечення свідчить про те, що доля техніко-технологічних затрат коштів у їх сукупних операційних витратах на систему технічного забезпечення займає $36 . .44 \%$, і має тенденцію до збільшення за умови росту цін на пальне, запчастини і експлуатаційні матеріали [1]. За техніко-технологічними показниками оцінюється ефективність організації використання Т3, а певна частина з них показує продуктивність використання рухомого складу в цілому.

Методологія визначення техніко-технологічних показників ефективності використання ТЗ полягає у наступному.

Коефріцієнт використання рухомого складу характеризує ступінь застосування Т3 безпосередньо у перевезеннях вантажів та персоналу. Він визначається, як відношення кількості одиниць рухомого складу, які щоденно використовувались в рейсах протягом певного періоду до наявної кількості призначених для перевезень ТЗ на підприємстві за цей же проміжок часу.

Високим рівнем величини даного коефіцієнту для установи з 50 і більше одиницями рухомого складу вважається $0,94 \ldots 0,96$. Коли його значення менше, то це свідчить про недосконалість системи технічного обслуговування і ремонту рухомого складу на підприємстві.

Коефріцієнт вікового стану рухомого складу і - того типу визначається, як відношення рекомендованого середньозваженого віку даного типу ТЗ до фрактичного їх середнього віку на даний період. Коефіцієнт показує ступінь оновлення рухомого складу новими зразками. Якщо він більше 1,15 , це свідчить про тенденцію зменшення вікової різниці серед зразків даного типу, що загрожує перспективою одночасності виходу їх в капітальний ремонт та напрацювання до списання. Коли він менше 0,85, це загрожує тенденцією старіння даного типу рухомого складу, що призведе надалі до суттєвого росту витрат на усунення відмов та проведення поточних ремонтів. Дослідженнями встановлено, середньозважений вік вантажних автомобілів повинен бути в межах $8,2-8,4$ роки, автобусів $7,3-7,8$ роки, легкових автомобілів $6.4-6,7$ роки. 
Коефіцієнт використання вантажопідйомності парку рухомого складу, призначеного для перевезень, розраховується як відношення фактичної маси перевезених вантажів автомобілями, що були у рейсі у даному періоді до сумарної вантажопідйомності вантажних автомобілів і причепів підприємства. Він залежить від якості роботи технічної служби установи (правильного підбору типу автомобіля, розміру перевезеної партії вантажу, нарощування бортів для легких вантажів). В залежності від повноти завантаження автомобіля та характеру вантажу даний коефіцієнт доцільно мати в межах 0,65 - 1,0. При значенні менше 0,65 суттєво зростає собівартість перевезень.

Коефіцієнт використання пробігу рухомого складу характеризує рівень організації процесу перевезень зі ступінню ефективності використання моторесурсу ТЗ. Він визначається як відношення сумарного пробігу рухомого складу з вантажем до їх загального пробігу у даному періоді. Мінімальне значення становить 0,5, що свідчить про рух автомобіля у зворотному напрямку з пустим кузовом (салоном). Збільшення його величини досягається розширенням централізованих доставок вантажів по кільцевим маршрутам 3 вивезенням на зворотному шляху інших матеріальних цінностей, що підлягають перевезенню на суміжні підрозділи. Зі збільшенням величини коефіцієнту використання пробігу знижуються сукупні операційні витрати, зростає продуктивність автомобілів без збільшення їх пробігу. Раціональна величина даного коефріцієнту - 0,72 - 0,86 [2].

Таким чином, за наданими методичними підходами оцінки значень технікотехнологічних показників застосування транспортних засобів можуть бути визначені раціональні характеристики комплектування підприємств як по кількості, так і по конкретним зразкам Т3, а також доцільні річні їх напрацювання для конкретних умов експлуатації. Поточне діагностування наведених показників забезпечує коректне встановлення раціональних меж загального напрацювання, доцільних термінів та обсягів ремонту основних зразків ТЗ з мінімізацією витрат коштів при цьому.

\section{Список використаних джерел:}

1. Kyrylenko, V. A., Artiushyn, L. M. \& Kalenyk, M. M. (2013). Ekonomika ekspluatatsii transportnykh zasobiv biudzhetnykh ustanov sylovykh ministerstv ta vidomstv Ukrainy. Khmelnytskyi: DPSU [in Ukrainian].

2. Pro vvedennia $v$ diiu Norm vytrat na tekhnichne obsluhovuvannia i potochnyi remont po bazovym markam avtomobiliv [Nakaz Ministra transportu Ukrainy], №7/1-4-1071 vid 15.12.1995. (1995). Kyiv: Transport [in Ukrainian]. 


\section{ОРГАНІЗАЦІЯ НАВЧАННЯ УЧНІВ 3 ВИКОРИСТАННЯМ ВІРТУАЛЬНОГО КАБІНЕТУ ФІЗИКИ}

ORCID ID: 0000-0002-5790-7792

вчитель фрізики та інформатики ${ }^{1}$,
аспірант кафедри теорії та методики навчання фрізики та астрономії ${ }^{1} H В K$ «Домінанта»

${ }^{2}$ Національний педагогічний університет імені М.П. Драгоманова

Науковий керівник: Благодаренко Людмила Юріївна

доктор педагогічних наук, професор, професор кафедри загальної та прикладної фрізики Національний педагогічний університет імені М.П. Драгоманова УКРАЇНА

Нині в усіх сфрерах діяльності все вагомішим стає вплив інформаційнокомунікаційних технологій (IKT). Особливого значення інформатизація і комп'ютеризація набувають в системі середньої освіти відповідно до концепції нової української школи. І у більшій мірі це стосується природничої освіти, оскільки формування перспективної та інтелектуально-творчої особистості залежить, насамперед, від розуміння нею сучасної картини світу. Оскільки провідне місце в системі природничих наук належить фізиці, яка є основою таких сучасних напрямів досліджень, як космологія, біофізика, робототехніка, космічне моделювання тощо, то використання інформаційно-комунікаційних технологій в навчанні фрізики забезпечить нові можливості для забезпечення його якості.

Зрозуміло, що в контексті всебічної глобалізації, яка перетворює світ на єдиний простір, вивчення фізики не можна обмежити використанням лише традиційних засобів навчання. Тому вчитель повинен подолати цей бар'єр і забезпечити для учнів можливість отримання знань в умовах використання інформаційно-комунікаційних технологій. А для цього необхідно створити відповідне навчальне середовище. Функціонування комп'ютерно орієнтованого навчального середовища забезпечує поєднання можливостей кабінету фрізики, інтерактивних технологій та віртуального моделювання. В результаті такого поєднання формується віртуальне навчально-інформаційне середовище - віртуальний кабінет фізики (ВКФ).

Використання віртуального кабінету фрізики вимагає від учителя достатнього рівня комп'ютерної грамотності та наявності психологопедагогічних і методичних знань. Володіючи відповідними уміннями та навичками, учитель фрізики буде здатний самостійно створювати навчальні електронні матеріали, адже саме вони відображають його бачення щодо викладання предмета і дають можливість формувати базу педагогічного досвіду, що, у свою чергу, сприятиме самовдосконаленню фахівця. Розробляючи власні електронні продукти, використовуючи наявні продукти та можливості навчального закладу, вчитель завжди зможе обрати певну модель побудови навчального середовища відповідно до особливостей учнівського колективу та освітньої підготовки кожного учня $[1,2]$. 
Аналіз літературних джерел з проблеми дослідження свідчить про те, що існують різні моделі використання засобів ІКТ, які набули поширення у закладах середньої освіти [3]. Нами запропоновано нову модель, яка інтегрується у навчально-інформаційне середовище «Віртуальний кабінет фрізики» і $є$ основою для організації навчання учнів з використанням технологій віртуального кабінету фрізики (рис. 1). В умовах фрункціонування такої моделі необхідна наявність гаджета з підключенням до мережі Internet, що на сьогоднішній день забезпечує використання мобільних телефонів. Учень протягом навчального року може навчатись за однією з двох схем: учень кабінет фізики; учень - віртуальний кабінет фрізики. При цьому обидва процеси можна поєднати, а робота за будь-якою схемою та їх поєднання здійснюється під керівництвом вчителя. Технології віртуального кабінету використовують для послідовного і безперервного опанування навчального матеріалу. Поперше, це дає можливість вчителю (не виходячи зі школи) провести навчання відповідно до календарного (поурочного) плану. По-друге, учень отримує своєчасну якісну, технологічно підготовлену освітню послугу.

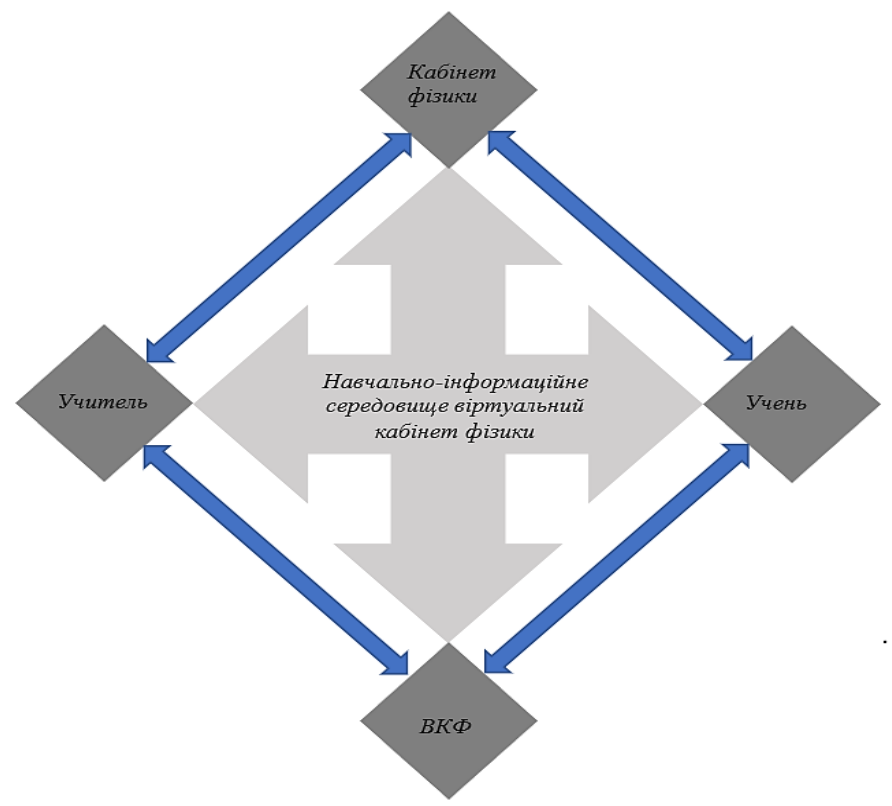

Рис. 1. Модель навчально-інформаційного середовища «Віртуальний кабінет фрізики»,

Важливою перевагою запропонованої нами моделі $є$ те, що описані вище етапи освітнього процесу реалізуються в умовах як замкненого навчального середовища - в закладі середньої освіти, так й відкритого навчального середовища. Очевидно, що на відміну від інших форм навчання, використання віртуального кабінету фрізики поєднує кращі традиції класно-урочного навчання та можливості відкритої освіти. Зрозуміло, що крім всіх очевидних переваг, 
використання віртуального кабінету фізики має і свої недоліки, серед яких основним $€$ наявність апаратних, програмних і мережних збоїв інформаційних технологій.

Основна діяльність вчителя за умов використання віртуального кабінету фізики полягає в організації й управлінні навчально-виховним процесом online, створенні та оновленні матеріалів уроків, візуалізаційних моделей, тестів, текстових дидактичних матеріалів. Виділимо основні форми взаємодії вчителя й учня з використанням віртуального кабінету фізики. Віртуальний кабінет дає вчителю можливість індивідуалізувати освітній процес, тобто працювати 3 одним учнем - проводити опитування, тестування, прослуховувати відповіді або розглядати їх у письмовому вигляді. Друга форма відтворює роботу учителя з класом. Учні й учитель мають одночасний доступ до навчального середовище через сайт віртуального кабінету фізики, який відображається у кожного на екрані. Вчитель керує навчальним процесом, передає права спілкування учням по черзі, проводить опитування, тестування, вислуховує відповіді тощо. Особливість такої форми полягає у чіткій координації - кому передати права, що повинні робити учні тощо. За цією формою керування навчальним процесом доцільно проводити бінарні уроки, що будуть демонструвати міжпредметні зв'язки. Вчителі по черзі або паралельно працюють з класом. Така форма вимагає розроблення чіткої поетапної схеми уроку. Вчителі планують урок таким чином, щоб на сайті віртуального кабінету фізики були завдання з обох предметів, а учні, використовуючи віртуальний кабінет фізики, мали можливість працювати паралельно.

Віртуальний кабінет фізики також забезпечує для вчителів можливість розширення меж класно-урочного навчання як з обдарованими учнями, так і 3 тими, які з тих або інших причин не відвідують школу. Робота з обдарованою молоддю дозволяє організовувати передзахист робіт Малої Академії наук, роботу круглих столів, дискусійних клубів, гуртків, різноманітних позакласних заходів.

Отже, виходячи із можливостей сучасних веб-серверів, сучасних сервісів, Інтернет-технологій, ми пропонуємо для організації навчального процесу 3 фізики структурно-функціональну модель використання віртуального кабінету фізики, яка буде найбільш ефективною за умов її системної реалізації. Слід відзначити, що для успішного функціонування віртуального кабінету фрізики важливими є додаткові компоненти - такі електронні засоби навчального призначення, як Е-тести, Е-книги, відео, аудіо, віртуальні моделі, віртуальні лабораторні-досліди та інші. Призначення цих компонентів полягає у виявленні рівня знань учнів, а також у закріпленні умінь і навичок, отриманих під час навчання в умовах віртуального кабінету фізики. Також у використанні технологій віртуального кабінету тією чи іншою мірою відіграють роль елементи електронного простору, оскільки вони сприяють тісній взаємодії учнів та вчителя, обміну інформацією, швидкому поширенню відомостей тощо.

Нами запропоновано алгоритм використання віртуального кабінету фізики:

- учитель розробляє дидактичні матеріали для учня (презентації, схеми, моделі, посилання на сайти інститутів тощо) та розміщує їх на сайті віртуального кабінету фрізики;

- учитель вказує час та тривалість виконання завдань, тему уроку, відмічає засоби взаємодії (аудіо, відео); 

уроку;

- учитель використовує технології віртуального кабінету для проведення

- оцінювання учня здійснюється як усно, так і з використанням завдань у віртуальному кабінеті фрізики.

Таким чином, переваги використання віртуального кабінету фізики $є$ очевидними: можливість навчатися дистанційно; отримання додаткових знань з ресурсів глобальної мережі Internet (учитель підготовлює сайти з такими ресурсами), платформами дистанційного навчання та іншими пакетами прикладних програм; індивідуальне навчання; навчання у малих групах; присутність на уроках вчителів інших шкіл; більша зосередженість учня; візуальні контакти з однолітками; контроль виконання завдань online; перегляд навчальних відеофільмів; використання готових презентацій; інтерактивні відповіді - використання Smart-елементів; можливість завантаження матеріалів у навчальне середовище як вчителем, так і учнем; проведення спільних уроків з батьками; демонстрація власних дослідів; розширення можливостей учнів під час підготовки до підсумкових робіт, тестування (отримання зразків завдань, які будуть на тематичному тестуванні); тестування як навчання; розвиток вмінь навчатися самостійно і здобувати знання з різних джерел; відвідування уроків у online-режимі.

\section{Список використаних джерел:}

1. Шут, М. І., Благодаренко, Л. Ю. (2109). Підготовка вчителя фізики в Україні: як зберепи її в умовах кризи природничої освіти Матеріали VII Міжнародної науково-практичної конфреренції «Науково-дослідна робота в системі підготовки фрахівців-педагогів у природничій, технологічній і комп'ютерній галузях» (с. 15-17). Бердянськ, Україна: БДПУ.

2. Банак, Р. Д. (2019). Віртуалізація навчального процесу з фізики. Фізика та Астрономія в рідній школі (145) 37-41.

3. Жук, Ю. О. \& Соколюк, О. М. (2005). Характерні ознаки структури комп'ютерно орієнтованого навчального середовища. Інформаційні технології і засоби навчання, 100-108.

\section{ПОЛІТИКА БЕЗПЕКИ ВЕБ-РЕСУРСІВ}

Розломій Інна Олександрівна канд. техн. наук, викладач кафедри інформаційних технологій Черкаський національний університет ім. Б. Хмельницького

УКРÄ̈HA

В умовах постійного збільшення кількості веб-додатків та інформаційних систем підвищується необхідність надійного захисту даних. Втрата інформації може призвести до непоправних наслідків для діяльності будь-якої організації, бізнесових структур. Одним з найважливіших моментів інформаційної безпеки $€$ надійна аутентифікація користувача з метою отримання доступу до свого акаунта на тому чи іншому веб-ресурсі.

Сучасні веб-ресурси містять в собі велику кількість функціоналу, який порізному доступний користувачам. Тому, основна проблема полягає в 
забезпеченні можливості, щоб система розпізнавала користувачів і у відповідності з цим надавала той чи інший функціонал. Безпека процедури входу для користувачів в основній більшості визначає захищеність інформаційної системи в цілому. Процедура входу в систему включає три етапи: ідентифікацію, аутентифікацію, авторизацію [1]. Етап аутентифікації забезпечує підтвердження достовірності суб'єкта і є найважливішим, тому цю процедуру необхідно реалізувати максимально безпечною.

Одним 3 найпоширеніших способів аутентифікації $€$ парольна аутентифікація. Використання пароля в якості аутентифікаційного фактору ще тривалий час буде найрозповсюдженішим способом вирішення задач підтвердження достовірності, насамперед, це пов'язано з простотою реалізації і низькими витратами.

В парольних системах аутентифікації можуть використовуватись одноразові та багаторазові - статичні паролі. Попри недоліки багаторазових паролів [2], вони все ж продовжують використовуватись в веб-ресурсах. Надійності статичного паролю захисту можна досягти за рахунок задання його стійкості.

При виборі паролів користувачі системи (веб-сайту) мають керуватися двома взаємовиключними правилами - паролі мають складно підбиратись і легко запам'ятовуватись [3, с. 87]. Але, оскільки правила взаємовиключні то паролі, зазвичай, прості і дуже легко підбираються. Складність підбору пароля визначається, в першу чергу, потужністю множини символів, яка використовується при виборі паролю (M) і максимально можливою довжиною пароля (k). В цьому випадку, максимально можлива кількість різних паролів обчислюється за формулою $P=M^{k}$. Наприклад, якщо пароль створюється 3 множини малих літер латинського алфавіту, а мінімальна довжина паролю рівна 4 символам, то кількість паролів буде рівна $P=M^{k}=26^{4}=456976$, що зовсім мало для програмного підбору. Якщо розширити множину можливих символів - додати великі літери та цифри, а також збільшити довжину пароля до 5 символів, то кількість варіантів пароля буде рівна $P=M^{k}=62^{5}=916132832$.

Складність паролів, які можуть обирати користувачі, має встановлюватись адміністратором при реалізації установленої для системи політики безпеки. До параметрів інших параметрів політики облікових записів при парольній аутентифікації відносяться: максимальний термін дії пароля; неспівпадання пароля з логічним іменем користувача, під яким він зареєстрований в системі; паролі одного користувача не повторюються [4]. Для того, щоб системі протидіяти спробам підбору паролів необхідно використовувати правила:

1. Протидія підбору пароля автоматизованим способом. В сучасних вебдодатках для протидії автоматизованим спробам підбору пароля використовують технологію Captcha.

2. Обмеження кількості спроб входу в систему. Для обмеження кількості спроб входу в систему використовують фільтр активності, в якому присутні налаштування параметрів блокування доступу до веб-сайту при перевищенні ліміту активності від певного користувача.

3. Приховування логічного імені користувача, який останній працював 3 системою. На рівні системи не має сенсу забезпечувати, оскільки підстановку логічного імені користувача більшість браузерів виконує за замовченням. 
4. Облік успішних та неуспішних спроб входу в систему. Облік всіх спроб входу в систему забезпечується вбудованим журналом подій.

На разі це не єдині способи протидії підбору паролів. На невдалу спробу входу система може реагувати таким чином: блокування облікового запису при перевищенні максимально можливої кількості спроб входу; наростаюче збільшення часової затримки перед наданні користувачу наступної спроби входу.

Висновки. Таким чином, в статті було розглянуто основні принципи політики безпеки веб-ресурсів. Основна увага зосереджена на парольній аутентифікації користувачів, зокрема парольна аутентифікація на використанні статичних паролів. Запропоновано спосіб підвищення надійності паролю за рахунок задання його стійкості. Розглянуто параметри політики облікових записів при парольній аутентифрікації, а також описано правила протидії спробам підбору паролів та реакцію системи на невдалі спроби входу.

\section{Список використаних джерел:}

1. Сабанов, А. Г. (2011). Аутентификация при электронном обмене документами. Доклады Томского государственного университета систем управления и радиоэлектроники, (2), 263-266.

2. Алешников, С. И., Демин, С. А., Федоров, С. Б. (2013). Проблемы информационной безопасности организации (предприятия) и пути их решения. Вестник Балтийского федерального университета им.И.Канта, (1), 147-154.

3. Паутов, П. А. (2008). Проблема аутентификации в многоуровневых приложениях. Прикладная дискретная математика, (2), 87-90.

4. Сабанов, А. Г. (2013). Методы исследования надежности удаленной аутентификации. Электросвязь, (4), 263-267.

\section{РЕКУРЕНТНІ НЕЙРОННІ МЕРЕЖІ ТА ДОВГА КОРОТКОЧАСНА ПАМ'ЯТЬ}

Тимофєєва Анастасія Євгенівна здобувач вищої освіти математичного факультету Запорізький національний університет УКРАÏHA

Рекурентні нейронні мережі (РНМ) були названі так тому, що вони виконують одну й ту ж задачу для кожного елементу послідовності, причому вихідні дані залежать від попередніх обчислень. На відміну від «звичайних» нейромереж, або ж нейромереж прямого поширення (англ. feed-forward neural networks), в яких інформація передається тільки вперед по мережі, від шару до шару. Ще одна інтерпретація PHМ: це мережі, у яких є «пам'ять», яка враховує попередню інформацію.

Одна з головних областей застосування РНМ на сьогоднішній день робота з мовними моделями, зокрема - аналіз контексту і загального зв'язку слів в тексті. Для РНМ структура мови - це довгострокова інформація, яку треба запам'ятати. До неї відносяться граматика, а також стилістичні 
особливості того корпусу текстів, на яких проводиться навчання. Фактично PHC запам'ятовує, в якому порядку зазвичай йдуть слова і може дописати речення.

Найбільш часто використовуваним типом PHM є LSTM (англ. Long shortterm memory; LSTM), які набагато краще зберігають довгострокові залежності, ніж PHM. Принцип LSTM-мереж схожий на принцип класичних PHM, але кожна клітина виконує більше операцій, що дозволяє їм запам'ятовувати довготривалі залежності.

Усі рекурентні нейронні мережі мають форму ланцюга повторюваних модулів нейронної мережі. LSTM теж мають таку ланцюгову структуру, але повторюваний модуль має іншу будову. Замість одного нейронного шару їх чотири, причому вони взаємодіють особливим чином.

Першим кроком в LSTM потрібно вирішити, якої інформації ми збираємося позбутися з клітинного стану. За даний процес відповідає «забуваючий шар» (англ. «forget gate layer»).

На наступному кроці необхідно вирішити, яку нову інформацію ми збираємося зберегти в клітинному стані. Цей крок складається з двох частин. По-перше, сігмоїдний шар, що називається «вхідним шаром» (англ. «input gate layer»), вирішує, які значення ми оновимо. Далі шар гірпеболічного тангенса створює вектор кандидатів на нові значення, який може бути доданий до стану. На наступному кроці ми з'єднаємо ці дві частини, щоб створити оновлення для стану.

Нарешті, для визначення виходу ми використовуємо сігмоїдний шар, який вирішує, які частини клітинного стану ми збираємося відправити на вихід. Потім ми пропускаємо клітинний стан крізь гіперболічний тангенс (щоб вмістити значення в проміжок від 1 до -1) і множимо його на вихід сігмоїдного шару (англ. «оutput gate layer»).

Рекурентні нейронні мережі продемонстрували великий успіх у багатьох задачах NLP (в обробці природної мови). Використовуючи двосторонню РНМ разом з LSTM-комірками, можна добре передбачати послідовності. А якщо об'єднати їх з механізмом уваги, то вийде сучасна модель машинного перекладу, аналізу тональності тексту та ін.

\section{Список використаних джерел:}

1. A Beginner's Guide to LSTMs. Retrieved from https://skymind.ai/wiki//stm\#long.

2. An Overview of Deep Learning for Curious People. Retrieved from https://lilianweng.github.io/lillog/2017/06/21/an-overview-of-deep-learning.html\#recurrent-neural-network. 


\title{
SECTION IV. \\ PHYSICS AND MATHEMATICS
}

\section{ТЕХНОЛОГІЯ ПРОБЛЕМНОГО НАВЧАННЯ ТА ЇІ ЗАСТОСУВАННЯ НА УРОКАХ МАТЕМАТИКИ}

\author{
Рудікевич Світлана Юріївна \\ вчитель математики, вища категорія \\ Черкаська загальноосвітня школа I-III ступенів № 25 \\ Черкаської міської ради Черкаської області
}

УКРАÏHA

Загальноосвітній простір України є цілісною динамічною системою, що йде в ногу з часом, постійно оновлюючись. Сучасний етап розвитку шкільної освіти відзначається зміною ролі вчителя та підходу до учнів, появою нових вимог до проведення планових (позапланових) заходів. Але головною її особливістює формування самостійної діяльності учнів: вчитель перестає бути передавачем знань у готовому вигляді, він стає організатором процесу їх отримання. Допоміжним засобом досягнення максимального результату при такій побудові уроку є новітні освітні технології. На уроках математики найдієвішою виступає саме технологія проблемного навчання.

Авторка відповідного дослідження поставила за мету здійснити поглиблений аналіз змісту та ролі технології проблемного навчання в підвищенні ефективності процесу засвоєння учнями навчального матеріалу на уроках математики.

Об'єктом вивчення стала проблема оптимізації освіти.

Предметом наукового дослідження виступає технологія проблемного навчання та їі застосування на уроках математики.

Історіографічна база окресленої проблеми $€$ досить широкою. Серед дослідників, які вивчали питання застосування технології проблемного навчання на уроках математики, слід відзначити роботи В. А. Кушнір [1], О. М. Ліби [2], О. Ю. Орєхової [3], Я. С. Цимбалюк [4], Я. В. Шмулян [5]. Втім, не всі аспекти проблеми знайшли достатнє відображення в наукових студіях, тому необхідність їі подальшого поглибленого вивчення залишається актуальною.

Технологією проблемного навчання називають створену вчителем проблемну ситуацію з направленням учнів на шлях її успішного розв'язання. У такий спосіб він залучає учнів до процесу мислення, тобто підводить їх до необхідності аналізу, синтезу, систематизації, порівняння та узагальнення фактів і явищ. У такий спосіб вчитель спонукає учнів до творчого мислення та пошуку неординарного рішення поставленого перед ними завдання [4].

Для відповідного методу викладання характерним $є$ запропоноване вчителем завдання, з прихованими можливими індивідуально-пізнавальними розбіжностями, та самостійне його вирішення учнями. Йдеться про постановку вчителем проблеми, яку необхідно вирішити в ході дослідження; гіпотези, які 
пропонують учні як можливе її розв'язання; перевірку останніх й створення на їх основі висновків. Якщо зазначати про саму проблему, то варто наголосити, що фрорма її вираження має бути найбільш універсальною та ефективною [3].

Виникає логічне запитання: «Чи можна навчати так, щоб кожен учень самостійно шукав правильне рішення окресленого вчителем завдання, але при потребі зміг зіставити свою думку з поглядами однокласників?». Так. Застосування вчителем проблемного методу навчання надає таку можливість, адже створення проблемної ситуації на уроці допомагає учням розкритися і якомога краще розвивати свій творчий потенціал [1; 5].

Тож, застосування на уроках математики технології проблемного навчання забезпечує: засвоєння учнями найважливіших ідей математики; опанування ними системою основних наукових понять; вміння орієнтуватися в навчальнонауковій літературі, самостійно знаходячи потрібну інформацію; активізацію їх творчих здібностей [2].

Розглянемо типовий приклад проблемної ситуації під час навчання математики в загальноосвітній школі. Зокрема, чи вірно наведено порівняння: $78,2>78,123$ ? Інколи учні дають відповідь, що «невірно». Однак, дана нерівність справедлива, тому вчитель математики звертається до учнів із питанням: «Чому число, що складається з більшого числа розрядів, менше числа, що складається з меншого числа розрядів?». Лише після невдалих роздумів учнів над виходом із ситуації, вчитель пропонує останнім подивитись на порівняння з іншої точки зору, тим самим наводячи їх на правильне розв'язання запропонованого ним прикладу.

Щоб мінімізувати подібні моменти на уроці, вчителю математики варто надавати учням такі завдання, які мали б викликати в них труднощі, проте одночасно бути посильними для самостійного пошуку відповіді [3-4].

Висновки. Проблемний виклад навчального матеріалу сприяє не лише розвитку інтелектуальних умінь і навичок, але й пізнавальній активності учнів. Велике значення для активізації їх пізнавальної діяльності на уроках математики мають саме проблемні завдання. Тут, головна роль вчителя полягає в тому, щоб учні сприйняли запропоновані ним завдання як проблему та самостійно її вирішили. Постановка перед учнями посильного для них проблемного завдання та здійснення вчителем у разі потреби допомоги в його розв'язанні - головне у процесі навчання математики.

\section{Список використаних джерел:}

1. Кушнір, В. А., Кушнір Г. А. \& Ріжняк, Р. Я. (2008). Інноваційні методи навчання математики. Кіровоград.

2. Ліба, О. М. \& Біла, М. М. (2016). Наука та освіта: актуальні проблеми досліджень на сучасному етаnі: Тези Всеукраїнської науково-практичної конференції (с. 125-128). Мукачево, Україна.

3. Орєхова, О. Ю. Застосування проблемного навчання на уроках математики. Вилучено 3 http://ped-kopilka.com.ua/hitelam-/matematika.

4. Цимбалюк, Я. С. (2008). Актуальні проблеми методики навчання математики: Тези Регіональної науково-практичної конференції (сс. 128-136). Одеса, Україна.

5. Шмулян, Я. В. Використання проблемних методів на уроках математики в основній школі. Вилучено з http://konferenzia.ukrainianform.net/t12-topi. 


\section{SECTION V.} BIOLOGY

\section{FATTY ACID COMPOSITION OF CITRUS OILS}

Osyp Yu.L. Associate Professor of the Department of Organic Chemistry and Pharmacy, Lesya Ukrainka Eastern European National University

Osyp M.A.

Teacher of the First Category Lutsk Pedagogical College

UKRAINE

Цитрусові рослини містять багато корисних для людського організму речовин та мають чудові смакові якості. Вважається, що на плоди цитрусових на світовому ринку припадає більше третини всіх споживних свіжих фруктів [1]. Порівняння вмісту біологічно активних речовин в цитрусових $є$ важливим для більш ефективного використання цих плодів у харчовій, фармацевтичній та косметичній промисловості.

Насіння ізолювали з спілих фруктів, сушили протягом місяця у темному місці при кімнатній температурі, подрібнювали та використовували для отримання олії.

Методом вичерпної екстракції н-гексаном у апараті Сикслета було встановлено, що у насіння лимонів містить $66 \%$ жирної олії, насіння апельсинів - $52 \%$, насіння мандаринів - 34\% та насіння грейпфрутів $25 \%$.

Аналіз жирнокислотного складу досліджуваних олій проводили методом високоефективної газорідинної хроматографії на хроматографрі «Кристалл 2000м» 3 капілярною колонкою DB-FFAP (США) та полум'яно- іонізаційним детектором відповідно до методики наведеної у ГОСТ 30418-96 [2].

Результати досліджень (у \%) представлені у таблиці 1:

\begin{tabular}{|l|c|c|c|c|}
\hline Жирні кислоти/Олія & $\begin{array}{c}\text { Олія 3 } \\
\text { насіння } \\
\text { лимонів }\end{array}$ & $\begin{array}{c}\text { Олія 3 } \\
\text { насіння } \\
\text { апельсинів }\end{array}$ & $\begin{array}{c}\text { Олія 3 } \\
\text { насіння } \\
\text { мандаринів }\end{array}$ & $\begin{array}{c}\text { Олія 3 } \\
\text { насіння } \\
\text { грейпфрутів }\end{array}$ \\
\hline Пальмітинова С16:0 & 24,0 & 39,9 & 28,8 & 32,3 \\
\hline Стеаринова С18:0 & 2,8 & 5,0 & 3,4 & 2,4 \\
\hline Олеїнова С18:1 & 29,0 & 24,2 & 22,0 & 19,6 \\
\hline Лінолева С18:2 & 36,4 & 29,9 & 43,2 & 41,1 \\
\hline Ліноленова С18:3 & 7,8 & 1,0 & 2,7 & 4,6 \\
\hline
\end{tabular}

Досліджувані олії мають однаковий якісний склад жирних кислот та схоже їх співвідношення, що може свідчити про їх спільне походження (сімейство Рутових, родина Цитрусові).

Загалом у жирнокислотному складі усіх досліджуваних оліях переважають ненасичені жирні кислоти, що представлені олеїновою $(\omega-9)$, лінолевою $(\omega-6)$ 
та ліноленовою кислотами ( $\omega$-3). Ці кислоти відносять до незамінних, так як вони не синтезуються в організмі людини, але необхідні для нормального його функціонування [3,4]. Вміст лінолевої кислоти складає від 29,9 \% у олії насіння апельсинів до 43,2 \% у олії насіння мандаринів. Особливо цінними вважаються жирні кислоти $\omega-3$, які знижують ризик розвитку серцево-судинних захворювань [5,6]. Згідно отриманих результатів ліноленової кислоти найменше у олій насіння апельсинів (близько 1 \%) та мандаринів (2,7 \%), дещо більше її в олії насіння грейпфрута (4,6 \%). Найбільше ліноленової кислоти міститься в олії насіння лимона, де її вміст сягає 7,8 \%. Крім того олія лимону містить найбільшу загальну кількість ненасичених жирних кислот (76 \%), а їі вихід є найбільшим серед досліджуваних олій, тому, на нашу думку, ця олія є найбільш перспективна для народного господарства.

\title{
Список використаних джерел:
}

1. Слюсарів, А. О., Самсонов, О. В. \& Мухін. В.М. (1995). Біологія, (2-е вид.). В. О. Мотузенов (ред.). Київ: Вища школа.

2. Метод определения жирнокислотного состава: ГОСТ 30418-96. (1996). Минск: Межгосударственный совет по стандартизации, метрологии и сертификации.

3. Шеманська, Є. І. (2012). Склад і біологічна цінність олій холодного пресування. Вісник Донецького національного університету економіки і торгівлі імені Михайла ТуганБарановського Науковий журнал, (1).

4. Барбай, В. А., Брехман, И. И., Голотин, В. Г. \& Кудряшев, Ю. В. (1992). Перекисное сопротивление и стресс. СПб.: Наука.

\section{ЕКОЛОГІЧНИЙ АНАЛІЗ ТА ОЦІНКА СТІЙКОСТІ ДЕНДРОФЛОРИ ТОМИЛІВСЬКОГО ПАРКУ}

\author{
Левандовська Світлана Миколаївна \\ канд. біол. наук, доцент \\ Білоцерківський національний аграрний університет \\ УКРӒ̈HA
}

Важливою складовою природно-заповідного фонду України є паркипам'ятки садово-паркового мистецтва (далі ППСПМ), стан рослинності у яких заслуговує особливої уваги з естетичного, екологічного та господарського погляду. Водночас ППСПМ відіграють значну наукову, виховну та оздоровчу роль, є місцем рекреації і туризму. Одним з таких об'єктів є парк-пам'ятка садово-паркового мистецтва місцевого значення «Томилівський» площею 2,8 га, розташований у межах ДП «Білоцерківське лісове господарство». Детальні відомості щодо історії створення парку-пам'ятки та спеціально опубліковані зведення стосовно його дендрофлори відсутні. Відомо, що парк був закладений у 50-х pp. XX ст. на честь Перемоги у Великій Вітчизняній війні. Основою парку була стара ялинова алея. Рішенням виконавчого комітету Київської області ради народних депутатів від 28.02.1972 р. № 118 «Про 
віднесення пам'яток природи місцевого значення за категоріями, згідно нової класифікації та затвердження нововиявлених заповідних територій i природних об'єктів в області» парку «Томилівський» надано статусу заповідного об'єкту. Зважаючи на вищезазначене, дослідження щодо сучасного видового складу та стану дендрофлори Томилівського парку $є$ актуальними.

В результаті інвентаризаційних досліджень виявили, що до складу деревно-чагарникових насаджень ППСПМ входить 217 таксонів. Вони представлені 209 видами і 8 формами, які належать до 97 родів, 41 родини, 30 порядків, трьох класів (Pinopsida, Ginkgopsida, Magnoliopsida) та відділів Pinophyta i Magnoliophyta.

Серед основних абіотичних чинників, що впливають на життєдіяльність рослин визначальними $€$ світло, вода, трофнність ґрунту, тепло. За відношенням до світла види рослин розподілено на три екогрупи: геліофіти, гемісціофіти, сціофіти [2]. В екологічній структурі дендрофрлори ППСПМ «Томилівський» переважна більшість таксонів є вибагливими до інтенсивності освітлення (117, 53,9 \%). До екогрупи геліофітів належать: Ginkgo biloba L., Pseudotsuga menziesii (Mirb.) Franco, Larix decidua Mill, Pinus banksiana Lamb., Juniperus horizontalis Moench., Forsythia europae Deg. et Bald., Catalpa speciosa Warder ex Engelm., Armeniaca vulgaris Lam. та інші. Гемісціофріти складають наступну за чисельністю групу - 88 таксонів $(40,6 \%)$ - Pinus austriaca Hull., Pinus strobus L., Juglans regia L., Aesculus hippocastanum L., Pterocarya pterocarpa (Michx.) Kunth et Jljinsk. та інші. Найменш вимогливі (сціофіти) складають 5,5 \% (Thuja occidentalis, Picea pungens Engelm., Chamaecyparis lausoniana Parl. та інші).

Для розподілу дендрофлори ППСПМ за відношенням до вологи та трофрності грунту використовували оптимізовані шкали М. М. Матвєєва [1]. Результати аналізу за вибагливістю до умов зволоження засвідчують, що переважаючою групою рослин у дендрофрлорі ППСПМ $є$ мезофіти. Виділена група охоплює 102 таксони (47,0%), зокрема: Ginkgo biloba L., Larix decidua Mill., Viburnum opulus L., Cornus mas L., Cerasus avium (L.) Moench, Crataegus pentagynaWaldst. et Kit., Carpinus betulus L., Salix viminalis L., Hedera helix L. та інші. Друге місце належить групі ксерофітів - 96 таксонів $(44,2$ $\%$ ) (Pinus cembra L., Picea glauca Moench., Juniperus communis L., Malus niedzwetzkyana Dieck ex Koehne, Caragana frutex (L.) C. Koch., Cotinus coggygria Scop., Fraxinus lanceolata Borkh. та інші). Незначна кількість таксонів (19 видів, 8,8 \%) належить до гігрофітів - Betula obscura A. Kotula., Alnus glutinosa (L.) Gaertn., Alnus incana (L.) Moench, Phellodendron amurense Rupr. та інші.

За вимогливістю до вмісту поживних речовин у ґрунті рослини поділяють на три основні екологічні групи: мегатрофи, мезотрофи та оліготрофи. Серед досліджених таксонів переважають мезотрофи (95, 43,8 \%), а саме: Pseudotsuga menziesii (Mirb.) Franco, Ginkgo biloba L., Larix decidua Mill., Larix polonica Racib., Catalpa bignonioides Walt., Quercus palustris Moench та інші. Майже однакову кількість з мезотрофами складають оліготрофи (91 таксон, 41,9 \%) - Pinus sylvestris L., Pinus banksiana Lamb., Pinus rigida Mill., Juniperus communis L., Juniperus virginiata L. Thuja occidentalis L., Amelanchier 
ovalis Medik. Найменшу кількість (31 таксон, 14,3 \%) складають мегатрофи, які потребують для росту і розвитку багаті на гумус і мінеральні речовини ґрунти. Із них відзначимо: Thuja plicata D. Don., Vitis vinifera L., Juglans regia L., Buxus sempervirens L. та інші.

Основним показником успішного росту рослин у нових умовах інтродукції $\epsilon$ їх зимо- та посухостійкість. Зимостійкість - це властивість рослин витримувати низьку температуру повітря протягом тривалого періоду. Для оцінки зимостійкості використали 8-бальну шкалу С.Я. Соколова [3]. Візуальні спостереження показали, що у дендрофлорі ППСПМ «Томилівський» переважає група цілком зимостійких таксонів (0, рідко I бал), які зимують без пошкоджень. Їх нараховуємо 122 (56,2%) - Picea glauca Moench., Picea pungens Engelm., Pinus strobus L., Berberis vulgaris L., Quercus robur L., Ulmus laevis Pall. та інші. Обмерзання однорічних пагонів (II, III бали) спостерігали у рослин 83 таксонів (38,2 \%) - Buxus sempervirens L., Viburnum opulus L., Lonicera tatarica L., Juglans regia L. Назначною кількістю (12 таксонів, 5,5 \%) у дослідженій дендрофрлорі представлені недостатньо зимостійкі види (IV бали) - Deutzia scabra Thunb., Armeniaca vulgaris Lam. та ін. Посухостійкість видів деревних рослин оцінювали за п'ятибальною шкалою Пятницького С.С. [2]. Проаналізувавши дендрофрлору ППСПМ «Томилівський» за критерієм посухостійкості встановлено, що серед дерев і чагарників переважають таксони (161, 74,2 \%), які здатні витримувати нетривалі посухи. За відповідною шкалою їх оцінено у п'ять балів (Picea abies (L.) Karst., Juniperus foetidissima Willd., Sorbus torminalis (L.) Crantz.). Меншу частку (56 таксонів) становлять відносно посухостійкі таксони (чотири бали), їх життєздатність продовжується навіть при значних втратах вологи. До цієї екогрупи належать: Larix decidua Mill., Fraxinus excelsior L., Berberis iliensis Popof та інші.

Таким чином, результати екологічного аналізу свідчать про високу адаптивність переважної більшості таксонів дендрофлори ППСПМ «Томилівський» до кліматичних умов регіону досліджень, яка виявляється у переважанні цілком зимостійких та з високим показником посухостійкості таксонів, помірно вимогливих до освітлення, вологості й родючості ґрунту.

\section{Список використаних джерел:}

1. Матвеев, Н. М. (2003). Оптимизация системы екоморф растений А. Л. Бельгарда в целях фитоиндикации экотопа и биотопа. Вісник Дніпропетровського університету (Т. 2.: Серія: Біологія, екологія), (11), 105-113.

2. Пятницкий, С. С. (1961). Практикум по лесной селекции. Москва.

3. Соколов, С. Я. (1957). Современное состояние теории акклиматизации и интродукции растений. Интродукция растений и зеленое строительство: труды Ботан. ин-та АН CCCP, 6(5), 34-42. 
NOTES 


\section{ペOГО}

COLLECTION OF SCIENTIFIC PAPERS

\section{WITH PROCEEDINGS OF THE INTERNATIONAL SCIENTIFIC AND PRACTICAL CONFERENCE \\ «SCIENTIFIC DISCOVERIES: PROJECTS, STRATEGIES AND DEVELOPMENT»}

October 25, 2019 • Edinburgh, Scotland, UK

\section{VOLUME 1}

\section{English, Ukrainian and German}

All papers have been reviewed

Organizing committee may not agree with the authors' point of view Authors are responsible for the correctness of the papers' text

Signed for publication 25.10.2019. Format 60×84/16

Offset Paper. The headset is Arial. Digital printing.

Conventionally printed sheets 7,09 .

Circulation: 100 copies.

Printed from the finished original layout.

Contact details of the organizing committee:

21037, Ukraine, Vinnytsia, Zodchykh str. 18, office 81

NGO European Scientific Platform

Tel.: +38 $0981948380 ;+380981956755$

E-mail: info@ukrlogos.in.ua

URL: www.ukrlogos.in.ua 